\title{
Coleção SOBRESCRITA
}

\section{ESCRITA NO ENSINO SUPERIOR}




\section{Coleção SOBRESCRITA}

\section{ESCRITA NO ENSINO SUPERIOR A singularidade em monografias, dissertações e teses}

SONIA ALMEIDA

Paulistana

$\sim$ Editora

São Paulo

2011 
(c) Sonia Almeida

prof.soniaalmeida@gmail.com

Coleção SOBRESCRITA

Coordenador: Prof. Dr. Valdir Heitor Barzotto

Editoração eletrônica e atualização ortográfica

Lino Raposo Moreira

linomoreira@linomoreira.com

Foto da capa: Ramarys

Grafia atualizada segundo o Acordo Ortográfico da Língua Portuguesa de 1990, vigente no Brasil a partir de janeiro de 2009.

Dados de Catalogação:

Biblioteca Central da Universidade Federal do Maranhão

Almeida, Sonia (Sonia Maria Corrêa Pereira Mugschl), 1956-

Escrita no ensino superior - a singularidade em monografias, dissertações e teses / Sonia Almeida. - São Paulo: Editora Paulistana, 2011. (Coleção Sobrescrita).

244 p.; $14 \times 21 \mathrm{~cm}$.

ISBN 978-85-99829-50-9

1. Linguagem - Educação - 2. Escrita - Ensino superior I. Título

CDD 400.41

CDU 81142 
A Jesus, toda a honra. 
A minha mãe e meu pai A Daniel, Priscila, Beatriz e Valentina Rafael, Rossana e Lara Danilo e Tirza

A minhas irmãs; tio Carló e tia Tetê A Raquel Pereira dos Santos, leitora deste meu exercício de escrita Aos meus da Áustria

Ao Professor Doutor Valdir Heitor Barzotto, orientador desta investigação

Aos Professores Doutores: Natalino Salgado, Claudia Riolfi, Antonio Joaquim Severino, Maria Lúcia Pessoa Sampaio, Idméa Semeghini-Siqueira, Beatriz Sabóia, Núbia Bonfim, Cibele Krause Lemke. Aos acadêmicos Doutor Lino Moreira e Doutor Jomar Moraes. Aos Professores Mestres, Marcos Catunda, Enio Sugiyama e Mariana Aparecida de Oliveira Ribeiro, à Pós-Graduanda Suelen da Igreja e à Superintendente da Fundação Sousândrade, Professora Mestra Regina Luna Aos amigos: Dra. Mahiba Mattar Rahbani de Souza Martins, Dulce Costa e Mercedes Pereira, Pastor Afonso Matos e Cristina Aboud Matos, Luciene Pereira, Marize Aranha, Pastor Henrique e Fátima Barroso, Pastor Luís, Pastor Lindomar, Maria Varlene, Goretti de Carvalho, Elaine Peixoto, Graça Faria, Felipe Faria, Ana Lúcia Rocha, Augusto Ângelo, Fátima Lopes e Marlene, Wicleice Fábio. À Igreja Maranata 
Para Otto Mugschl 
Senhor, que se nos abram os olhos.

Mateus, 20.33 


\section{Sumário}

APRESENTAÇÃO 17

EXPLICAÇÕES INICIAIS 23

Por que a singularidade é uma questão? 25

Por que escrita e não texto? 29

1. CONVERSA FRANCA SOBRE A ESCRITA NA UNIVERSIDADE BRASILEIRA 35

Linguagem e educação: quebrando cristais 39

Uma pesquisa entre outras no Brasil 42

Diálogo entre pesquisadores sobre a escrita no ensino superior 43

Espaços que têm priorizado o debate sobre escrita no ensino superior 46

2. CONCEITOS FUNDAMENTAIS PARA PENSAR A ESCRITA 51

3. LIÇÕES FUNDAMENTAIS PARA PENSAR A ESCRITA 59 
Lições do poço 61

Lições da manada 72

4. A ESCRITA NORMAL E AS CERTEZAS DO PESQUISADOR 77

Um dado da ciência normal na literatura 81

Por uma ciência criadora 85

Interferência do contexto sócio-histórico nas produções universitárias 86

5. PRODUÇÕES UNIVERSITÁRIAS ENTRE OUTRAS INSTÂNCIAS DA ESCRITA 91

Os determinantes da escrita normal na Universidade 95 Produções universitárias: por uma escrita do escrito 98 Os determinantes de uma escrita laborativa 101

6. O PESQUISADOR: UM SER SOCIAL SOB A ÓTICA DA FILOSOFIA 105

Ser social, linguagem, pesquisador e produção do novo conhecimento 114

Discurso, ideologia e inconsciente: interferências na produção 119

Produções universitárias e trabalho: a ideia de máquina enunciativa 121

Produção e singularidade: a expressão do uno 123

Produções universitárias como resultado de uma pesquisa plena de sentido 129

7. POR QUE PRODUZIMOS NA UNIVERSIDADE? 133

Episódio de pesquisa (I): conversa com um grupo de graduandos 135 
Episódio de pesquisa (II): conversa com pósgraduandos 141

Episódio de pesquisa (III): palavras de um pósgraduando 143

Episódio de pesquisa (Iv): marcas da centralidade do autor-citado na materialidade do discurso 146 Episódio de pesquisa (v): a dessimbolização das produções universitárias 156

8. MONOGRAFIAS: HÁ OUTRO CAMINHO? 161

Responsabilização do autor-citado 166

A construção do objeto 169

9. DISSERTAÇÃO DE MESTRADO: QUAL A SAÍDA? 181

Responsabilização do autor-citado 184

A construção do objeto 186

10. TESE DE DOUTORADO: PRECISAMOS MESMO DA ESTILIZAÇÃO? 195

Responsabilização do autor-citado 199

A construção do objeto 202

11. TUDO SE CRIA, NADA SE COPIA? 217

Escrita normal e escrita laborativa 223

Referências 233

Bibliografia complementar 238 
Apresentação 
Nada melhor para começar a apresentação do segundo livro da Coleção SOBRESCRITA do que o esclarecimento da própria autora, Sonia Almeida:

Esta publicação é sobre escrita. Mas não sobre texto. Porque não estamos nos referindo à produção textual, mas à produção de conhecimento, em virtude de um confronto necessário com o objeto das investigações: a singularidade nas produções universitárias.

Esse esclarecimento feito pela autora é bastante oportuno para apontar a diferença que um grupo de pesquisadores vem procurando construir ao estudar a produção universitária, como o leitor vai poder constatar em todo o livro.

Nada melhor, também, do que vivenciar este momento de grande apelo à publicação em companhia de um livro como o de Sônia Almeida, pois ele dedica-se a interrogar a que se destina um texto, tomado como escrita, produzido na universidade.

Com a disponibilização de trabalhos que fazem este tipo de questionamento esperamos que também os leitores passem a perguntar à produção contemporânea em que medida ela se justifica e merece circulação. Do mesmo modo, espera-se que aqueles que se dedicam aos estudos de graduação e pós-graduação interroguem-se sobre o que estão fazendo quando escrevem seus textos.

Com tais características este livro traduz bem a proposta da coleção e do grupo de pesquisadores que vem se dedicando ao estudo da leitura e da escrita para além da forma e da prescrição. Em primeiro lugar, é um estudo endereçado a quem está de algum modo incomodado pela escrita. Em segundo, cumpre com o objetivo de colocar em circulação reflexões que ultrapassem o propósito de verificar como um texto é articulado. 
As pesquisas realizadas nessa perspectiva perguntam se os textos correspondem a alguns princípios da escrita em ambiente de produção de conhecimento. Acredita-se que na universidade, mais que escrever e colocar em circulação um texto, este precisa justificar-se em função da novidade de seu aparecimento, bem como justificar o espaço e o tempo que ocupa na vida de quem escreve e de quem lê.

Levantar estas questões tem se tornado fundamental em tempos de valorização da quantificação e da produção de 'molduras' de textos para que seus conteúdos sejam tocados por interrogações que forcem uma diferença. Por mais que se alegue o contrário, quando se trata de avaliar a qualidade de um texto, hoje parece contar mais sua capacidade de redizer o que já está dito a partir de citações de autores convencionais do que buscar novas maneiras de refletir sobre o que foi lido e sobre a realidade pesquisada. Assim, mesmo quando se opta por uma avaliação qualitativa, é o quantitativo que predomina, já que critérios como redizer bem ou inscrever-se sem tensões em perspectivas consolidadas acabam por traduzir-se em uma soma, fazendo do trabalho considerado qualificado um trabalho a mais na legitimação do que está posto.

No entanto, além da crítica aos modos vigentes de avaliação de textos, o que se coloca neste livro é também a necessidade de responsabilização pela própria escrita por parte de quem escreve, já que não é muito produtivo apenas transferir o fardo para os processos de avaliação em abstrato. As pessoas a quem este livro está endereçado são convocadas a refletir sobre os produtos que recebem e sobre os produtos que sobrescrevem. Desse modo, elas são chamadas a se incluírem nos processos de avaliação de sua própria escrita, durante o período mesmo em que neles estão imersas.

E, como não podia deixar de ser para o tipo de pesquisa, a autora dá seu exemplo, fazendo um movimento de investigação 
sobre sua própria trajetória na busca de compreensão da escrita, da sua escrita. Almeida não deixa passar despercebidas as escritas dos autores que lê, dos autores cujos dados analisa, e do próprio orientador, que, compartilhando saudades, angústias e compromissos, é levado para junto do conceito que toma como fundamental: "a singularidade, algo que não depende de um jeito de dizer, mas de um fazer diante da vida".

É assim que, embora pareça que estamos todos sendo arrastados por um manancial de textos, em rodamoinhos sobre si, o livro indica processos de construção de pontos de sustentação, a partir de onde cada um pode construir sua própria sustentação na escrita e oferecer um terreno seguro para o leitor.

Valdir Heitor Barzotto 


\section{Explicações iniciais}


POR QUE A SINGULARIDADE É UMA QUESTÃO?

Esta publicação é sobre a singularidade nas produções universitárias. E a singularidade é uma questão porque permaneceu durante todo o processo de investigação como uma dúvida, uma pergunta, uma procura plena, um problema a resolver, que obrigou nosso olhar a mudar várias vezes de direção.

A primeira tentativa foi a de encontrar a singularidade; depois, a de defini-la; depois, a de desistir de encontrá-la. Finalmente, a de saber que ela não é precisamente localizável e depois que ela não poderia ser localizada, na maior parte das produções lidas, nem de forma imprecisa.

A reconstrução desse percurso é necessária para não perdermos de vista o alvo dos conceitos pelos quais tivemos que percorrer para chegarmos até aqui com a possibilidade de produzir conhecimento sobre escrever uma monografia, uma dissertação ou uma tese.

Tentamos, então, primeiramente, encontrar a singularidade, mas isso foi se tornando cada vez mais difícil. Desco- 
brimos, por exemplo, que a conjunção entre o pesquisador e o autor-citado, mesmo que estilizada, não chegava a ser manifestação de singularidade, ainda que realizada da forma linguística mais original, como equivocadamente chegamos a pensar no início.

Percebemos, também, por exemplo, que uma tese romanceada não necessariamente chega a ser uma manifestação do texto próprio. Inferimos que o estilo é um traço do pôr-de-si do pesquisador nada suficiente para que afirmemos que ali há uma atitude singular, porque, ainda sob o ponto de vista estilístico, a manifestação é formal.

Se a forma não era o espaço suficientemente propício para a manifestação da singularidade, abria-se um intervalo entre o não encontrar a singularidade e a dúvida sobre não saber o que seria propriamente a singularidade. Precisamos de conceito.

Sabíamos que a singularidade que procurávamos nas produções não se confundia com subjetividade, porque não se tratava de encontrar algo próprio do sujeito ou o necessário retorno do trabalho para si; não se tratava também de um exemplar de uma espécie, o uno, nem a metáfora disso: o notável, o extraordinário, o excêntrico, mas alguém que é único pelo que é capaz de suprassumir da humanidade e que, por isso, põe de si para o gênero humano e deixa um rastro que não é simplesmente diferente, mas novo, porque marca um novo caminho, não só através de um jeito de dizer, mas também de uma atitude de trabalhar, fase anterior ao enunciado, as produções.

Indo por um conceito de singularidade que implica o pôr-de-si do pesquisador naquilo que ele faz, inferimos que a singularidade não é localizável. Quando dizemos isso, precisamos lembrar que estávamos procurando a singularidade nas produções universitárias realizadas por um trabalho de escrita que se objetiva pela materialidade linguística. 
Significa, pois, que a singularidade, na perspectiva do pesquisador que a investiga, não é localizável no espaço das palavras, mas dá sinais de forma bastante imprecisa através delas. Porque a singularidade, pensada por este ângulo, não é um fazer linguístico, nem uma tessitura textual, mas uma manifestação discursiva que resulta não exatamente de um dizer, mas de um fazer ontológico, ou seja, próprio do ser, e como a ontologia é a do ser social, a singularidade resulta de um fazer socioideológico.

Ela pode se manifestar nas produções universitárias por indícios de outras determinações que marcam, imprecisa, mas definitivamente, uma escrita.

Se a singularidade é um acontecimento discursivo, isso implica que é também resultado de determinações exteriores, resultantes não simplesmente de escolhas linguísticas, mas de atitudes diante da vida onde o que funda o ser social é o trabalho.

Em função disso, para encontrar a possibilidade de localizar a singularidade nas produções universitárias, primeiro tivemos que compreender que precisaríamos percorrer traços fundadores de uma produção, depreendendo os nexos internos ao conceito de trabalho e sua relação com a produção, correlacionando a escrita a uma atividade laborativa, resultante de uma atitude teleológica secundária, ou seja, intelectual.

Localizamos outros nexos essenciais a uma genuína atividade laborativa, ou seja, percebemos que existem relações internas a uma atividade de trabalho para que ela seja considerada uma fonte de emancipação do trabalhador, quais sejam: o pôr teleológico ou o plano das finalidades; as determinações das necessidades; as alternativas e a liberdade de escolher entre elas como momento primordial da humanidade.

Percebemos que nada disso é suficiente se não houver impulso, pulsão, paixão, curiosidade, para sustentar o movi- 
mento do processo de produção e que tudo isso acontece por determinações também inconscientes.

Descobrimos que a produção entrega ao universal a atividade laborativa do uno que está afetado por um trabalho que põe o novo, garante a continuidade e, a partir dela, promove a reprodução social.

Esse é um processo que condiciona a singularidade ao trabalho e, em igual proporção, às finalidades, às necessidades, às alternativas e às possibilidades de escolher. Em função dessas descobertas, percebemos que, para analisar as produções universitárias segundo o critério da singularidade, teríamos que percorrer essas dimensões que constituem os nexos internos ao trabalho.

Lemos que a singularidade é um juízo de valor, algo a ser avaliado qualitativamente (Japiassu; Marcondes, 1996, p. 268), e não um fato linguístico a ser descrito estilisticamente, porque se manifesta como resultado de uma atitude que dá sinais na escrita. E, nesse sentido, foi tratada, ou seja, na instância ontológica do ser social: o pesquisador/escritor que expressa um pôr-de-si que dá sinais sem que se deixe ser tocado.

Para chegarmos perto dela, teríamos também que nos confrontar com determinações anteriores às produções universitárias: as finalidades, as necessidades, as alternativas, as escolhas do pesquisador.

Disso decorreram os episódios, fruto de momentos não só programados, mas casuais, numa escuta incessante das regularidades que pudemos listar para fazer as inferências sobre a singularidade nas produções universitárias, em torno da qual permanecemos.

Para o exercício da construção da singularidade como juízo de valor, refizemos alguns caminhos de análise, procurando não um jeito de dizer, mas de fazer. E, com esse olhar, identificamos alternativas e decisões dos pesquisadores que 
nos possibilitaram analisar as produções pelas marcas dessas escolhas como indícios da exterioridade.

Não temos aqui uma receita para o pesquisador chegar à singularidade na produção de uma monografia, dissertação ou tese. Não oferecemos aqui um modelo de produção textual.

Mas se a viagem não nos levou ao lugar da singularidade, os desvios do que encontramos no caminho podem ser o grande ganho que oferecemos aos leitores: a possibilidade de viver a liberdade do pôr-de-si através da produção do novo com os utensílios que o ensino superior oferece.

Só não podemos nos esquecer de fazer a parada no poço, para jogar o balde quantas vezes for necessário. Ele estará lá, à beira da estrada, escorrendo água para matar alguma sede. Esta é uma das lições fundamentais que, neste livro, provocam o desejo do desvio.

POR QUE ESCRITA E NÃO TEXTO?

Esta publicação é sobre escrita. Mas não é sobre texto. Porque não estamos nos referindo à produção textual, mas à produção de conhecimento, em virtude de um confronto necessário com o objeto das investigações: a singularidade nas produções universitárias.

Entre saber que estávamos num processo de escrita, que não é necessariamente de um texto, tivemos que percorrer um longo caminho. Isso não estava claro desde o início. Talvez pela área de Letras, o âmbito das palavras tivesse sido a primeira direção. E isso, de certa forma, limitava as possibilidades de pensar em produzir as impressões de uma escrita, porque, no âmbito da visão sistêmica, a análise fica muitas vezes perdida nas descrições formais e, mesmo no âmbito do texto, permanece envolvida numa gramática que restringe a ideia de regularidade à norma e geralmente distorce os traços da exterioridade. 
Os desvios que percorremos também fazem parte do que ao final nos propusemos a fazer: a impressão de uma escrita universitária, a partir da pergunta: tudo se cria, nada se copia?

Reconhecemos que esses desvios, ou seja, os caminhos que não nos ofereceriam elementos para a investigação, foram muito importantes para descobrir aquele que seria. E só chegamos a inferir que não estávamos pesquisando sobre a categoria texto quando organizamos as possibilidades de analisar as produções universitárias, negando o que nos desviaria, com certeza, da análise da singularidade nessas produções.

Pela forma, o lugar mais longe que fosse não nos levaria à construção do objeto, mas sim a uma visão estilística que reduziria produção à categoria texto.

Com isso estamos dizendo que não tomaremos o texto a partir de suas frases, percorrendo-o orientados por uma análise linguística. Não o tomaremos como objeto de análise para investigar nenhum dos níveis da língua: nem o fonológico, nem o morfológico, nem o sintático. Não o faremos também pela noção de continuidade entre eles, na perspectiva transfrástica da Linguística Textual, para recuperar-lhe o sentido através da análise de suas articulações internas (Indursky, 2006, p. 35-73).

Significa que o cotexto não será o motivo de análise, mas o meio: um de nossos utensílios para outras motivações que serão esclarecidas a seguir.

Tivemos que negar, a princípio, toda visão que nos pareceu redutora da passagem que empreendemos para refletir sobre a singularidade, algo que não depende de um jeito de dizer, mas de um fazer diante da vida. Pensamos que nenhuma lógica formal nos garantiria ler a exterioridade que dá sinais na produção textual, mas esta última, dependendo da análise, não garante a manifestação desses indícios que só sinalizam de forma imprecisa. Ir pela análise da forma colocaria o risco de permanecermos nela. 
Mesmo assim, não foi tão seguro iniciar esta escrita, nem a pesquisa sobre a escrita universitária, cenário das produções. Ao mesmo tempo em que nos preparávamos para construir o cenário, analisávamos os produzidos pelos pesquisadores. Era impossível não viver a investigação como laboratório.

Sujeitos às mesmas interferências, tivemos que descolar a escrita do texto, o estilo da singularidade, o falante do locutor, o locutor do enunciador, para encontrar o espaço do pesquisador. Negamos a forma como centro, mas a singularidade também não estava na dimensão do conteúdo. Nossas primeiras alternativas estavam na negação de certezas.

Por exemplo: a exposição que fazemos das negações que tivemos que realizar do nosso processo de pesquisa é elucidativa dessa sensação e dissolve a ilusão de que as produções universitárias veiculam mais certezas do que dúvidas. Quanto mais dúvida, mais incerteza, mais falta - mais negação, mais escolha e mais possibilidades entre alternativas.

Enquanto fomos percorrendo o que não pudemos escolher, vivenciamos lugares que pensamos ser de consolidação dos elementos com os quais acreditamos poder produzir conhecimento sobre as produções universitárias.

Quando vivemos essas incertezas até a desconfiguração do objeto, compreendemos por que, a princípio, no primeiro projeto, chegamos a ter o objetivo de analisar o texto escrito no ensino superior. Mas jamais poderíamos supor que não analisaríamos o texto em si, sua construção, o estilo, nem tampouco o conteúdo, mas teríamos que enveredar por uma escrita que não poderia estar colada à ideia de um fazer linguístico-textual, mas a uma lógica especulativa, à produção de conhecimento como atitude laborativa.

Em suma, a primeira atitude de negação foi da restritiva visão sistêmica. Decidimos proceder a uma análise para além das palavras, sempre com a preocupação de deixar resolvido 
que o lugar delas não seria nossa finalidade, mas uma passagem. Fomo-nos aproximando do centro da investigação: voltamos às produções universitárias para perceber os indícios da exterioridade, ou seja, para analisar as condições de produção pelas quais transita o pesquisador na universidade, ao produzir ou ao reproduzir conhecimento.

Mesmo sabendo que não poderíamos ir em frente sem contar com as palavras, ainda assim permanecemos em nosso processo de negação: indo para além da frase, chegamos à dimensão do enunciado sem considerar a situacionalidade imediata do processo de interlocução entre indivíduos, porque, orientados pelo aqui-agora, estaríamos num espaço aquém da atitude de construir sentido para as regularidades.

Enfim, tendo em vista a singularidade não ser um estilo de escrita universitária, a análise que empreenderíamos durante a pesquisa teria que ser não "do ponto de vista de sua estruturação em língua, mas do ponto de vista de sua realização em discurso" (Guespin, 1976, p. 4), considerando que quem produz é um sujeito social vivendo sob as determinações mais gerais de um contexto que, mesmo parecendo esquecidas, permanecem ali de modo constitutivo.

Permaneciam duas negações que poderiam parecer a negação total de pesquisar sobre a singularidade nas produções universitárias. Negamos a forma e o conteúdo.

Entretanto, descobrindo nesse mesmo percurso que o objeto não está pronto, caberia a nós procurar um caminho que nos possibilitasse construí-lo e, em consequência, produzir conhecimento.

A análise do texto dessas produções não era suficiente, mas a impressão de uma escrita convocaria os elementos que nos possibilitariam lê-las com a referência de uma avaliação qualitativa, para localizar não o estilo do pesquisador, mas a singularidade, resultado de uma postura diante da vida e as 
consequências disso na escrita como atitude e não como produção textual.

Não considerar as produções universitárias como textos e sim como atitude laborativa definiu um caminho possível de análise a partir do conceito de trabalho.

Em confronto com as produções que analisávamos, colocamo-nos na escuta incessante de regularidades; procuramos elementos de análise dessas regularidades na Filosofia, na Metodologia Científica, na História da Ciência; lemos diversos manuais científicos para nos certificarmos do que propriamente está pronto na cultura sobre o modo de produzir na universidade; tivemos acesso a reflexões sobre este contexto sócio-histórico para suportar os desafios da imprecisão com que a Análise do Discurso desarma o pesquisador, ao mesmo tempo em que o põe diante da única saída: a de fazer a impressão do objeto.

Mas começamos lendo sobre os conceitos fundamentais da psicanálise lacaniana, para depois localizar o inconsciente e a ideologia na dimensão do discurso que se constitui de atravessamentos sobre os quais o pesquisador não tem controle. Trilhamos a direção inversa, as direções cruzadas, os desvios e é com isso que vimos até aqui, não para uma produção textual, mas para uma atitude de escrita laborativa, através da qual pretendemos produzir uma impressão das produções.

Definida a perspectiva de produção universitária relacionada a conhecimento e não a texto, esclarecemos que, quando essa categoria aparecer nesta publicação, sempre será no sentido de materialidade discursiva. E, como o discurso é a marca da exterioridade, consideramos também importante esclarecer que ela vai aparecer sob três óticas: a primeira, a realidade em seu sentido usual, como acesso ao que vemos: o mundo que se expõe de forma factual. A segunda ótica é a do reflexo: a sombra do que se expõe, tratado segundo a ontologia lukac- 
siana. A terceira, o real: a dimensão psicanalítica do mundo que está fora da fala, diante da qual as palavras são limitadas. Tratamos desses conceitos porque o pesquisador é colocado diante de um objeto de pesquisa cuja leitura o obrigará a empreender uma luta com o mundo, mesmo que recortado sob um ângulo, o qual circunda seu objeto. Neste momento, a produção não é de um texto, mas de conhecimento. Esse empreendimento de pesquisa que funda as produções é que estamos considerando escrita. 


\section{Conversa franca sobre a escrita na universidade brasileira}


Está mais do que na hora - tanto que muitos já começaram a refletir sobre isso - de confrontarmos a escrita que realizamos na universidade brasileira com a produção de conhecimento. É tempo mesmo de olharmos para os textos que escrevemos na universidade, pensando nos processos que os determinam, ou seja, naquilo que faz as monografias, dissertações e teses serem a repercussão de outras dimensões do pesquisador, não só as linguísticas, usadas muitas vezes para "macaquear" o conhecimento e coroar os autores com citações de frases que nós poderíamos dizer. Entretanto, vamos seguindo como organizadores da dispersão, citando o que não é essencial de uma teoria: frases de efeito.

Mas a filiação que nos obriga a preencher nossa identidade muitas vezes nos cega. Será que precisamos mesmo de um autor para dizermos, por exemplo, que "quando ensinamos a ler já estamos lendo"? Por que categoricamente afirmamos que os autores são essenciais para elaborarmos os documentos provocados por um processo de escrita? 
Quando nos propomos ao confronto, não estamos necessariamente garantindo uma saída, porque se o que ativa o ato de escrever é uma escrita, ou seja, alguma repercussão que atravessa nosso ser, nosso corpo, nossa voz, nossas finalidades, já está posta desde o início a contramão dos manuais de redação. Este livro não é um manual de redação.

Você, leitor, não inicia aqui uma leitura de regras para escrever bem sua monografia, sua dissertação ou sua tese. $\mathrm{O}$ que há aqui é a reflexão sobre a necessária falta, a necessária incerteza, porque vivemos a inevitável manada em cujo centro seguimos todos conduzidos por um cavalo que ginga bovinamente. Acreditamos, entretanto, que cada um vai poder se espelhar no discurso manifesto nos textos analisados, nas atitudes identificadas nos diferentes níveis: graduação, mestrado ou doutorado e, com isso, poderá se desviar de algumas práticas marcantes da reprodução de conhecimento.

Francamente, existem cristais que precisam ser quebrados, para que tenhamos o direito de produzir nossas pesquisas como quem vai à beira do poço e joga o balde quantas vezes for necessário para recolher alguma água. Um tanto derrama, o balde volta; o que vem no balde às vezes não traz nada e volta para recolher o que derramou e traz outra coisa. O que derramou, ou não veio, é produtividade e não vazio. Porque o que esvazia é esse copioso ir e vir, esse repetir das ideias alheias sem a preocupação de avançar do que um autor disse para se perguntar sobre o que fazer com isso que ele disse. Esse processo de pesquisa provoca repercussões nas produções.

É então por essas questões que este livro começa, tentando provocar um deslocamento discursivo, provocando um movimento de ideias e de posições que guardamos como definidas e imutáveis. É bem provável que você se encontre aqui, entre os descaminhos necessários para enfrentar na página o reflexo de um objeto de pesquisa que insiste em não se mostrar e que 
depende muito de suas incertezas para que no meio de suas invenções, aqui e ali, possa dar sinais de si na produção do conhecimento. Por isso é bem melhor que no processo você se perca.

Esse deslocamento de espaço, esse mudar do viés pelo qual se produz tão comumente as monografias, dissertações e teses, exige que se trate de questões consideradas aqui comprometedoras desse avançar da produção de conhecimento. São as seguintes: o diálogo necessário entre Linguagem e Educação e o que deve decorrer dele, sobretudo no âmbito da pesquisa que envolva questões de ensino; o diálogo entre pesquisadores que esboçam o mesmo interesse e os espaços que têm priorizado este debate.

\section{LINGUAGEM E EDUCAÇÃO: QUEBRANDO CRISTAIS}

Vamos fazer menção à possibilidade de despositivizar a frequente cristalização do olhar da Educação para a relação professor/aluno/aula e a frequente cristalização do olhar das Letras para a materialidade linguístico-textual. Essa atitude movimenta as questões limitadas à Linguagem ou à Educação, rompe os cristais positivistas e promove um deslocamento para um lugar de complementaridade entre ambas.

Ora, o Positivismo, fazendo a Psicologia e a Epistemologia encerrarem para si a tarefa da Filosofia, criou uma hipótese de que esta teria que morrer para dar lugar à ciência. A ciência, por sua vez, deveria evitar o contágio com as especulações filosóficas, que foram aproximadas às questões do senso comum e este teria também de ser positivizado, ou seja, domado pela investigação científica (Warde, 1990). Só deveria haver espírito científico. Este reorganizaria a vida intelectual e moral para a nova ordem, sendo condição de progresso para a sociedade que deveria se resignar ao conhecimento positivo 
das leis naturais. O que o Positivismo pretendia era, em suma, o silêncio da Filosofia e a busca do método e da objetividade.

Tratamos deste aspecto porque esse objetivo positivista é uma das sementes da cristalização do conhecimento e de sua representação. Ele alimenta o aspecto das certezas e da neutralidade do pesquisador, na busca da cientificidade.

No confronto com a perspectiva de uma escrita que se processa numa espécie de ressonância, a despositivização das duas áreas se dá pelo viés da Filosofia, da Psicanálise, da Sociologia e da Análise do Discurso que, tocando o linguístico das monografias, dissertações e teses, termina por exigir uma relação estreita das duas áreas, na linha de pesquisa Linguagem e Educação, que interfere nos interesses dos Cursos de Letras e de Educação indistintamente, numa relação complementar indispensável. Os questionamentos são inseparáveis, principalmente quando estão no âmbito da Licenciatura, ou seja, da formação de professor.

A despositivização do texto se deu pelo descolamento da escrita dos limites da materialidade textual. Isso não significa negar essa materialidade ou desprezá-la, mas não permanecer em seus limites. Essa atitude não elimina a leitura. Muito pelo contrário: coloca a leitura como exigência fundamental da pesquisa. Ser pesquisador não se separa de ser leitor e escritor. Atravessar a malha textual para além de uma lógica formal limitada às palavras; rastrear a exterioridade em suas marcas linguísticas é outra exigência. Isso implica, enfim, a análise dos princípios que fazem de um texto um texto, não para analisar se há ou não um texto nas produções universitárias, mas para se inquietar com o que há de produção de conhecimento no texto. Essa atitude exige desprendimento da visão sistêmica, sem poder abrir mão dela.

Por isso, é importante não tomar o texto a partir de suas frases, percorrendo-o orientada por uma análise estritamente 
linguística, mas com o olhar dirigido para outros lugares; não considerar o texto como objeto de análise para criar categorias no fonológico, no morfológico, no sintático; mas rastrear a materialidade linguística em busca de traços indiciários da exterioridade no contexto universitário. Também não analisar os dados na perspectiva transfrástica da Linguística Textual, lendo a relação entre as frases, nem apenas levar em consideração o contexto imediato, mas o histórico (Indursky, 2006, p. 33-79).

Descobrimos que o cotexto, as relações linguísticas, é o meio para ler a interferência da exterioridade em suas marcas; descobrimos também que é preciso negar, a princípio, toda visão que parecer redutora da passagem para o sentido do discurso próprio das produções universitárias, para refletir sobre esse desequilíbrio que desloca da zona de conforto da escrita normal. É preciso negar, para isso, o limite linguístico e descobrir irremediavelmente a dependência dele às outras áreas de conhecimento e vice-versa.

Em suma, negamos a visão sistêmica das produções reduzidas a texto e desvinculadas do conhecimento fechado no linguístico ou no textual. O que poderia provocar um julgamento diante de uma ocorrência linguística passou a ser lido como uma atitude para a efetivação da lógica regida por decisões e acontecimentos vivenciados pelo pesquisador.

Despositivizamos o texto, lendo-o sob a categoria de discurso e as análises foram feitas na dimensão discursiva. Em função dessas escolhas que colocam o discurso no centro das análises e, a partir dele, o sujeito social possibilitou a abstração sobre o ser social. Não era mais ali um pesquisador dentro de uma instituição de ensino superior a escrever uma monografia, uma dissertação, uma tese, mas um indivíduo que, determinado historicamente, é um ser social e interpelado por uma ideologia, um sujeito social. Na verdade, conceitos que foram constituindo a lente para ler as produções universitárias. 
Aqui, o texto é "a materialidade do discurso" (Indursky, 2006, p. 75). E o discurso é o que escapa como marca ideológica do que se pensa estar esquecido. É que "o recalque inconsciente e o assujeitamento ideológico estão materialmente ligados" (Pêcheux, 1997, p. 154). Algumas noções foram determinantes para sair do positivismo linguístico: ser social, discurso, ideologia e inconsciente.

Nesse diálogo, tudo foi se ajustando a uma linha de pesquisa: Linguagem e Educação, fazendo a linguagem tocar a educação e vice-versa; descolando a escrita da materialidade linguística; rompendo os limites das palavras na direção da exterioridade; identificando os limites entre produção de textos e produção de conhecimento; localizando, no dizer universitário, as marcas do perfil da universidade brasileira pela impressão das produções universitárias contornadas sob os conceitos de escrita normal e de escrita laborativa; analisando as consequências dessa realidade para a formação do professor de Língua Portuguesa.

UMA PESQUISA ENTRE OUTRAS NO BRASIL

Existe, no Brasil, uma discussão sobre escrita, singularidade e produção do conhecimento que tem despertado cada vez mais o interesse de pesquisadores que transitam na área de Letras, Educação, Filosofia e Psicanálise. É neste lugar de discussão que localizamos o debate deste livro, sobretudo porque se trata de uma escrita realizada na universidade. Este contexto traz implicações que envolvem a produção de conhecimento e, em função disso, leva a questionar não os textos em si, nos meandros de sua forma, mas a interferência da exterioridade sobre ela, na captura de determinações que envolvem o pesquisador, a teoria, a pesquisa e a construção ou não do objeto, a marca ou não de singularidade. 
É certo que, nessas investigações, diversos são os olhares que procuram a relação entre o que se escreve nos trabalhos de conclusão de curso de graduação, de pós-graduação e o que se produz efetivamente com aquilo que se escreve. Cada olhar prioriza ângulos complementares que constituem a possibilidade de inferir sobre a universidade brasileira, sua realidade e seu sentido.

Nossa intenção aqui é primeiro fazer referências a discussões afins com esta pesquisa e depois apresentar o lugar universitário onde ela se construiu.

\section{DIÁLOGO ENTRE PESQUISADORES SOBRE A ESCRITA NO ENSINO SUPERIOR}

Fazemos menção ao Seminário 12 do cole: "Leitura e Produção na Educação Superior”, que foi coordenado pelo Prof. Dr. Valdir Heitor Barzotto e pela Profa. Dra. Cláudia Rosa Riolfi. Este seminário vinha constituindo um espaço para discutir leitura e escrita na Educação Superior e reunindo pesquisadores que não pertenciam a um mesmo grupo de pesquisa, mas se afinavam pelo contexto que sustenta suas reflexões: a universidade. Selecionamos alguns para localizar as reflexões deste livro entre as discussões sobre escrita, singularidade e produção do conhecimento, as quais estão acontecendo no Brasil. Abaixo, apresentamos trechos das discussões que os referidos pesquisadores provocaram naquele Seminário 12, em 2009:

Severino (s/d):

O olhar atento sobre essa produção mostra o uso desgastado das palavras, como que acobertando um silêncio de potencialidade criativa das novas gerações, como se estivesse ocorrendo uma interdição da escrita e sua 
substituição pelo plágio, pela paráfrase incontida, pelo abuso das citações, enfim, pela abdicação da autoria autêntica. Neste Seminário, a questão é colocada no âmbito da produção escrita no ensino superior, tratandose, pois, de discutir o que vem acontecendo com essa produção, marcada que também está por essa corrosão degenerante. A conclusão a que se tem chegado é a de que nunca se pensou tão pouco... e se escreveu tão mal...

Cintra (s/d):

A impressão que temos é que o leitor acadêmico inexperiente trabalha sobre o texto escrito como se estivesse numa posição de escuta em relação ao autor e, como mero 'ouvinte', não se permite associações, analogias, comparações, a partir de seus conhecimentos, de sua intuição. Também não se permite ler nas entrelinhas, pois não foi preparado para ser capaz de fazer inferências, de assumir sua própria voz, de discutir, de questionar.

Grigoletto (s/d):

[...] onde fica o sujeito aluno e de que posição ou lugar ele pode falar ou escrever. Ainda que se espere dos alunos e das alunas que se apoiem fortemente nos textos teóricos estudados para as suas reflexões e análises, é preciso começar ao menos garantindo um distanciamento mínimo por meio do qual o aluno se coloque numa posição enunciativa própria, isto é, numa posição enunciativa de comentador ou resenhista, que seja. Como entrar no processo de escrita garantindo esse mínimo pelo menos? 
Lopes (s/d):

Os textos produzidos pelos alunos na universidade têm sido comumente avaliados pelos aspectos da superfície textual, como a referenciação, a pontuação e a ortografia ou, ainda, pelo atendimento às características do 'gênero acadêmico', numa tentativa de homogeneização dos aspectos formais e discursivos dessa produção. [...] Questionando essa tentativa de 'universalização', propomo-nos refletir, neste trabalho, sobre a possibilidade de emergência da singularidade na produção escrita de alunos do ensino superior [...]

Outras pesquisas, apresentadas naquele Seminário em 2009, como as de Barbosa (s/d), Soares (s/d) e Ghiraldelo (s/d) sobre a escrita no ensino superior estão ligadas a este debate, porque tocam a consequência desses questionamentos na formação do professor, extremamente descaracterizada na disciplina Prática de Ensino de Língua Portuguesa, ponto que poderá ser discutido pela análise das monografias de conclusão de curso que, tratando sobre ensino, desviam-se com regularidade de seu objeto.

Fazemos também referência à pesquisa de cooperação acadêmica que investiga sobre a disciplina Metodologia do Ensino de Língua Portuguesa (MELP), tal como ela tem se configurado nos Cursos de Formação de Professor de Português no Brasil ${ }^{1}$. A implementação dessa pesquisa justifica-se ainda

1 Refiro-me ao Projeto de Cooperação Acadêmica: Disciplinas da Licenciatura voltadas para o Ensino de Língua Portuguesa apoiado pela CAPES através do PROCAD-NF (Projeto de Cooperação Acadêmica entre a Universidade Federal do Maranhão, a Faculdade de Educação da usP e a Universidade Estadual do Rio Grande do Norte. Esse projeto inicialmente teve o apoio da FAPEMA 
mais por constituir um contexto de cooperação para consolidar programas de pós-graduação.

A investigação sobre a disciplina MELP analisa dois contextos de extremo interesse para a educação brasileira: a formação de professores de língua portuguesa e a produção de conhecimento neste domínio. Este livro, na medida em que analisa a escrita nos cursos de licenciatura, está também incluído neste Programa de Cooperação Acadêmica, aprovado em dezembro de 2008 pela CAPES, uma vez que oferece análise do discurso do professor de Língua Portuguesa em formação.

ESPAÇOS QUE TÊM PRIORIZADO O DEBATE SOBRE ESCRITA NO ENSINO SUPERIOR

Uma pesquisa sobre escrita parecia a princípio a exigência de uma análise linguístico-textual com indícios visíveis ao pesquisador diante da superfície do texto. Olhar para o texto, estudar sobre texto, avaliar os critérios de concatenação entre as partes de algo produzido na universidade seriam algumas tarefas que nos caberiam.

À medida que o linguístico-textual foi sendo colocado no seu espaço, mais a escrita foi se manifestando como atitude do pesquisador, como trabalho, como tentativa em vão de tocar o real e como tentativas de produzir conhecimento. Isso sem esquecer que as monografias, dissertações e teses se materializam em textos, são feitas de palavras.

Acreditamos que só por esse descolamento da escrita seria possível movimentar a noção redutora de texto e realizar a descoberta de que há na universidade uma restrição da escrita à categoria texto. Quando escrever um texto, seja ele uma mo-

(Fundação de Amparo à Pesquisa e ao Desenvolvimento Científico e Tecnológico do Maranhão), que também apoiou as investigações deste livro. 
nografia, uma dissertação, uma tese, é mais importante do que tomar, na atitude de escrita, o desafio de construir um objeto, todos os esforços são simplificados na malha de uma escrita normal. Só começamos a pensar sobre isso no Grupo de Estudos e Pesquisa Produção Escrita e Psicanálise (GEPPEP), que discute e investiga a escrita.

O GEPPEP ${ }^{2}$ passou a ser o lugar de reconhecimento da necessidade da falta para produzir conhecimento. $\mathrm{O}$ conhecimento foi se configurando uma alentadora invenção, e escrever sobretudo no âmbito das Ciências Humanas é processo dessa invenção, diante de um intocável objeto de investigação.

Mas inventar ninguém ensina. O que chamamos de ensino é uma provocação do desejo de inventar que se manifesta a despeito do preço que quem escreve tem que pagar. Só se aprende pelo desejo e não pelo prazer. Aprender custa o preço de um trabalho de nunca saber, mas a paixão faz encontrar uma saída para chegar o mais perto possível do intocável: o conhecimento, movimento para outro lugar.

Fazemos a seguir duas citações dos pesquisadores que conceberam o GEPPEP, Prof. Dr. Valdir Heitor Barzotto e Profa. Dra. Claudia Rosa Riolfi, para que fiquem exemplificadas questões fundamentais das concepções de pesquisa do grupo:

A criança, neste caso o oprimido da escola, em certa medida coincide com o autor do texto, que a apresenta como tal. Ao mesmo tempo em que este dá a ver uma criança, cuja imagem é a de um sujeito que precisa ser adornado pelo pesquisador para ser percebido como tendo valor, o próprio pesquisador, ao adornar-se com textos de outros autores e, às vezes, com textos das próprias crianças, parece encenar a criança, mostrando-se

2 http://paje.fe.usp.br/ geppep/index.htm. 
como alguém que também precisa de voz e de um lugar para ela. Os textos nos quais o pesquisador se apoia constituem uma voz dada a si mesmo, apanhada de outros pelo pesquisador como quem diz eu não sei, mas meu pai sabe ou eu faço igual a meu pai, num exercício de autovalorização (Barzotto, 2006).

E também:

Pesquisa-dor é aquele sujeito que, mais longe o possível das amarras que lhe impõem os diversos ideais, mergulha - implicado em todo seu corpo - na tarefa única e, de resto, para cada um absolutamente singular, de pesquisar a dor específica de sua existência (Riolfi, 2009).

Neste debate, esses dois pesquisadores estão diante de um grupo que analisa versões de textos escolares e científicos, objetivando mostrar que a imobilidade da escrita consiste em uma falácia, pelo seguinte:

a) do ponto de vista de quem escreve, vários movimentos com relação a sua própria palavra são necessários para poder produzir um texto passível de interpretação pelo leitor;

b) do ponto de vista de quem lê, um texto pode gerar movimentos, alterações, transmudações;

c) do ponto de vista do processo por meio do qual se escreve, a análise das diversas versões de um texto mostra que as palavras movimentam-se com maior ou menor propriedade até que venham a se depositar na fixidez de uma versão considerada final (Pesquisadores..., 2009).

Além disso, há investigação a respeito dos modos por meio dos quais as palavras de terceiros são incorporadas por quem escreve; há alterações perceptíveis na posição escrita de quem escreve durante o seu percurso investigativo; nos mo- 
dos por meio dos quais um sujeito paulatinamente se apropria da leitura e da escrita. Há investigação a respeito das transformações existentes entre as diversas versões de um mesmo texto e a respeito das influências exercidas pelo parceiro (professor, orientador, amigo etc.) no percurso de quem se propõe a escrever (Pesquisadores..., 2009).

As reflexões deste livro integram, então, o GEPPEP, Grupo de Pesquisa da Feusp, onde se desenvolve o Projeto Movimentos do Escrito, no eixo temático "O que foi lido no texto escrito: investigação a respeito dos modos por meio dos quais as palavras de terceiros são incorporadas por quem escreve". Elas estão ligadas à formação do professor de Língua Portuguesa pela análise das monografias, dissertações e teses elaboradas no Curso de Letras e de Educação de diversas instituições de ensino superior no Brasil, fato que as inclui entre as discussões do PROCAD-NF (Programa de Cooperação Acadêmica entre a Universidade Federal do Maranhão, a Faculdade de Educação da usp e a Universidade do Estado do Rio Grande do Norte) através do Projeto de Cooperação Acadêmica: Disciplinas de Licenciatura voltadas para o ensino de Língua Portuguesa, coordenado na IES Associada I pelo Prof. Dr. Valdir Heitor Barzotto, que orientou esta pesquisa e que milita pelas questões do escrito, da produção de conhecimento e da formação de professor no Brasil.

Entretanto, ainda nos cabe esclarecer aos leitores que as reflexões sobre a escrita no ensino superior tocam de perto os pesquisadores das outras áreas, porque as condições de produção são próprias da universidade pela qual todos transitamos. Aqui, muitos leitores, mesmo aqueles que não atuam na área de Linguagem e Educação, poderão se mirar nas águas de um poço ou na manada comprimida em bicho inteiro, centopeia. 


\section{Conceitos fundamentais para pensar a escrita}


Quando descolamos escrita de texto, em nenhum momento pensamos que texto é menos importante que escrita, mas que a escrita não se limita a texto, pensado como um resultado lógico, como produto do pensamento, nem como codificação de um escritor para a decodificação de um leitor, para a qual se supõe, equivocadamente, suficiente o código.

Situamos texto para além do limite do linguístico, sem que esteja fechado na malha textual onde elementos linguísticos mantêm entre si "relações de interdependência [...] em ordem coerente e consistente [pela qual] cada segmento textual contribui para a inteligibilidade daquele que segue [...]" (Weinrich, 1973, p. 174).

O descolamento entre texto e escrita, mesmo nos apropriando da ideia de que a completude textual é uma ilusão, facilitou a possibilidade de abstrairmos sobre produção de conhecimento, sobre a relação entre trabalho e escrita, esta que também não se limita ao ato de escrever propriamente dito. $\mathrm{E}$ isso foi feito na medida em que tomamos o texto não como su- 
perfície linguística fechada em si mesma, com começo, meio e fim, mas como processo discursivo, incompleto, procurando ver como ele manifesta sua relação com o histórico-social e vai o mais perto possível desse processo, construído numa espécie de dispersão de sujeitos. A escrita é então o desafio dessa dispersão que o pesquisador acredita poder organizar.

Quando dizemos que é escrita e não é texto, percebemos o quanto é curioso enfrentar a escrita como trabalho de invenção científica e o quanto é surpreendente tentar tocar essa dispersão. Os conceitos que favoreceram abstrair sobre isso foram, a princípio, o de trabalho, sob a ótica da Ontologia do Ser Social de Lukács e os de reflexo, real, falta, escrito, impressão, discurso, singularidade, sobretudo porque esses conceitos rondam o ponto em que a escrita, para produzir conhecimento, tem que se desprender das certezas e das garantias. A escrita é o processo pelo qual o pesquisador fareja o objeto.

É muito importante saber que a escrita de que aqui tratamos tem base nos seguintes conceitos:

- REFlexo é o que se manifesta ao pesquisador no primeiro momento diante do objeto. "Nasce uma nova forma de objetividade, mas não uma realidade e - em sentido ontológico estrito - não é possível que a reprodução seja da mesma natureza daquilo que ela reproduz, tanto menos idêntica a ela.» (Lukács, ${ }^{3}$ 1981, p. 38).

- REAL é o impossível, "situado fora de todo campo demarcável” (Kaufmann, 1996, p. 445). A ele é conferido o estatuto do vazio. O real é o que escapole, o que "arrasta consigo o sujeito e quase o força” (Lacan, 1998b, p. 55-56). Na perspectiva teórica

3 Utilizamos neste estudo a tradução de Ivo Tonet da obra LUKÁCS, György. Per l'ontologia dell'essere sociale. Roma: Riuniti, 1981. Em vários momentos a cotejamos com a edição italiana, cuja paginação foi considerada nas referências. 
do discurso, a concepção de língua afetada pelo real permite reconhecer o equívoco constitutivo da estrutura (Pêcheux, $1990 b$, p. 55).

- FAlta é "o vazio traumático em torno do qual se articula o processo significante" (Zizek, 1991, p. 14).

- TRABAlHo é a protoforma do ser social, tal como concebeu Lukács (1981) em sua Ontologia.

— Escrito é "o que está do lado do objeto" e, portanto, “o estatuto é real e não simbólico" (Zizek, 1991, p. 67-68). O escrito nunca se escreve. Diante disso, a escrita é o ato de um sujeito que, diante de um objeto, não sabe que, "ao avançar para trás da cortina, ele mesmo levou para lá o que ali encontrou” (Zizek, 1991, p. 32).

- овjEto, aquilo que "se evapora entre os dedos (...), só pode persistir na sombra, (...) é não realizado, (...) um lugar vazio rodeado pela estrutura" (Zizek, 1991, p. 32).

- DIsCuRso é o objeto socioideológico que se depreende da materialidade linguístico-textual através da regularidade que se manifesta entre as produções e que não se limita ao produto: o texto. Essa regularidade é o que dá indício à dispersão de textos. Entender o discurso exige a concepção de linguagem com a interferência do sócio-histórico (Pêcheux, 1997).

- SINGUlaRIDADE, as marcas do pôr-de-si do pesquisador no que faz, "o colocar algo de si" (Lacan, 1998a, p.11) em seus processos de escrita.

- IMPRESSÃo é o vestígio resultante de pressão sobre um objeto, alguma marca, sinal, efeito produzido, sensação diante do que foi possível separar como atitude do pesquisador.

Esses conceitos talvez expliquem a metáfora do poço que leremos mais adiante e nos façam entender que, quanto mais desafiamos ser pesquisadores, mais arriscamos ser inventores e aventureiros, sobretudo quando estamos no âmbito das ciências humanas. 
É em função desse modo de ler a escrita que iniciamos este livro, negando-o como manual de redação. Acreditamos que as monografias, dissertações e teses só produzem conhecimento pela perda das saídas. Não oferecemos um caminho de regras e estratégias. Pelo contrário: acreditamos que escrever, passando pelo processo do que estamos chamando escrita, seja fechar as estradas pelas quais transitamos todos os dias a ponto de não mais pensarmos nelas. Pensamos a escrita como trabalho, tal como é construído na Ontologia do Ser Social em Lukács.

E o trabalho é semelhante ao fato de enfrentar a impossibilidade de sair. Quando isso acontece, é exatamente o primeiro passo para buscarmos saídas. E isso não ocorre, se temos certeza de que elas existem. Ninguém procura pela porta de saída da própria casa. Mas, se, numa situação de emergência, ela fica bloqueada, imediatamente o desespero desencadeia a procura. No âmbito da investigação, o pesquisador passa a buscar uma saída diferente quando a porta tão conhecida - a repetição dos autores - foi invalidada como tal (informação verbal) ${ }^{4}$.

Palavras e expressões como farejar, rondar uma falta, circundar a incerteza, persistir com o balde diante de um poço são próprias de um processo de investigação cujo objeto não está diante do pesquisador fazendo pose para ser copiado. $\mathrm{O}$ que faz com que o processo de pesquisa assuste muitas vezes o pesquisador é que o objeto, a princípio, não existe.

O escrito, aquilo que não se escreve, está do lado do objeto; quem leva para detrás da cortina o que pensa já estar lá é o próprio pesquisador. A linguagem é uma estrutura que rodeia o objeto, mas não o contém. Tudo isso está implicado no conceito de reflexo. $\mathrm{O}$ objeto de pesquisa, filosoficamente falando,

4 Palavras do professor Dr. Valdir Barzotto em sessão de orientação (2009). 
é uma sombra, uma hipótese de existir. Se o leitor olhar para trás e rememorar o início de um processo de pesquisa que tenha vivenciado, talvez veja que o objeto que, a princípio, seria uma girafa virou um pavão. Mas, se, ao contrário, a girafa permaneceu girafa do início ao fim, talvez comece a pensar no conhecimento que reproduziu.

Resulta do que acabamos de afirmar quatro consequências dos conceitos que geram esta visão de escrita de que aqui tratamos: reconhecer a incompletude, a própria falha e, por isso mesmo, se colocar a trabalhar; tensionar com o já sabido como estratégia formativa, incluindo aqui a formação do professor; reconhecer que a singularidade implica o pôr-de-si do pesquisador naquilo que ele faz; perceber que a singularidade não é localizável, apenas dá sinais de forma bastante imprecisa.

Essas consequências não estão ligadas a um fazer estritamente linguístico, nem é uma questão restrita à análise de uma tessitura textual, mas é manifestação discursiva que resulta não exatamente de um dizer, mas de um fazer ontológico e socioideológico. É manifestação não do ato de escrever em si, o fazer textual, mas da atitude de escrita.

Essas ideias nos fazem perceber que o pesquisador não chegará ao conhecimento pleno do objeto, mas a uma impressão, a um vestígio resultante da pressão sobre o objeto, alguma marca, sinal, efeito produzido, sensação diante do que foi possível separar como atitude do pesquisador, este que é indivíduo, ser social, sujeito social, sujeito de desejo que entrega seu corpo para que a paixão lhe possibilite inventar. 


\section{Lições fundamentais para pensar a escrita}




\section{LIÇÕES DO POÇO}

O conciliar a ida ao outro, o estar diante das regras de cultura e o lugar próprio, ou seja, o espaço único, diferente desse outro, mas idêntico a ele, é o paradoxo do espelho, diante do qual esse mesmo lugar nos mostra que temos de ser diferentes do modo como nos vemos e jamais conseguiremos ser iguais ao que pensamos ser. É quase assim o dilema da escrita.

A escrita, esta que nos diz respeito mais de perto e que aqui tomamos como objeto de análise, coloca-nos diante desse impasse. Talvez alguma atitude nos tire da condição de sujeito do conhecimento e nos lance de cabeça às profundezas como sujeitos do significante e possa nos restituir o amor pela produção escrita, mesmo sabendo que chegar ao real, através dela, seja uma ilusão necessária, alguma tentativa a mais que nos faz sentir termos chegado a esse lugar do inalcançável, que, fora da fala, escondese de nós. Ilusão que nos possibilita denominar a escrita de momento infernal pela impotência do dizer até onde seria preciso. 
Para esse inferno, há vários lugares: o primeiro lugar onde podemos colocar a escrita como inferno talvez seja este: ficarmos fingindo que tocamos o real, quando ele é impossível de ser circunscrito, enquanto novamente ele se escondeu. Porque o pior dessa atitude - esta que ainda nos orienta - e que, por cegueira, não conseguimos ver, é uma outra forma de inferno: esforçamo-nos o máximo possível para escrever do jeito que todo mundo escreve na academia; procuramos o modelo onde a grande conquista do pesquisador seja a neutralidade; apagamo-nos completamente no outro da ciência e temos a pretensão de tê-lo conseguido no poder do título, como ideal. O segundo lugar do inferno: vamos pelo lado de nós mesmos, na ilusão de subverter o modelo; desafiamos a academia, colocamos o que há de nós, deste cada qual, nossa subjetividade. E não nos damos conta de que o grande esforço seria nossa des-subjetivação. Ou seja, colocar uma força genérica, própria do gênero humano na pesquisa que realizamos. Isso implica abrir mão daquilo que nos diz respeito; em particular, entregar o corpo para a universalidade expor sua ignorância na travessia dos tempos e perguntar aquilo que não conseguiremos responder, mas que alimenta a sede, feito um balde que fica na beira do poço se escorrendo por um fio de água para matar a sede de uma criança que vai crescer.

- antes do inferno da escrita: o inferno da pesquisa. Esta pesquisa que chamamos de inferno tem, neste caso particular, um caráter infernal pelo próprio objeto: a escrita. E a produção na universidade é este cenário de conflito onde o pesquisador, inevitavelmente, terá que viver um enfrentamento com a página onde ele deseja capturar o real, numa situação de eterna falta, na garantia de uma tradução da realidade, esta que é a parte que se mostra, mas não satisfaz.

Quando tratamos o real, referimo-nos a algo que é apenas reflexo, sombra do que é possível observar. Nessa sombra, 
o objeto é um contorno possível e, numa folha de papel, o sentido escorre feito fios de água que vão desmanchando os já ditos e favorecendo a perda do pesquisador. As dúvidas vão sendo tecidas na medida da necessidade das certezas que ele teria que escrever como garantia de resultados.

Quando é lido o conceito de real em Lacan e o de reflexo em Lukács, essa angústia de escrever encontra uma certa justificativa. Para Lacan (1998b, p. 55-56), este "real escapole e arrasta consigo o sujeito e quase o força” e, para Lukács (1981, p. 38), “o ato de reflexão do real pela consciência dá origem a uma 'nova objetividade' que confere um caráter dual ao mundo dos homens". Esta realidade, a parte que se mostra, "é uma nova forma de objetividade, mas não é uma realidade" (Lukács, 1981, p. 38). Pensamos que, se quem escreve só perscruta o real, ele apenas se debaterá no significante e entrará no delírio poético. Mas, se o pesquisador não se satisfaz apenas em descrever a realidade, ele entrará no inferno da escrita e produzirá, pela curiosidade apaixonante, algo de criação, sem abrir mão do legado.

No início desse processo, lemos produções universitárias para analisar indícios de como os pesquisadores lidavam com os autores. Encontramos no outro pesquisador o que incomoda: essa necessidade de ancoragem em algum autor para, na maioria das vezes, repetir a lição, não para aprender com ela a ir para um outro lugar. Gostaria de deixar claro que, em nenhum momento das reflexões, acreditamos na necessidade de dispensar os autores; cremos, entretanto, que, repetindo fragmentos tirados de suas ideias, fragmentos que não chegam a revelar um conceito, estamos negando as lições dos mestres. Percebemos, inclusive em outras leituras, que o autor chega a ser, em muitas pesquisas, o ponto de partida.

Naquelas produções universitárias, procuramos alguma marca de singularidade: aquilo que no único ganha força na 
direção do gênero humano. Mesmo na tentativa infernal de dizer sobre este pôr-de-si do pesquisador atravessado pelo particular para chegar ao universal, pensamos em encontrar naquelas produções o universal no singular, decorrente de um sentido construído por um pesquisador implicado em sua busca. Entretanto, num primeiro recorte, o que encontramos foi generalização em enunciados que se anulavam internamente e que davam indícios de que o sujeito não é tão simples assim na medida em que um único enunciador é representativo, consciente ou inconscientemente, do particular, o grupo ou os grupos a que pertence.

Eis uma lição de Ducrot (1987). Ele ensina que há uma pluralidade latente no singular e um aparente controle do enunciador sobre um enunciado que deixa marcas de uma enunciação determinada por uma escolha ideológica que não foi feita. Mas, na escrita, se o simples é coletivo, podemos usar isso como desculpa para repetir. E, se nos negamos a repetir, também não podemos abrir mão das regras de cultura. Localizamos o inferno na tentativa do equilíbrio entre o legado e o que fazemos com ele na luta infernal de uma escrita singular.

Durante a análise dessas produções, fizemos um levantamento de marcas das tendências mais presentes na produção escrita do Ensino Superior e depois selecionamos as que consideramos indícios materiais que não caracterizassem uma preocupação puramente normativa, porque nos preocupava o conhecimento produzido através desses textos e a produção escrita cujo conteúdo também seria duplicador de nossas perguntas.

Lendo o texto escrito e perguntando sobre a escrita na universidade, levantamos alguns eixos importantes para observar durante a leitura: primeiro, aspectos formais, que depois foram sendo colocados em segundo plano até deixarem de ser relevantes para o que depois passou a nos interessar: o 
inferno da pesquisa que gera o da escrita. Começamos a perceber que, entre as tendências indiciadas naquelas produções acadêmicas, havia um deslocamento do autor para o centro da pesquisa e o apagamento do pesquisador. A maioria dessas produções se sustentava em clichês teóricos e colocava os autores como justificativa da pesquisa. São os autores o respaldo das críticas e das inferências. Eles são chamados a comparecerem na escrita para confirmarem o óbvio, para lembrarem algo ao pesquisador, para ajudar a definir o objeto, para criticar uma prática. Não foram raras as vezes que, nos textos selecionados, o pesquisador declarou compartilhar a ideia de um determinado autor ou estar sustentado por ele.

Por exemplo: um autor não precisa ser convocado para dizer que "quando se ensina a ler já se está lendo". Frequentemente o autor foi considerado âncora, sustento, base e apoio. Sem nenhuma intenção de negar o autor, o mestre necessário para a produção escrita na universidade, no que chamamos de apagamento do pesquisador, ficou difícil, na maioria das produções, localizar o lugar do pesquisador, sufocado que se revelou numa escrita onde ele declara precisar de uma ancoragem.

E essa necessidade se coloca de tal forma que parece que ela é suficiente. Inferimos que o que poderia gerar categoria, conceito, a partir do qual o pesquisador pudesse refletir sobre o objeto e alimentar sua falta, passou a ser citação de conceitos ou reprodução de definições, gerando uma tendência que consideramos muito mais teórico-descritiva para uma escrita cômoda, onde o modelo prevalece.

- a presença do orientador. Ensaio aqui articular algumas possibilidades a que a escrita pode nos levar e esboço a possibilidade de chegar a um ponto, onde o que não faz sentido é o que pode levar ao reflexo do real. Contorno mais uma vez 
o real pela literatura. Encontro Dante, que se encontrou com Virgílio pelo inferno da Divina Comédia. Da escrita acadêmica, vou descendo às profundezas pela metáfora do poço e por alguma melodia que está para além do ruído deste teclado, talvez do piano que toco de ouvido cuja música hoje escuto muito mais nas palavras. Ponto importante para isso: o processo de produção, enfocando a interferência do meu orientador como parceiro nesta experiência. Começo outra escrita. Ela não é mais tranquila que as anteriores. Sempre inédita e, numa certa medida, em vão.

Para essa interferência, preciso contar um episódio: ao iniciar a fase de escrita do texto, resultado das leituras das produções universitárias citadas no item anterior, havia a necessidade de dizer sobre aquilo que ali se insinuava para além de mera preocupação. Eu era ali uma pesquisadora afetada por questões que me diziam respeito. Uma implicação instalava outra necessidade: a de dizer mais livremente sobre algo que não era apenas uma questão intelectual, cognitiva, científica, acadêmica. Era ali uma pesquisadora cujo corpo é caixa de ressonância de uma energia psíquica. Eu precisava materializar, mesmo que parcialmente, aquilo que me surpreendia, me envolvia e que estaria, em grande medida, fora da possibilidade de ser simbolizado. Hoje, depois de várias leituras, já é possível dizer que se tratava ali do real, a sombra da realidade.

Sabia que, só pela neutralidade exigida na produção universitária, seria impossível chegar perto de dizer sobre o dilema de todos da academia: a escrita. Se a academia é um dos meus espelhos, o dilema também é meu. Uma lida própria ao pesquisador. Lida específica do lugar de pesquisador que exige a leitura daquilo que, ao se esconder, meio que se mostra. Uma lida. Nela, já se instala o inferno da escrita.

Mas chegou a hora de escrever o texto e enviá-lo a meu orientador. Na primeira versão (primeira que enviei a ele), sa- 
bia que o dilema a que acabei de me referir estava ali. Só depois que ele fez a leitura, pude localizar a quebra que havia entre o que era próprio a qualquer pesquisador, digamos, a linguagem científica, e o que poderia ser alguma marca de singularidade na voz de uma pesquisadora implicada numa escrita e, naquele momento, em (sua) escrita acadêmica. Assim foi a quebra: no primeiro momento, imparcialidade; no segundo, parcialidade; no terceiro, imparcialidade.

O meu orientador, em nenhum momento, questionou a metáfora naquele contexto. Pelo contrário, fez as observações necessárias à análise que ali apresentava do corpus e, num trecho do seu e-mail, disse o seguinte:

Deixar toda a parte que traz a psicanálise para apresentar no workshop do GEPPEP. Dei uma entrada na sua parte mais poética, você pode não aceitar. Mas uma sugestão que já dei é manter o poético até o fim. Você abandona. Acho que a metáfora da água se perdendo precisa ser mantida ao longo do texto, ou recuperada mais no final.

Sobre a metáfora, só fui até a metade dela. A imagem era de um poço. Diante dela, fui até a subida do balde, como se puxar água dependesse simplesmente de uma jogada. $\mathrm{O}$ meu orientador abriu uma parceria. Foi assim. Eu disse: "Escrever é ter, pouco a pouco, acesso a esse lugar, meio como se fôssemos puxando água de um poço, num balde que às vezes sobe vazio". E ele, entre parênteses, escreveu o seguinte:

[...] prefiro assim: (um balde) que pode vir se esvaziando enquanto sobe e que ao chegar à boca do poço não encontra outra possibilidade a não ser, para cumprir seus desígnios, ver-se atirado no vazio novamente a fim de recolher, de uma só vez, o que perdera aos poucos 
pelo caminho. E trazer o vazio ou precipitar-se nele é também revelação: do desaguar do sujeito ao precipício da ausência de sujeito. E se a água perdida pelo caminho não pode mais ser recuperada, ao vir à tona, ela mostra que, camuflados por traços da multidão que nos faz, somos idênticos ao que não conseguimos ser.

Na minha metáfora não estava clara a persistência que faz da escrita o necessário inferno de ir ao fundo do poço e voltar várias vezes para recolher o que sempre derrama. Quando o assunto voltou à tona, ou melhor, quando chegou o momento de voltar àquelas águas que ficaram fora do balde, ou seja, quando precisei voltar a pensar na psicanálise que tinha deixado para recuperar no texto do workshop, quase me recusei. Cheguei a pensar que não estava me sentindo à vontade para recolher aquelas águas que tinham derramado.

Compreendo, inclusive, que a minha meia-metáfora era consequência de um conhecimento parcial: primeiro, das lições do poço; depois, das noções de sujeito, sem ter até ali me dado conta de que, para chegar à plenitude daquela metáfora, seria preciso a experiência do poço como dado do outro para o espelho e um conceito para lê-la. O meu orientador tinha as duas. Sobre o poço, ele me disse numa sessão de orientação:

$\mathrm{Na}$ casa de meus pais havia um poço. A família crescia, a casa ia aumentando, mas o poço não: sempre ficava ali, no mesmo lugar. $\mathrm{O}$ balde às vezes rachava. Meu pai puxava água e o balde vinha escorrendo. Ficava só um pouco de água pra matar nossa sede. Enquanto ainda restava um pouco, ele ficava tranquilo.

A metáfora passava a ser ali um ponto de cumplicidade. 
Havia na música daquelas palavras a voz da criança que só morre se for de saudade.

Desse episódio, pude inferir que o poço lhe possibilitava ali organizar a imagem da casa da infância. Uma metáfora que ele desconstruía através do conceito de sujeito do inconsciente. E mais: a água derramando ou escorrendo aos poucos, depois de puxado o balde rachado e retorcido de tantas idas, insinuava o em vão: movimento para matar alguma sede.

- diante do poço, um parêntese para o delírio. Esta não é a primeira versão final que escrevo. Sinto-me diante das infinitas possibilidades do não-dizer. Exponho-me no meu inferno da escrita sobre a escrita. Volto para o momento em que tentava traduzir o inferno de quem quer escrever e reconheço a tentação de transferir a responsabilidade para que o outro diga o que não consigo. Procuro o equilíbrio entre o real e a realidade; o meu lugar e o dos autores; o literário e o científico; a minha força e a força genérica, humana, que há em mim. Descubro que o inferno é uma condição de todos nós. Volto então para as águas que caíram fora do balde sem a certeza de que será possível saber se há ainda aqui pelo menos parte daquelas primeiras, quando me foi sugerido não falar delas. $\mathrm{Na}$ verdade, estou quase certa de que o que escrevo é resultado do efeito de outras quedas. Aquele tentar trazer e derramar é quase evanescente.

Mas de nada iria adiantar voltar atrás, porque a minha ida ao poço agora é outra. Entre linhas de águas, mas nas linhas de palavras. Dentro desses caminhos escuros, a música é da água e o teclado, do piano por cujas notas me aventuro enquanto escrevo. É a sombra do reflexo que me ilude. A sombra do real diante de uma realidade que não me satisfaz. Palavras que matizam de azul este inferno e me garantem nestas linhas, enquanto vivo a ilusão desse eu que o espelho reflete e me ensina de 
mim a partir do outro. E tudo isso misturado não pode apagar este fogo da escrita, metáfora de meu corpo, espaço para onde eu me desloco para que o sujeito que há em mim se reconheça.

No inferno da escrita, descubro que, na condição de pesquisadora, componho a minha divina comédia. Como qualquer um, na travessia para o outro lado da esfera para onde vou pesquisar, o non sense me corta. Eu digo e o que é sujeito em mim faz outra coisa. Eu faço outra coisa, mas o que é sujeito em mim diz o que não ouço. $\mathrm{O}$ que há do sujeito nesse eu que assina e me garante? O que há dele que vai escrevendo tão escondido, ao ponto de eu deixá-lo cair de mim no poço? É a música das palavras caindo nas águas. Escrevo. Leio o que escrevi e chego a não ver o que o sujeito que me constitui escreveu, deixando escapar o que eu queria conter.

Mas o que é sujeito em mim subverte, compõe na ilusão do reflexo. E diz sem que o autorize, porque o que eu autorizo talvez ele não tenha dito. Ao mesmo tempo, o eu iludido assina e muitas vezes repete. Neste lugar, repito: é regra de cultura a ilusão da conquista de escrita capaz de revelar, com exatidão, o real; a ilusão da imobilidade das produções; o senso comum que ela instaura; a repetição que a filiação provoca na academia.

$\mathrm{Na}$ condição de pesquisadora, sempre tenho que descartar palavras para dizer o que está fora da fala. Umas vão derramando enquanto o balde sobe e outras, derramo de propósito pelas lições do espelho. Essas - tanto as que jogo, quanto as que perco - poderão depois aparecer evanescentes em algum verso, através do qual eu possa exercer minha divina comédia no inferno da escrita, tanto quanto Dante, ou diferente: na musicalidade das águas cujo som eu escuto através deste teclado.

- o poço na universidade. Temos pensado sobre a pesquisa como possibilidade de ser o lugar onde jogamos o balde para 
recolher fios de água. Temos pensado também até que ponto isso é possível através das produções universitárias, se elas forem resultado de pesquisa cuja necessidade do pesquisador seja exterior a ele, desencadeada pelo imediatismo das circunstâncias políticas ou econômicas. Por exemplo, a titulação desenfreada por valores institucionais. Temos visto que não são raras as vezes em que encontramos pesquisadores que vivem outra angústia, outro inferno: o de inventar uma pergunta de pesquisa que pode eliminar o necessário inferno da escrita a que nos referimos neste volume. Observamos que a superficialidade da pesquisa, sem implicação do pesquisador, facilita $\mathrm{o}$ ato de escrever e a suficiência da convocação de autores através das citações e pode rebaixar a escrita à condição de mercadoria, e ainda gerar a produção em série e provocar a estranheza do pesquisador diante do seu texto.

No diálogo com uma professora universitária, perguntei a ela sobre o doutorado, sobre o envolvimento com a pesquisa. $\mathrm{E}$ ela me respondeu que teria que finalizar, mesmo sem vontade, aquele curso, porque não tinha como continuar com o mesmo salário. Percebo que, nesse caso, dificilmente o poço pode ser experimentado, porque, sem implicação do pesquisador, será suficiente um recorte da realidade, uma descrição da porção que se mostra nos fatos a serem descritos e a suficiência de autores citados.

A implicação do pesquisador é condição para este necessário inferno da escrita, porque é o que vai favorecer o retorno de um balde jogado com cada vez mais força. O constante retorno é a persistência de trazer à tona aquilo que a realidade (a parte que se mostra nos recortes) sombreia do que não se revela: o real. Se o pesquisador, no inferno da escrita, delira diante da sombra do real, do reflexo de um sentido que tenta capturar, ele foge às regras de cultura e não realiza a escrita universitária. Mas, mesmo o pesquisador implicado, deverá 
viver o inferno de equilibrar o delírio diante do reflexo, um equilíbrio entre o que é possível dizer diante do indizível. Se o pesquisador não está envolvido, ele jamais se sentirá diante do ato de cometer o necessário crime contra as expectativas alheias, assumindo o delito de, pela criação, destruir, em parte, o já-produzido, como pondera Barzotto (2011). Sem implicação, o pesquisador jamais se sentirá encorajado a ferir o que já está aprovado para avançar com o novo e, com implicação, ele não poderá esquecer que essa destruição é em parte apenas.

A experiência do poço, na universidade, é também necessária para um delírio que mova a vida acadêmica feita por uma pesquisa cheia de sentido. Um delírio que não perca de vista as regras de cultura, mas não morra por causa delas. Sinto que esse inferno de escrever as produções universitárias só pode acontecer para criar o novo, quando o pesquisador, movido pela curiosidade apaixonada, guerreia com essas regras e consegue o máximo possível estar, a partir delas, acima delas, num lugar próprio que chamamos aqui de singularidade.

\section{LIÇÕES DA MANADA}

Durante a pesquisa, sentia que se agravava o meu processo de escrita. Quem sabe fosse possível pensar que, quando pesquisamos sobre o processo de escrita e analisamos textos escritos e conversamos sobre essas produções, finalizássemos uma investigação com a garantia de escrever bem. Engano. Com outras lentes, sei que trago incorporado um discurso que recebi também dos manuais científicos, das leituras terceirizadas, contra as quais tenho lutado. Por mais que saiba que uma produção acontece ou deveria acontecer a partir de uma lente paradigmática que passa a ser um olhar incorporado que dá uma visão de um mesmo mundo - entretanto, diferente - , fico sem saber 
onde me colocar no meu texto, mesmo recebendo a orientação de que tenho que produzir um texto para chamar de meu.

E o que é mais contraditório: por mais que não estivesse tendo acesso a nenhum daqueles manuais durante o doutorado, nem nunca isso ter sido cogitado, jamais pensei tanto sobre a escrita lendo sobre outras coisas. Por exemplo: nunca algo desestabilizou tanto o meu ato de escrever quanto a diferença entre real, aquele lugar que só se insinua no susto de alguns momentos, e a realidade, aquele outro que a gente vai inventando com a linguagem que nos barra.

Outro exemplo: nunca algo me fez procurar tanto as minhas necessidades quanto a noção de sujeito que só se reconhece através das referências e que agora está consumido pelo imediatismo de suas ações submetidas ao mercado. Nunca me desestabilizou tanto a perspectiva de construir um objeto em vez de re-apresentá-lo.

Esse agravamento dos meus atos de escrita tem-se dado exatamente por esse processo da aquisição de novas lentes, no qual o que gera é o que não vai chegar; é a ausência de alvo, esse momento confuso entre o discurso das garantias e um outro pelo qual o que se produz é a perda delas. Estou falando das produções universitárias através da minha experiência com que arrasto as dificuldades de encontrar um lugar para a singularidade se expressar. A única coisa que sinto é que a desordem é mesmo necessária para um cientista criador dar a resposta que, se não for por ele, jamais chegará. Sobre isso, meu orientador sugeriu o seguinte:

Escuta várias vezes aquela música de Caetano, aquela música que diz: "vaca profana, põe teus cornos pra fora e acima da manada" (Veloso, 1986, f. 1). Escuta várias vezes essa música... 
Escutei e pensei ainda mais, através dessa letra, sobre as condições ontológicas de um trabalho que se objetiva na escrita:

[...] respeito muito minhas lágrimas./ Mas ainda mais minha risada./ Inscrevo assim minhas palavras/ $\mathrm{Na}$ voz de uma mulher sagrada/ Vaca profana, põe teus cornos/ Pra fora e acima da manada [...]" (Veloso, 1986, f. 1).

Esta lição que eu denomino, desta vez, de Lições da manada acaba sendo o avesso das Lições do poço. Nesta, a questão do pesquisador era a imersão. Nas lições da manada, a hora é agora: de emergir. Vir à tona é produzir um texto próprio, resultado do que é humanidade - "bicho inteiro", a manada; resultado de não se deixar diluir totalmente na compressão da imagem do rebanho.

Trago na experiência da arte, o que Dufour (2005, p. 120) chama de "experiência total, uma questão que não aceita limites, não aceita ser estabilizada ou reduzida”. Amplio a experiência da pesquisa não só pelo comparecimento dos autores, mas do pesquisador que vai gerar o trabalho final, fruto de sua escrita, e lembro que foi em Guimarães Rosa (1984, p. 48) que eu li: "Olha, o que eu entendo das pessoas, foi com o traquejo dos bois que eu aprendi [...]".

Ele trata o traquejo dos bois como metáfora e aqui acrescento para a plena visão do que acontece dentro e fora das produções universitárias - no âmbito da pesquisa:

[...] dentro da multidão movediça há giros estranhos, que não os deslocamentos normais do gado em marcha - quando sempre alguns disputam a colocação na vanguarda, outros procuram o centro, e muitos se deixam levar, empurrados, sobrenadando quase, com 
os mais fracos rolando para os lados e os mais pesados tardando para trás, no coice da procissão. [...]. [...] Pouco a pouco, porém, os rostos se desempanam e os homens tomam gesto de repouso nas selas, satisfeitos. Que de trinta, trezentos ou três mil, só está quase pronta a boiada quando as alimárias se aglutinam em bicho inteiro - centopeia —, mesmo prestes assim para surpresas más. [...]. E, agora, pronta de todo está ela ficando, cá que cada vaqueiro pega o balanço de busto, sem-querer e imitativo, e que os cavalos gingam bovinamente. Devagar, mal percebido, vão sugados todos pelo rebanho trovejante - pata a pata, casco a casco, soca soca, fasta vento, rola e trota, cabisbaixos, mexe lama, pela estrada, chifres no ar [...] (Guimarães Rosa, 1984, p. 37-38).

Penso que o trabalho objetivado pela escrita nas produções universitárias não está na estrutura ou no conteúdo do texto, mas nessa relação entre os nexos que fundam as ideações de uma pesquisa, na relação entre pesquisador, legado, objeto, incluindo na dimensão do legado tudo o que está no eixo da continuidade: a realidade com todo o prévio constitutivo das experiências do pesquisador, suas leituras, as lentes que provavelmente serão trocadas, tudo o que, sob a metáfora de Guimarães Rosa, faz a boiada. Incluo também tudo o que move o pesquisador: a finalidade posta, suas necessidades que não devem se confundir com satisfação imediata, nem burocrática.

Mas pôr "os cornos pra fora e acima da manada", quando a boiada "já se aglutinou em bicho inteiro", é o grande desafio da pesquisa, "mesmo prestes assim para surpresas más”. Repensar essa teleologia secundária própria do trabalho intelectual é uma porta de acesso para uma escrita que nos obriga a trabalhar. 
Quem sabe assim inscrevamos nossas palavras, na difícil tarefa de nos deixar falar a partir do outro, ao invés de deixar que apenas o outro fale através de nós. É uma condição ontológica do novo condicionado à singularidade fundante da reprodução social pela produção do conhecimento. 


\section{A escrita normal e as certezas do pesquisador}


Para pensar as produções universitárias, contextualizamos as monografias, dissertações e teses ao conceito de ciência, porque o âmbito científico interfere em sua escrita. Esse conceito é quase sempre ligado à atitude de neutralidade. Talvez o leitor que agora esteja lendo esta afirmação possa se julgar diferente, mas, diante de uma situação que lhe exija ser científico, todo perfil de cientificidade que lhe parecia esquecido emerge pelas sensações ilusórias de um olhar cristalizado diante de um conhecimento pronto para ser capturado.

Isso provoca a falsa autonomia do objeto aos olhos do pesquisador, engaiolado que parece estar na posição desafiadora de quantos queiram capturá-lo. Não é raro ouvir dizer que o objeto, num determinado momento da pesquisa, devora o pesquisador. Tanto que muitos morrem devorados por ele e não finalizam a pesquisa.

Detemo-nos agora a esse caráter científico que deve compor o perfil dos pesquisadores. Não estamos questionando essa existência cobiçada pela humanidade, mas sim pensan- 
do sobre os limites dela. Estamos suspendendo esse caráter de cientificidade para, em certa medida, vislumbrarmos o tom encantatório que gera a audácia da captura do conhecimento, como se ele estivesse pronto. E o objeto parece que se esconde às sombras das inteligências, as quais precisam encontrar, entre os teóricos, alguma saída para representá-lo. Eis a também não rara visão fantasmagórica do objeto de pesquisa. $\mathrm{E}$ pensamos que assim tem sido porque, em todo o processo, o pesquisador seria aquele autorizado pelo saber para ir no lugar onde o seu objeto de pesquisa se esconde.

Os manuais científicos têm colaborado para construir essa visão, através de princípios básicos da pesquisa científica. Há os que consideram que os princípios devam ser os mesmos em qualquer ramo do saber. Pensam que a pesquisa científica, esta que dota o pesquisador de um caráter científico e, consequentemente, a sua produção, deva constituir "um processo consciente e racional de aprendizagem, destinado a promover a compreensão e explicação de determinados fenômenos de interesse coletivo com a finalidade de interpretação, previsão e controle" (Leite, 1978, p.14). O mesmo autor explica que o sentimento de incapacidade do pesquisador para "executar tarefa de tão alto nível" é "fator positivo", porque "promove a humildade e a isenção com que o pesquisador ou cientista deve abordar o estudo de qualquer questão", processo que deve ocorrer através da redução de incerteza (Leite, 1978, p. 2).

Essa visão se cristaliza também na ideia de que a redação científica deve ser clara, precisa, objetiva e consistente, com tom impessoal e que se deve optar pelo uso da voz passiva, porque "evita a referência repetida aos autores do trabalho" (Santos; Noronha, 2005, p. 25-26). Outra publicação chama atenção para a "necessidade de um manual que reúna as normas fundamentais" para a escrita de textos científicos (Rey, 1997, p. 1). 
Mesmo com todas as instruções necessárias, presentes nos manuais que orientam a escrever as produções universitárias, ainda assim muitos pesquisadores são devorados pelo objeto de pesquisa. É o momento que chamamos de desconfiguração: o pesquisador não se reconhece como tal porque o objeto some. Nesses manuais, encontramos, além de algumas considerações sobre o teor científico, modelos a serem seguidos.

É "uma imagem de ciência que nos domina, recebida dos manuais que cada geração utiliza para aprender seu ofício. [...] Esses livros nos têm enganado em aspectos fundamentais" (Kuhn, 2007, p.19). Eles contêm uma metodologia ilustrada por coleta de dados juntamente com “operações lógicas utilizadas ao relacionar esses dados às generalizações teóricas desses manuais" (Kuhn, 2007, p. 20). Isso resulta na imagem de ciência normal, empregada pela maioria dos cientistas, "baseada no pressuposto de que a comunidade científica sabe como é o mundo" (Kuhn, 2007, p. 24). A ciência normal, inevitavelmente, gera a escrita normal.

\section{UM DADO DA CIÊNCIA NORMAL NA LITERATURA}

Recorremos à literatura como dado para exemplificar, através de um conto de Machado de Assis, "Ideias de Canário" (Moraes, 1997, p. 165), um cientista no pleno exercício da ciência normal. O personagem se chama Macedo, "um homem dado a estudos de ornitologia". Ele conta aos amigos o episódio que havia sucedido a ele. A seguir, a paráfrase:

Indo por uma rua, sucedeu que um tílburi à disparada, quase o atirou ao chão. Escapou saltando para dentro de uma loja de belchior. [Nada] fez levantar o dono do negócio, que cochilava no fundo, sentado numa cadeira 
de abrir. Era um frangalho de homem. [Na loja] escura, atulhada de coisas velhas, tortas, rotas, enxovalhadas, enferrujadas, [havia] uma gaiola pendurada da porta. [...] Dentro pulava um canário. [Muitas hipóteses Macedo levanta sobre o canário que este imediatamente refuta, dizendo]: - Quem quer que sejas tu, certamente não estás em teu juízo. [Uma das hipóteses é a de que o dono da loja era o dono do pássaro. Sob outra ótica, era] seu criado. [Disse o canário]: - [...] Em verdade se o mundo é propriedade dos canários, seria extravagante que eles pagassem o que está no mundo.

Macedo era um pesquisador. Naquele momento de encontro com seu objeto de pesquisa, colheu o primeiro dado: o conceito de mundo. "O mundo é uma loja de belchior, com uma pequena gaiola de taquara, quadrilonga, pendente de um prego; o canário é senhor da gaiola que habita e da loja que o cerca. Fora daí, tudo é ilusão e mentira".

Macedo o leva para casa. Era seu "intuito fazer um longo estudo do fenômeno, sem dizer nada a ninguém, até poder assombrar o século com a sua extraordinária descoberta. [...] Feita a análise filológica e psicológica, entrou propriamente na história dos canários, na origem deles, primeiros séculos, geologia e flora das ilhas Canárias [...]”. Macedo, depois de ter trocado o canário de gaiola, que passou a ser "vasta, circular, de madeira e arame, pintada de branco", pendurada na varanda, "donde o passarinho podia ver o jardim, o repuxo e um pouco do céu azul", esperou a repetição do conceito de mundo para inserir seu dado, mas colheu outro, diferente do primeiro: “o mundo é um jardim assaz largo com repuxo no meio, flores e arbustos, alguma grama, ar claro e um pouco de azul por cima; o canário, dono do mundo, habita uma gaiola vasta, branca e circular, donde mira o resto. Tudo o mais é ilusão e mentira”. 
Macedo percebe que "não podia ainda escrever a memória que havia de mandar ao Museu Nacional, ao Instituto Histórico e às universidades alemãs, não porque faltasse matéria, mas para acumular primeiro todas as observações e ratificálas". Macedo fica "enfermo". "Era excesso de estudo, não devia ler nem pensar, não devia saber sequer o que se passava na cidade e no mundo". Depois do repouso, toma conhecimento de que o canário tinha fugido. Sumido estava seu objeto de pesquisa. Ele "tinha já recolhido as notas para compor a memória, ainda que truncada e incompleta”, quando, de visita a um amigo, que vivia "numa das mais belas e grandes chácaras dos arrabaldes", reencontrou o canário que "estava no galho de uma árvore". Macedo, naquele momento, colhe o seguinte dado: "O mundo, conclui solenemente, é um espaço infinito e azul, com o sol por cima". Macedo ficou indignado e "retorquiu-lhe que, se lhe desse crédito, o mundo era tudo; até já fora uma loja de belchior [...]".

Alguns fatos nos chamaram atenção. O primeiro, a forma acidental que determina a escolha do objeto pelo pesquisador. Ele "escapou saltando para dentro de uma loja de belchior". O segundo, a loja ser de belchior, "escura, atulhada de coisas velhas, tortas, rotas, enxovalhadas, enferrujadas", onde havia "uma gaiola pendurada da porta". A única possibilidade de voar estava aprisionada. O terceiro: o pesquisador analisa o dado numa momentânea situação de interlocução. Ele o cristaliza no primeiro conceito de mundo mediado por um contexto específico.

Em vista desses fatos, inferimos que, quando o pesquisador escapa, ou seja, define acidentalmente o objeto, ele cai num espaço envelhecido e enferrujado, e passa a eliminar o impulso pelos critérios de isenção. No processo, o próprio objeto é que parece escapar, porque o pesquisador, com as suas práticas de cientista normal, torna-se tão envelhecido quanto 
o espaço onde ele caiu. Parece escapar porque, se o objeto não foi produzido, ele ainda não existe. Enquanto o pesquisador escapa e se perde no mundo cuja dimensão é a gaiola, o objeto escapa e se liberta no espaço azul e infinito à espera de um pesquisador que produza o conhecimento, sem considerá-lo já-produzido.

São aí revelados os problemas da "ciência normal": "determinação do fato significativo, harmonização dos fatos com a teoria e articulação da teoria” (Kuhn, 2007, p.55). No primeiro caso, o fato acontece fora da escolha do pesquisador - é acidental; no segundo, a teoria é pensada a partir do objeto com elementos para descrevê-lo, representá-lo e não para construílo; e, no terceiro, se os elementos são descritos e a teoria não é usada como lente através da qual o objeto vai ser produzido, há o retorno para a queda acidental do pesquisador numa loja de belchior.

Mas, sob o ponto de vista mais geral, o grande drama do pesquisador é o de que ele toma como tese um dado colhido numa situação imediata, descrevendo-o por um conceito construído numa situação específica, sem levar em consideração o contexto sócio-histórico que abarcaria as mudanças como indício para ler, com as marcas da exterioridade, o discurso ali manifesto. $\mathrm{O}$ que provocou a perda deveria ter provocado a produção do conhecimento. Uma desorientação favorável que, quando acontece, "começam as investigações extraordinárias que finalmente conduzem a profissão a um novo conjunto de compromissos, a uma nova base para a prática da ciência" (Kuhn, 2007, p. 24). Com isso, haveria ali a possibilidade de revolução pela atitude de um outro perfil de cientista. Mas onde o conto de Machado termina, não dá para garantir que há a morte do pesquisador pela produção do mesmo ou o salto para a produção do novo. O certo é que até aí a escrita é realizada através de notas. $\mathrm{O}$ pesquisador fica à espera das certezas para iniciá-la. 
Encontramos, num manual científico (Santos; Noronha, 2005, p. 25), um capítulo que levanta a necessidade de clareza, objetividade e concisão com a seguinte epígrafe de Clarice Lispector (1991, p. 19): "Escrever é uma pedra lançada no poço fundo”. Dessa contradição entre o que é garantido e o que jamais será no tocante ao conhecimento, tomaremos a direção a partir de agora. Levamos em conta os cientistas criadores, que vivem em "um mundo desordenado" e precisam da "tensão essencial” implícita na pesquisa científica (Kuhn, 2007, p. 109).

A ideia de ciência criadora (Kuhn, 2007, p. 109) foi retirada como possibilidade de fazer um contraponto com a de ciência normal e realizar a transposição para a ideia de escrita normal. Não entramos mais profundamente aqui no sentido de ciência criadora sob a ótica do referido autor, tanto que o conceito para contrapor a escrita normal é o de escrita laborativa. Pensamos numa escrita que enfrentasse um mundo desordenado num contexto possível para pensar o conhecimento "não mais através de seus produtos, mas de seus processos".

Neste viés, o objeto é construído e não representado. Isso altera o enfoque do ensino para uma atitude investigativa, sem privilegiar o "ensino transmissivo", constituído de "milhares de professores fazendo conferências para milhões de ouvintes passivos, que pouco ou nada vão aproveitar do que estão ouvindo" (Severino, 2007, p. 24-33).

Colocamos duas perspectivas: a de escrita normal fundamentada na ideia de "ciência normal" e a de escrita laborativa inspirada na hipótese de se poder chegar a uma "ciência criadora" intermediada pela possibilidade de produzir o objeto de pesquisa, não de representá-lo. Consideramos identificado o ponto desconfortável da escrita das produções universitárias: a ideia de produto a ser apreendido por uma ideologia peda- 
gógica dos já prontos e a incapacidade de capturá-lo gera a angústia de se achar incapaz de produzir o texto próprio, singular, por causa da sensação de que o objeto está à espera do pesquisador para reproduzi-lo. Mas não está. Não esqueçamos que o objeto é uma hipótese, uma sombra, um reflexo.

Tomamos a direção de uma escrita que produza conhecimento sem se limitar a ser produto. Uma escrita que objetive as produções que ela, ao mesmo tempo, veicula e não se reduza a produto para transitar na burocracia universitária, cumprindo outras necessidades mais redutoras ainda do que o ensino visto sob a perspectiva transmissiva. Uma escrita pela qual o pesquisador assuma a desordem de sua ignorância no processo da produção do conhecimento. Uma escrita laborativa, pensada, filosoficamente, sob o conceito de trabalho.

\section{INTERFERÊNCIA DO CONTEXTO SÓCIO-HISTÓRICO NAS PRODUÇÕES UNIVERSITÁRIAS}

A escrita no âmbito do que está tratado como ciência normal é produzida sob a expectativa das orientações presentes nos manuais científicos ou sob o que está cristalizado pelo contexto universitário construído de "milhares de conferências" a alunos passivos. Além disso, ela sofre interferências do contexto, motivo que nos levou a decidir abstrair sobre essa certa atmosfera que a envolve, na medida em que afeta quem produz na universidade.

Diante desse legado, julgamos importante, para pensar os desdobramentos dessa expectativa, contextualizá-la não só para localizar as produções na universidade, mas esta, no contexto sócio-histórico maior. Tomaremos como referência este momento ultraliberal, pós-moderno. Ao construir uma entre as tantas possibilidades, expomos a lógica que nos propomos seguir: primeiro, o tempo é o momento e o momento, o con- 
texto - este, com o qual nos defrontamos agora. Nele vivemos a narrativa da perda, da ausência de grandes sujeitos, a orfandade de fronteiras. No plano político, nenhuma grande espera e, no econômico, a lógica do mercado.

Estilhaçando a história e estilhaçados pela ausência dela, não sentimos falta da falta, porque ela é primordial; sentimos falta do que a tamponava: as imagens da cultura que nos moviam para algum lugar de onde sempre era possível vislumbrar um futuro. Caminhávamos na direção da felicidade prometida. O que chegou foi o caos. Sentimos falta dos paliativos, porque a grande narrativa não disfarça a falta, mas a coloca no centro como condição quase irremediável. As produções universitárias não passam impunes por essa situação, porque o pesquisador não está imune a esse mal-estar contemporâneo.

Está desgastante repetir a lição desanimadora deste tempo, mas, neste momento, julgamos necessário pensar sobre ela, porque é uma visão da exterioridade que os dados podem manifestar. Se virar discurso, então sedimentaremos tudo isso com a desculpa para nossa espera, para a responsabilização do outro, para os desvios que cavamos frente às finalidades. Nós passamos por elas como se não fizéssemos questão de encontrá-las no amanhã. $O$ futuro não existe como direção, o passado não nos interessa, porque a grande narrativa que move a humanidade é o presente.

Quando está dessimbolizada a história, não só nos perdemos das referências, como fragmentamos o tempo. E o aqui-agora e as consequências desse posicionamento são desastrosas para a simbolização. Dessimbolizamos a noção de compromisso e ferimos as necessidades e as escolhas entre as alternativas que temos. Cristalizamos o conhecimento e nos burocratizamos.

Olhando a linearidade do tempo, no início, o homem se orientou a partir da referência aos mitos, depois a Deus, de- 
pois à razão... Em outra perspectiva, outros sujeitos passaram a orientar a humanidade: a república, o povo, a raça. Hoje, um outro "grande Sujeito": o capital. Estão afetadas as nossas finalidades e dessimbolizado está tudo aquilo que decorre das referências, até as consequências últimas da diluição de nós mesmos e do que fazemos (Dufour, 2005, p. 67).

Podemos dar um exemplo: se as referências do pesquisador estão fragmentadas, fragmentado também estará o sentido da pesquisa e distorcidas as suas finalidades. Existirá uma medida em que tudo isso compromete a produção universitária como objetivação do processo de produção de conhecimento. Costumamos ler e dizer que os paradigmas se quebraram e que estamos sem referência. Mas pensamos que esteja cada vez mais claro que a nossa referência é o mercado ou o capital como o grande Sujeito em torno do qual nos movemos para alimentar (Dufour, 2005).

Atentos ao discurso dos pesquisadores quanto à finalidade de suas pesquisas, é quase unânime a qualificação como exigência de mercado. Qualquer outro sentido geralmente é secundário. Se são essas as prioridades, chega o momento de entendermos o sentido de não mais pensarmos que estamos consumindo ou que somos consumidores.

Muito mais já é possível dizer: estamos consumidos pela lógica de mercado, quando, necessitados do título para o incentivo salarial, revelamos não saber qual é mesmo o lugar da nossa paixão no processo de nossa pesquisa e, em consequência, o nosso espaço nas nossas produções universitárias. Soma-se à cristalização provocada pelos fundamentos da ciência normal, a definição das necessidades do pesquisador pela ótica mercadológica criada para as políticas universitárias. Mais uma interferência que pode ferir profundamente a escrita do pesquisador.

Nos diálogos com pesquisadores que estão produzindo seus textos, o inferno da pesquisa aumenta, não só pela an- 
gústia de escrever, de confrontar-se com a realidade tentando ultrapassar para o real, nem pela desconfiguração do objeto de pesquisa, por ser fruto da expectativa de acessar o conhecimento como produto e não como processo, mas também muitas vezes pela dessimbolização do próprio objeto estranho ao pesquisador, face também à finalidade priorizada. Se a finalidade da pesquisa é, sobretudo, o aumento salarial, a escolha da pesquisa também sofrerá suas consequências.

Uma das consequências das finalidades imediatistas para a pesquisa é a dessimbolização da teoria, quando ela não é recebida como exemplar de um paradigma - alguma lente (Kuhn, 2007, p. 149) - através do qual o mundo se reconfigura. Por exemplo: temos observado que o autor é citado de forma equivocada, fragmentado nas citações exigidas pelos manuais científicos (Kuhn, 2007, p. 176) para a produção universitária, numa leitura muitas vezes terceirizada. Importa que haja teoria para a análise dos dados. Mas, em função das circunstâncias em que a pesquisa se estrutura, não há escolha para o pesquisador aceitar ou não uma teoria e, restringindo ainda mais, escolher um autor, para participar da construção do objeto com lentes apropriadas. Isso gera a fragmentação da lente, esta tão necessária ao sentido da pesquisa e aos efeitos desse sentido na escrita do pesquisador. 


\section{Produções universitárias entre outras instâncias da escrita}


A escrita se dá em diversas instâncias: ela pode ser um instrumento utilitário, servindo mesmo de prótese para a memória; pode intermediar uma relação intrapessoal, na relação eu-mim, através de anotações, rabiscos, diários. Pode se estabelecer como ponte entre Eu/eu; Eu/tu; Eu/todos/o mais público; Eu/o universal. Entre essas instâncias, a escrita vai se estabelecendo das finalidades mais imediatas, mais pessoais, às finalidades mais genéricas e universais, podendo chegar até a produção do novo e a transmudação do eu (informação verbal). ${ }^{5}$

Localizamos as produções universitárias entre a ultrapessoal, de natureza oficial, onde o eu é neutralizado pelas relações burocráticas, e a escrita literária, suprapessoal, onde o eu é transmudado pela arte para a esfera da humanidade. No primeiro caso, estão, por exemplo, os documentos oficiais, es-

5 Discussões da disciplina EDM 50640, ministrada pela Prof. ${ }^{a}$ Dr. ${ }^{a}$ Claudia Riolfi, durante o $2^{\circ}$ semestre de 2007. 
paço de total apagamento do sujeito. No segundo, a literatura, quem escreve se dirige para a humanidade na condição de ser.

$\mathrm{Na}$ universidade, o pesquisador escreve na condição de cientista e a escrita pode se configurar como suprapessoal, quando há a entrega da singularidade à universalidade ou como ultrapessoal, neutra, quando a atitude de escrever assume um caráter oficial, burocrático. Só sendo pressionado pelo reflexo, o pesquisador parte do que não se escreve, e as produções universitárias podem realizar uma escrita regulada pelo escrito, não permanecendo na neutralidade.

Não se trata de oscilar entre o científico e o literário. Este se dá no plano da estética onde o ser se manifesta diante da vida e aquele está na dimensão da ciência que pode assumir um perfil de ciência normal ou de ciência criadora. As produções universitárias, com vistas à produção de conhecimento, contêm seu lado de ficção, são criações e o real dá sinais, manifesta-se na produção do pesquisador quando o recorte é consequente de sua invenção.

A condição de pôr-de-si nessa escrita laborativa não está condicionada ao estilo, mas ao que se configura como resultado de suas finalidades que deverão estabelecer outra possibilidade: a de galgar dimensões do interesse do gênero humano. Em síntese: não é o dilema entre científico e literário que aponta, na escrita, para o caminho da singularidade, origem da possibilidade de ser afetado pelo real que dá sinais de sua existência, mas a relação entre o singular-individual-subjetivo e o particular-genérico-universal que deve se manifestar nas produções universitárias.

Localizamos também aí o dilema do grau de neutralidade exigido nessas produções e até onde isso é possível, lembrando que a solução da neutralidade tem sido, em grande incidência, um outro autor, não como momento de continuidade, mas de repetição. Aí está a negação das produções universitárias 
como trabalho pensado na perspectiva ontológica do "ser social", onde a subjetividade é um momento fundante dessa categoria, mas não pode ser o ponto de chegada.

Ao dizer que a ida ao campo do outro é sistematizada, a única alternativa é reproduzir; ao considerar essa ida sistematizável, escrever passa a ser enfrentar o caos e, através da escolha entre alternativas, responsabilizar-se pela produção. Nesse sentido, escrever é inventar, desde que haja a superação do pesquisador como sujeito da repetição.

Quanto mais o saber é considerado organizado, mais se dá a cristalização e a escrita será impessoal e compacta: uma escrita normal. A ida ao outro é necessária, mas a escrita tem que balizar o limite entre o continuum e o que virá depois dele. Para que o pesquisador realize uma escrita suprapessoal, ele terá que avançar da tradução, alimentar a escrita da falta fundamental para enfrentar o reflexo e construir outra coisa ainda não existente.

Ao abstrair o conceito de trabalho das produções universitárias e, destas, as posições teleológicas do pesquisador diante do já-existente para produzir o que ainda não existe, estamos nos referindo às ações em torno de um objeto de pesquisa, estamos também considerando a escrita em seu processo. Diante dele, o que o pesquisador vê não é o objeto em si, mas sua sombra, a hipótese.

Partimos do princípio de que ele ainda não existe sob o olhar daquele pesquisador, porque essa sombra, chamada na ontologia de "reflexo", "uma realidade própria da consciência" (Lukács, 1981, p. 16), será delineada a partir do já-produzido sobre o objeto, para que o pesquisador tenha alguma base com que criar outra impressão diferente das que já existem. 
Diante do "reflexo", há uma luta para a produção do objeto e o pesquisador o faz através ou de ideações que ele põe a partir de relações concretas ou de ideações já elaboradas por outros, permanecendo na condição de receptáculo de informações verdadeiras sobre o objeto que se porá a reproduzir. Essas produções acontecem através de um trabalho de escrita, neste momento pensado em seu processo e possibilidades.

Significa que, diante do objeto, o processo de pesquisa resulta em escrever que, por sua vez, pode acontecer por duas vias: ou o pesquisador tenta reproduzir o objeto, fiel ao que já está produzido sobre ele, ou se confronta com o reflexo a partir do já-produzido e constrói uma "impressão" ainda não existente.

Reproduzir o "reflexo", fiel ao que já está produzido sobre ele, confere ao pesquisador o exercício da "representação do conhecimento" e não da "produção" (Severino, 2007). Resulta também na homogeneização que compromete a reprodução social do mundo dos homens que se dá pelo trabalho, impedindo o movimento do mundo pelo mover da vida que passa a permanecer fixada no mesmo. Os dois atos dos quais estamos falando são: de um lado, "o reflexo o mais exato possível da realidade [...]; de outro, o correlato pôr daquelas cadeias causais que, como sabemos, são indispensáveis para realizar a posição teleológica" (Lukács, 1981, p. 36).

Mas estamos associando "reflexo" (Lukács, 1981) a "real" (Lacan, 1998b). Ele corresponde ao ângulo do objeto que não se mostra, apenas em alguns momentos se manifesta e, portanto, não se escreve, porque "é o próprio escrito em sua diferença para com o significante", ressaltando que "[...] o estatuto é real e não simbólico", visto que [...] "o real aparece como o excedente' e o escrito nunca se escreve" (Zizek, 1991, p. 67-68).

A atitude de escrever que se restrinja à escrita como produção necessária à representação do conhecimento não exige 
do pesquisador o desafio de ir para além dos rituais próprios de um modelo exigido; não exige dele o embate diante de um reflexo, nem uma angústia que vá além do suprimento da necessidade de reproduzir as informações recebidas, próprias de um sistema de ensino ou do cumprimento de uma tarefa burocrática. A atitude de escrita como reposição do já-existente que "regula a escrita pelo sentido" está no âmbito da tradução (Allouch, 1995, p. 16). É o que estamos considerando de escrita normal das produções universitárias.

Quando pensamos a escrita como uma atitude de traduzir, relacionamo-la à atitude de repor o mesmo. Nesse caso, escrever é uma ação tomada como produto de manobras linguísticas com base numa organização de fragmentos da realidade e de dizeres dos autores num todo coerente. As produções universitárias, consequentes de uma escrita tomada como produto de uma organização de dizeres prontos sobre um objeto, de forma coerente, são consideradas a partir de elementos constitutivos do sistema linguístico e textual e da informação com base no âmbito do conteúdo.

Estamos nos referindo a uma escrita que acontece no reino da certeza, onde não há espaço para enfrentar o reflexo. Quando o pesquisador está no limite do texto como produto, ele se detém entre a materialidade e o conteúdo e, geralmente, tem o olhar para a realidade e não para o real ou o reflexo; para a escrita e não para o dilema do escrito na escrita. Essa produção permanece no nível da imediatidade sem tempo nem disposição para se alimentar da falta de onde algo se cria, a falta que é do próprio objeto que precisa ser inventado pelo pesquisador.

Depreendendo a noção de trabalho dessas produções realizadas por uma escrita suficiente, reprodutora dos conhecimentos prontos, tal como pode ser esperado numa universidade que se funda no ensino transmissivo, percebemos que 
são eliminados os nexos a que está condicionada a singularidade e, em consequência, a produção do novo a que também se condiciona a reprodução social.

Esse tipo de escrita não está centrada no objeto, mas num autor, elimina a dimensão do reflexo para que o real se manifeste, porque este está do lado do objeto. A produção universitária elimina a heterogeneidade que faz a linguagem propícia ao novo, que é simbólico, ao repor informações colhidas no ensino como forma de comprovar a aprendizagem dos ensinamentos recebidos.

$\mathrm{Na}$ medida em que a universidade promove a circulação de produções resultantes de uma escrita normal, tal como mercadorias produzidas para circulação e consumo, a produção de conhecimento não acontece na dimensão ontológica da reprodução social e o movimento gerado pela continuidade é negado, gerando uma particularidade fixa e imobilizada, espaço próprio para a eliminação do "impulso" (Lessa, 1997) ou da "pulsão" para criar, o que resulta num tipo de discurso sedimentado na satisfação imediata de uma escrita normal, fora do espaço da angústia.

PRODUÇÕES UNIVERSITÁRIAS: POR UMA ESCRITA DO ESCRITO

Partindo do princípio de que o "real" apenas se manifesta em alguns momentos, mas não se mostra e que "o escrito está do lado do objeto, e, portanto, o estatuto é real e não simbólico" (Zizek, 1991, p. 67-68), localizamos o que não está do lado do pesquisador: o controle sobre a escrita.

Nas produções universitárias, escrever não basta. Não é suficiente produzir uma monografia, ou uma dissertação, ou uma tese, se o conceito de trabalho ali depreendido não corresponder a uma teleologia - causalidade e finalidades - a qual possa promover algo de emancipação de um pesquisador 
autêntico. Porque o trabalho tratado sob a perspectiva ontológica corresponde a uma instância do novo que nutre a singularidade na reprodução social e promove a liberdade.

$\mathrm{O}$ acesso à universidade determina, no mínimo, quatro anos de uma carga horária distribuída entre disciplinas ministradas por professores que, muitas vezes, propõem a repetição das ideias dos autores que se põem a repetir. Acontecem as escritas em muitos níveis, mas, para que o escrito se inscreva do que "não se escreve" (Zizek, 1991, p. 67-68), é preciso que o pesquisador desafie o reflexo para criar o objeto. Para isso, outras instâncias fora do domínio do simbólico interferem e se manifestam nesse nível onde se processam as produções universitárias, espaço onde é exigido do pesquisador necessidades que não se restringem àquelas estritamente materiais, imediatas.

Uma das condições para o enfrentamento do pesquisador com o reflexo é um olhar movido por "impulso" ou "pulsão". Mas "esta pulsão ao devir-humano dos homens - independe de quando os homens sejam ou não conscientes da sua presença" (Lessa, 1997, p. 135). E esse movimento, esse sentimento do devir, relacionamos ao impulso de continuar sempre indo, indo sem parar. Isso é condição para que o ato de produção manifeste o unitário de quem o produz por determinação da finalidade, a partir de necessidades concretas pelas quais o pesquisador é movido também inconscientemente, mas apaixonadamente.

A "pulsão" é este momento oportuno de pensar as produções universitárias pelo contato entre o "ser social", o "sujeito de desejo" e o "sujeito do discurso". Acreditamos que a "pulsão" é o ponto de contradição que gera o "impulso" de continuar sempre, mesmo sabendo que não é possível chegar ao "real". E esse é o maior encanto: o de fazer algum caminho e ir sempre, sempre para algum lugar na trilha dos significantes que não 
dão conta de tudo, mas carregam sempre a repetição da falta, ou seja, o "real", que se manifesta no ato de produzir o que não está pronto. Talvez aí a paixão: a de portar o significante, mesmo sabendo que ele não contém o tesouro. Onde se preenche, a paixão falta.

Um pesquisador, determinado a escrever pela imediatidade, não estando movido pelo impulso, tem como resultado de sua produção o estranhamento, e não a identificação com o produto do trabalho e a entrega de sua participação à generalidade humana, ou seja, a alienação, segundo a Ontologia do Ser Social. Se o "real" está do lado do objeto, a "pulsão" está do lado do pesquisador e dela ele depende para seu enfrentamento no processo de criação. Isso implica que "impulso" e "pulsão" também são conceitos fundamentais para a produção do conhecimento e para a singularidade do trabalho objetivado pela escrita na universidade.

Quando inferimos que não basta que o pesquisador escreva para que ele produza conhecimento na universidade, estávamos também inferindo que a escrita pode não manifestar o "escrito" cujo "estatuto é real e não simbólico" (Zizek, 1991, p. 67-68). "O escrito nunca se escreve" (Zizek, 1991, p.67-68), mas dá sinais de sua presença. Para que a produção universitária possa manifestar o escrito, ela tem que ir além de uma escrita normal do eixo da "tradução" (Allouch, 1995, p. 16), que localizamos sob o olhar de uma "ciência normal" (Kuhn, 2007), para uma escrita criadora, resultado da "transliteração" (Allouch, 1995, p. 16). “Transliterar é escrever regulando o escrito no escrito" (Allouch, 1995, p. 16), ou seja, conduzir para outro lugar através da escrita e não permanecer no mesmo das repetições. 
Ao tratar as produções universitárias, estamos reafirmando a possibilidade de abstrair delas o conceito de trabalho e de localizá-lo na atitude laborativa de escrever. Significa que o trabalho delas depreendido manifesta-se na escrita. Nas produções, isso aconteceria se a universidade fosse o lugar propício à produção do conhecimento como produto com "valor de uso". Este resulta de um trabalho propício à reprodução de sua própria existência onde é possível o novo no ser social. E isso se dá através de uma "posição teleológica que dá origem a uma nova objetividade”, a um novo produto (Lukács, 1981, p. 38).

Ora, quando alguém se propõe a trabalhar, poderá ir por dois caminhos, a princípio: ele tem necessidades de que alguma tarefa repetitiva supra para ele necessidades subjetivas, pessoais, materiais e, equivocadamente, pensa que está trabalhando; ele cria teleologias, finalidades, possibilidades de escolher entre alternativas na realização de um trabalho cujo produto não gera retorno apenas para si, mas para a generalidade humana. No primeiro caso, ele vive a escravidão, mesmo que trabalhe pouco ou nada; no segundo, ele experimenta a liberdade, mesmo que o esforço que empreenda seja maior e mais intenso.

Pensamos então numa atitude de escrever que não se restrinja à escrita como produção necessária à representação do conhecimento, mas que exija do pesquisador o desafio de ir para além dos rituais próprios de um modelo exigido na universidade. Uma escrita objetivada no embate diante de um reflexo, na angústia que vá além do suprimento da necessidade de reproduzir as informações recebidas, próprias de um sistema de ensino ou do cumprimento de uma tarefa burocrática. Pensamos numa atitude de escrita que não se limite à reposição do já existente, que "regula a escrita pelo sentido" no âmbito da tradução (Allouch, 1995, p.16), mas que produza 
conhecimento, como meio e fim de um caminho de emancipação da genericidade humana.

Nesse processo, "o fim regula e domina os meios" (Lukács, 1981, p. 9). Mas, muitas vezes, a priorização dos meios (utensílios) é mais importante que a satisfação dos fins. A escrita vista como utensílio pode revelar sua própria história, conter um conhecimento novo, mas pode desvendar muitas informações sobre o contexto daqueles que a produziram, neste caso, a universidade. É, em função disso, que optamos por analisar as produções universitárias com vistas a um acesso à exterioridade de sua objetivação.

Indo aos meios que constituem a escrita, citamos como exemplo as palavras. Mas não só elas são meios para escrever. Incluímos aí a realidade, o objeto, o reflexo, o legado onde está toda a gama de conhecimentos produzidos, os conceitos, as teorias, os autores, os métodos de análise, todos são utensílios para o pesquisador chegar ao produto que é o conhecimento, que deve carregar, por uma condição ontológica, forte peso da invenção do pesquisador.

Para explicar melhor a posição teleológica sem deixar margem ao equívoco de priorizar o pensamento, localizamos o projeto de pesquisa como momento fundante das produções universitárias, que são objetivadas pela escrita. Toda pesquisa na universidade é objetivada no ato de escrever, mas começa num projeto: "todo processo teleológico implica uma finalidade” (Lukács, 1981, p. 20) e os objetivos são parte imprescindível desse projeto de pesquisa. "É um projeto ideal [que] se realiza materialmente", com "uma finalidade pensada [que] transforma a realidade material, insere na realidade algo de material que [...] apresenta algo de qualitativamente e radicalmente novo" (Lukács, 1981, p. 25).

Ainda aqui é importante levar em consideração que a finalidade e "a busca dos meios [são] de máxima importância para 
compreender o processo de trabalho, especialmente quanto a seu significado na ontologia do ser social" (Lukács, 1981, p. 8), a partir da qual analisamos o caráter laborativo das produções na universidade. Ainda nesse sentido, a causalidade é levada em consideração, porque é quem põe em movimento o processo de realização do trabalho.

Consideramos a escrita o lugar onde se reúnem os fins e os meios para a objetivação do produto que deve produzir um novo conhecimento. "Natureza e trabalho, meio e fim chegam, deste modo, a algo que é em si homogêneo: o processo de trabalho e, no fim, o produto do trabalho" (Lukács, 1981, p. 9).

Como o real é o lado que apenas se manifesta em alguns momentos, é a parte que não se escreve, a escrita como resultado de um trabalho de criação do objeto é também reflexo, quando vista sob a ótica da finalidade que é sempre uma finalidade iludida. Se ao final da escrita nas produções universitárias algo desse movimento tiver se manifestado, é porque houve a "transliteração", resultado de uma atitude de escrever que tira o leitor do mesmo para outro lugar.

Essa atitude de transliterar na escrita resulta de uma atitude de escrever que escapa ao trabalho como "um mero ato decisório", porque é "um processo de uma contínua cadeia temporal que busca sempre novas alternativas" (Lukács, 1981, p. 32).

Essa possibilidade de escolher entre alternativas funda o conceito de liberdade pelo trabalho. Mas isso só acontece se, a partir do sentido original do trabalho, a produção for pensada como valor de uso, "desencadeada pelas necessidades sociais" (Lukács, 1981, p. 39) e não pelas demandas particulares. Julgamos importante esclarecer que há necessidades concretas que determinam as atitudes laborativas e que elas são ontológicas, próprias do ser. Mas estabelecemos uma diferença entre as necessidades concretas e a satisfação imediata. Quando nos refe- 
rimos às produções universitárias, comparamo-las a trabalho primário por reconhecer que, por mais que as atividades laborativas se desdobrem para outros tipos de relações, ainda assim as relações primárias de trabalho são extremamente explicativas.

Entretanto, a possibilidade de abstrair a categoria trabalho das produções universitárias objetivadas pela escrita se dá pelo fato de haver desdobramentos do trabalho primário, através do qual "objetos naturais são transformados em coisas úteis". Tratamos das produções universitárias como posições teleológicas, próprias do trabalho intelectual, que devem produzir valores de uso, pela práxis social interativa, cujo "objetivo é convencer outros seres sociais a realizar determinado ato teleológico". Nesse desdobramento que não é derivação, mas maior complexificação do processo de trabalho, "palavra e conceito, linguagem e pensamento conceitual permanecem juntos como elementos [...] do ser social [...]" (Lukács, 1981, p. 49).

Quanto a isso, o trabalho interfere sobre a linguagem e o pensamento conceitual e vice-versa (Lukács, 1981). Localizamos então as produções universitárias como "posições teleológicas secundárias", que são momento de interação entre seres sociais, de que são exemplos a linguagem, a práxis política, a religião, a ética, a filosofia, a arte etc., as quais encontram o seu fundamento ontológico-genético a partir da esfera do trabalho. Mas a escrita dessas produções não é "descontinuidade e ruptura em relação às atividades laborativas”, elas acontecem como um "prolongamento complexificado (e não pura derivação) em relação ao trabalho". Significa que essas produções se realizam em "níveis mais avançados de sociabilidade" e se originam no trabalho primário entre ser social e realidade. Se os resultados materiais, imediatistas, forem a prioridade, então haverá uma inversão de valores na pesquisa e o comprometimento do sentido de universidade. (Antunes, 2007, p. 142) 
6. O pesquisador: um ser social sob a ótica da filosofia 
Pensamos que será em vão confrontar a escrita na universidade se continuarmos a considerar o pesquisador mera função universitária. Pensamos também que, por uma coerência à ideia de despositivizar, tal como sugeriu Mirian Warde, precisamos acordar a Filosofia para nos dar bases para rever o sentido da pesquisa que é resultado das repercussões dos sentidos de um trabalho de investigação para o pesquisador.

Acreditamos que, para que esse sentido chegue a repercutir uma escrita, este mesmo pesquisador há que se perguntar: em que medida eu acredito que, realizando esta investigação, estarei colaborando com o meu quinhão para produzir conhecimento e fazer universidade? Esta investigação contribui com a produção de conhecimento? Esta pergunta de pesquisa, mesmo sendo de interesse para a humanidade, provoca em mim a paixão necessária para eu poder chegar às camadas superiores e aparentes da escrita, trazendo do fundo do poço o que minha persistência me possibilitou ir recolher? O sentido desta pesquisa faz sentido para mim? Eu tenho uma pergunta 
de pesquisa ou caí acidentalmente nesta investigação tal qual o tílburi em disparada - do conto de Machado de Assis caiu na loja de belchior, deu de cara com um canário e queria que ele repetisse a mesma lição do início ao final do processo?

Acreditamos ainda que, se o pesquisador não se fizer estas e outras perguntas, estaremos caminhando para a total negação do novo que surpreende com a singularidade, com a continuidade que é partir do que existe com o que existe, para outra coisa, muitas vezes tão óbvia como estas perguntas que agora citamos, mas que são tão inerentes ao ser que ele até tem se esquecido de se perguntar, tal a configuração deste aterrorizante mundo novo.

Estamos abrindo esta saída por pensarmos que o novo é uma abstração necessária para investigar a produção de conhecimento na universidade, resultante das investigações do pesquisador em suas produções. E está relacionado às ações próprias do mundo dos homens de onde depreendemos o ser para analisar a pesquisa como um gesto fundador de algo que não seja a reprodução do mesmo.

Sendo assim, estamos aqui considerando o pesquisador como ser, como sujeito social interpelado por ideologias e por condições de produção na maioria das vezes coercitivas. Antes, pensando-o filosoficamente como ser social, pelos fundamentos da Ontologia do ser Social, para pensarmo-nos o mais dentro possível das nossas finalidades. Só assim poderemos submergir às camadas mais profundas das linhas das nossas monografias, dissertações e teses, sem ficar apenas nelas entre as nossas e as dos autores - aqueles que citamos.

Os princípios da Ontologia do ser social do filósofo Lukács revelam que este mesmo ser - todos nós, cada pesquisador - constitui-se de três esferas: a inorgânica, a biológica e a social. Pela primeira, o ser só pode tornar-se outro mineral; pela segunda, a possibilidade é a de repor o mesmo 
da reprodução da vida ou a de voltar à anterior, na morte. Só pela terceira esfera produzirá o novo e o fará sempre de modo teleologicamente orientado. Essas esferas possibilitam estabelecer um comparativo entre o que é possível avançar de uma reprodução natural, biológica, para uma reprodução social, hominizada pelas ações transformadoras construídas nos momentos da ruptura entre o que já existe e o que, acrescentado a um legado recebido, avança para outra coisa diferente do já-existente(Lukács, 1981).

Perguntamos, então, em qual esfera ontológica, ou seja, própria do ser, se põe o pesquisador: na segunda esfera, pela qual só é possível pôr o mesmo, ou na terceira, pela qual poderá produzir o novo? As atitudes expressas nas monografias, dissertações e teses poderão, de certa forma, responder.

Mas, filosoficamente, qual a condição do novo? O trabalho: a condição do ser social. Não o trabalho fragmentado pelo qual o trabalhador não se reconheça. Quais as determinações do trabalho? Um trabalhador-pesquisador ou um pesquisador-trabalhador cujo eixo das finalidades esteja afetado a tal ponto que sua paixão o movimente, que sua necessidade o leve a procurar. Procurar os meios, buscar novos caminhos, tudo ao contrário da confortável atitude copiosa e exaustiva de citar e citar linhas que não dão cor à impressão do objeto.

As monografias, dissertações e teses refletem essas relações ontológicas, próprias do pesquisador. E elas só podem produzir conhecimento se forem tratadas como trabalho. Caso elas se realizem a partir de finalidades imediatistas ou burocráticas, elas serão retalhos alinhavados da dispersão de já ditos.

Para que o eixo das finalidades do pesquisador seja afetado, para que ele seja desafiado em suas paixões, para que sua necessidade de procurar aumente, todas as suas certezas têm que cair, menos o desejo de produzir. Quem caminha no pro- 
cesso de pesquisa carregado de certezas perde o desejo. Neste caso, ou abandona a investigação e culpa o objeto de suas desculpas, ou entra na copiosa e frustrante missão de costurar citações.

Repetir o mesmo, ontologicamente, não é próprio da esfera social. O que o ser recebe desse convívio entre livros e teorias é matéria-prima para a obra, para o trabalho. Não é a obra. Porque os autores são fundamentais: mas são matéria-prima. Eles são o ponto de partida para o continuum a partir do qual o ser social, em seu estar-no-mundo, pode viver a condição ontológica de pôr o novo.

As produções universitárias são objetivações do mundo dos homens, ou seja, são trabalhos realizados, produto de uma teleologia, de finalidades que se dão através do cogito, da razão, do pensamento. E mais ainda: do desejo de produzir, de pôrde-si para a humanidade. Mas não tratamos aqui de posições teleológicas primárias (as voltadas à transformação da natureza), mas sim de posições teleológicas secundárias, aquelas que influenciam a consciência de outros homens, a fim de que realizem determinados atos, o trabalho intelectual.

Ou seja, as relações trabalhistas são mediadas na universidade pelo que ela produz como conhecimento. Entretanto, como ela concentra as suas atividades no ensino, está distorcendo os fundamentos do ser social em sua concepção ontológica, na medida em que, pelo ensino, se põe a repetir o mesmo através de "milhares de professores fazendo conferências para milhões de ouvintes passivos, que pouco ou nada vão aproveitar do que estão ouvindo" (Severino, 2007, p. 24-33).

Sem esquecer que a condição do novo é carregar consigo o legado, a partir do qual o pesquisador dá o salto ontológico, resta pensar o limite da necessária continuidade para que se dê a reprodução social, momento de transformação, através do avançar das produções universitárias. Aqui o conceito de 
reprodução não corresponde ao sentido biológico de repor o mesmo, nem ao sentido linguístico de repetir o já dito, mas à expressão da singularidade como resultado do salto para a produção do novo, uma atitude. A reprodução social não põe o mesmo. Diferentemente da biológica, ela põe o novo para o mundo.

Não estamos relacionando singularidade a singular como exemplar da humanidade, mas à marca do si-mesmodo-pesquisador na produção, algo que consegue ir para além dos já-produzidos, a despeito das barreiras sociais existentes. Precisamos esclarecer que não estamos considerando, então, o singular como um exemplar do mundo dos homens, mas, repetimos, o pôr-de-si para melhorar o mundo.

Diante dessas instâncias constitutivas do ser, três verbos são definidores: permanecer, repor e produzir. Ou um pesquisador faz permanecer a impressão de um objeto existente; ou ele repõe um objeto conhecido ou ele produz uma impressão nova de um objeto antes conhecido de outra forma ou mesmo desconhecido.

Nesse sentido levamos em conta o movimento desse constante devir outro. Cada produção, cada escrita na universidade não começa em si, nem se finaliza em si, mas traz no seu efeito-fim a próxima pesquisa. Cada produção é o momento limite entre a digestão de algo anterior, das leituras anteriores, de cujas sobras se nutriu e a possibilidade do que há de vir na condição de outro conhecimento. Isso justifica o que está dito neste livro: o salto para o novo se dá por um olhar a mais que se acrescenta ao precisamente-assim-existente.

Por exemplo: o que há de movimento na lógica especulativa hegeliana situa Hegel como base de continuidade tanto para Lukács quanto para Lacan. Ambos partiram também da filosofia hegeliana e deram o salto de suas elaborações associadas a outros. Lukács, da vertente hegeliana, entrou na corrente 
de Marx, criou a Ontologia do Ser Social; Lacan, na de Freud, avançou na Psicanálise para outro lugar: a Linguagem; Pêcheux, na corrente de Althusser e Lacan, construiu a teoria do discurso. É a continuidade da reprodução social dos saberes. O pesquisador, ao ler, não necessariamente repete uma teoria, mas a utiliza como lente conceitual para acentuar o poder de sua lupa e produzir um objeto que joga o conhecimento para outro lugar.

O motivo de retomar essas esferas está no fato de se poder pensar o valor ontológico da possibilidade de criação nas produções universitárias em função dessa relação continuidade/reprodução social. Encontramos aí a possibilidade de as produções universitárias surpreenderem a partir de tudo o que já foi dito; a possibilidade de uma produção que avance da subjetividade, aquilo que só diz respeito especificamente ao sujeito-pesquisador, para uma singularidade que também é resultante da porção de universalidade no pôr-de-si que, ali guardada, diz respeito à generalidade do mundo dos homens.

$\mathrm{O}$ que parece haver é, geralmente, quase uma mera reprodução linguística, porque o posto não é tomado como momento para que se dê a continuidade pelo salto para outra coisa como possibilidade de ruptura, para o momento de emancipação e de expressão do genérico, mas o posto é, na maioria das vezes, o lugar de chegada. Em vista disso, pensamos que o trabalho, abstraído em seus nexos causais internos, ajuda a localização do igual, do repetitivo e a possibilidade de realizar as diferenças. Por isso, também abstraímos sobre as produções universitárias como trabalho.

Diferentemente do que acontece na esfera biológica, para que o ser social abstraído do sujeito social produza conhecimento, ele requer mediações da fala, que, neste caso específico de pesquisa, objetiva-se nas produções universitárias. Este é outro conceito que esta ontologia nos possibilitou depreender dessas mesmas produções. 
Refazendo a articulação, o texto produzido na universidade guarda, em sua malha, o que é próprio do ser social que o escreve. Como neste momento o pesquisador já passa a ser visto sob a égide de um legado, começamos a denominá-lo de sujeito social ou de sujeito do discurso. E o acesso a esse legado se dá por uma questão de imanência para pôr algo de novo como salto na efetivação ontológica de sua condição de ser. Nessa malha, o pesquisador deveria encontrar sua identidade na mediação entre o que é seu - sua produção - e o que esta produção encarna do que passa a ser do gênero humano ao qual se aliena através dela.

O que há de importante na noção de continuidade quando o objeto são as produções universitárias é o fato de que essa noção também explica que o que se diz mantém, em parte, o que já foi dito. São essas construções teleológicas que conduzem a outras. Uma posição teleológica incorpora, necessariamente, as anteriores a ela que é suprassumida pelas posteriores, incorporada às anteriores. As construções teleológicas, os projetos dos pesquisadores, favorecem a reprodução dos indivíduos e da sociedade e difundem a singularidade (Lukács, 1981).

Nesse continuum, novos conteúdos podem ser articulados, trazendo o inédito. É a possibilidade de produzir e não apenas de representar o conhecimento, tal como acontece em grande parte das produções universitárias. Para isso, o que há de individual subjetivo articula o particular e o genérico até a elevação do gênero ao seu ser-para-si na dimensão da singularidade.

Tudo isso é possível porque foi superado o mutismo originário do homem, engastado que está nas malhas significantes através da qual vai balizando o que recebe da cultura e o que aliena de si à generalidade, entregando-lhe o novo e atingindo patamares cada vez mais articulados de sociabilidade. 
Com esse médium, a linguagem, a qual está na ontologia do ser social sob a denominação de fala, o homem baliza as suas relações e vai produzindo, nessa processualidade cumulativa, nexos internos que trazem a mudança e a transformação à totalidade social, cuja base se dá na singularidade que é a expressão do ser-indivíduo-humano.

Consideramos essas reflexões extremamente necessárias, porque, sem ir mais profundamente às abstrações que fundam quem produz na universidade, ficaríamos na análise superficial de sua aparência sem condições de buscar os indícios do que está sendo, naquilo que é, sem, entretanto, desconectar o ser de suas relações sociais concretas. E uma das metas do projeto ontológico de Lukács é "resgatar [...] o princípio de que a análise do ser deve preceder a análise do conhecer, já que este último é [...] a práxis social global" (Coutinho, 1996, p. 19).

\section{SER SOCIAL, LINGUAGEM, PESQUISADOR E PRODUÇÃO DO NOVO CONHECIMENTO}

A inquietação que ronda as investigações sobre as produções universitárias está na hipótese de que não são tão frequentes os momentos de ruptura, diga-se, de criação, a partir do legado ideológico recebido dos autores. Sabemos, entretanto, que é ontológico o fato de esse legado ter que ser levado em consideração, porque é a base da continuidade/ reprodução e sociabilidade/ individuação, e constatamos também que é ontológica a exigência de pôr o novo como salto para a esfera social. Aliás, sem a categoria do novo, não se dá a singularidade e tudo se configura na mera reafirmação do já existente.

Neste momento, separamos as produções universitárias como um exemplar da fala, abstraído da linguagem. Na ontologia é feita a diferença entre linguagem e fala. Esclarecemos que a linguagem, para Lukács (1981), é toda forma de comu- 
nicação, inclusive entre os animais; que a fala é a mediadora na realização dessa trama bem tecida da sociedade, através de atos concretos e criativos. Para ele, estão "os pretensos germes de linguagem [...] no reino animal", não havendo dúvida "de que entre os animais superiores ocorrem comunicações, até muito precisas" (Lukács, 1981, p. 188-189). Mas o fato é que, para a mesma ontologia, a fala é sustentação da continuidade.

Se a reprodução se dá no processo de individuação "subjetiva", que é constitutivo da singularidade, e se o novo é uma condição para que isso ocorra; se a possibilidade de materializar esse novo se dá através da "fala", neste caso as produções universitárias, manifestações da fala, acabam sendo a condição do novo. Caso contrário, só se dará a reafirmação do mesmo, a exemplo da linguagem dos sinais. Cabe à fala essa função de mediadora do processo de acumulação. A distância entre sujeito e objeto "é por ela potencializada" (Lessa, 1997, p. 180).

Mas a fala como condição do novo está em Benveniste (1988), de outro modo. Mesmo em Saussure (1998), que propôs uma Linguística da língua e não da fala, há a referência a esta como "ato individual", "heterogêneo".

Voltando ao conceito de Linguagem de onde se abstraiu a fala para pensar as produções universitárias, pensamos que devam ser guardadas as devidas reservas por ser um abuso de termos associar linguagem ao mundo animal, tendo em vista a pesquisa de Karl Von Frisch, professor de zoologia na Universidade de Munique, a respeito do processo de comunicação entre as abelhas.

O que causou curiosidade ao cientista foi o fato de uma colmeia inteira ir em busca de uma solução açucarada, depois

6 Aqui é o termo "subjetivo" que está entre aspas porque, durante esta pesquisa, não excluiremos um do outro, mas explicaremos teoricamente em que momento "o indivíduo é interpelado em sujeito" (Althusser. 1996). 
de ter sido encontrada por uma operária colhedora. Esta, tendo ali se alimentado, volta à colmeia, realiza uma dança que é o próprio ato da comunicação. São duas danças diferentes: uma se dá através de "círculos horizontais da direita para a esquerda, depois da esquerda para a direita"; a outra, "acompanhada por uma vibração contínua do abdômen" (Benveniste, 1988, p. 61), vai descrevendo a forma de oito. A primeira tentativa do cientista foi buscar sentido para aquelas danças. E pensou que uma, "a dança circular, anunciasse o néctar e a dança em oito, o pólen” (Benveniste, 1988, p. 61). Depois de alguns estudos, ficou constatado que as danças sinalizavam a distância do alimento.

Fica como reflexão, a partir dessa experiência, a relação entre "o conteúdo da mensagem [...] que se refere sempre e somente a um dado, o alimento", e o "contraste com o ilimitado dos conteúdos da linguagem humana" (Benveniste, 1988, p. 66). "Não há relação necessária entre referência objetiva e a forma linguística" (Benveniste, 1988, p.66). Talvez a paixão de alguns pesquisadores desta área da linguagem esteja na possibilidade de um novo, que é inerente à linguagem verbal, à fala, por ser própria de um ser que participa de um jogo linguístico na posição dialética de um jogador à procura de novos sentidos.

O que seria, então, se o ser não contasse com a novidade trazida pela linguagem no movimento da vida, que possibilita o novo, mesmo que inventado na teia do significante? A condição de ser-de-linguagem obriga o sujeito social - pesquisador - a ser diferente das abelhas: se a dança para elas não passa de dois movimentos que se repetem na direção do alimento, a fala, para ele, esboça o infindável de outros alimentos, não apenas os necessários, mas os desejados.

Há, neste caso particular de realização da fala nas produções universitárias, algo que pode ser inventivo, na pers- 
pectiva de escrita-trabalho ou escrita laborativa. Aqui, pensamos que nós, pesquisadores, perdemos de viver a novidade da produção de conhecimento, a nossa mais valiosa forma de entregarmos a nossa singularidade ao gênero humano. Estamos desperdiçando a possibilidade de surpreender, por causa da reprodução do mesmo.

Por mais que nos debrucemos para pensar a necessidade de um médium capaz de "conservar na consciência e tornar comunicável as aquisições do gênero humano: a fala” (Lukács, 1981, p. 193), jamais se esgotariam os engendramentos dessas peças linguísticas geniais que se articulam ao infinito das possibilidades linguísticas em favor das singularidades. O que “impossibilita pensar em 'linguagem' entre as abelhas” é a “'fixidez' do conteúdo, a invariabilidade da mensagem, a referência a uma única situação, a natureza indecomponível do enunciado, a sua transmissão unilateral" (Benveniste, 1988, p. 67).

Essa fixidez é o contrário do que deve acontecer com o ser social - o pesquisador - que utiliza a mediação da fala cuja condição de ser-de-linguagem está na possibilidade de jogar com elementos que se combinam e se recombinam através de leis internas e que se desdobram em enunciados cujos locutores não podem ser simplificados, mas desdobrados em enunciadores que ele organiza. E esses sentidos são decorrentes do processo teleológico cuja palavra "sempre exprime a generalidade do objeto, o gênero, a espécie, não o exemplar singular" (Lukács, 1981, p. 193).

Isso nos leva a perceber que as produções incorporam um espaço de desdobramento de tendências que operam no seu desenvolvimento; ou o impulso de fixar o individual único subjetivo, que encarna finalidades que só dizem respeito ao pesquisador; ou a tentativa de eliminar, através de definições, de repetições, a ambivalência no sentido das palavras, a fim de fixar as determinações mais gerais, universais, estas últi- 
mas que favorecem a fuga do pesquisador de seu processo de produção, ou ainda a consequência de um sistema de ensino que se funda num processo de informação e se reflete na reposição dessas informações nas monografias de conclusão de curso, por exemplo.

A singularidade não está nem na subjetividade, nem na generalidade e muito menos na repetição, mas naquilo que a subjetividade possa suprassumir da generalidade humana para devolver-lhe no singular algo que garanta o movimento da reprodução social.

Pensando nas produções universitárias, observamos que elas incorporam as contraditórias tendências que operam no processo de sociabilização e na interioridade da categoria trabalho. Dele deriva toda a tensão inexaurível dessa síntese entre o individual e o genérico para a possibilidade de ser singular ou a exaustiva repetição do mesmo. Além de serem portadoras da relação viva entre os homens, encarnam a processualidade da teleologia essencial à objetivação que, neste caso específico, finaliza por constituir-se como o próprio objetivado.

A fala nasce da sociabilidade a partir de impulso, conteúdo e forma. E, na legalidade interna à fala, o gênero humano "produz as alegrias e as dores, as ações e as catástrofes da humanidade" (Lukács, 1981, p. 201). Pela linguagem, o ser vive num movimento incessante de acumulação e transformação e é, pela fala, que o sujeito social ou o sujeito do discurso vive o seu dilema entre o dizer e o silenciar; o pensar e o não dizer, construindo o objeto pelo conhecimento que o produz e não pela representação que o reduz, como consequência de suas escolhas face a tantas alternativas. 
DISCURSO, IDEOLOGIA E INCONSCIENTE: INTERFERÊNCIAS NA PRODUÇÃO

O discurso é o lugar onde a fala expressa a particularidade de um sujeito que "divide o espaço discursivo com o outro", o que sugere "a relação de um sistema significante com sua exterioridade" (Orlandi, 1994, p. 53-54). Da ontologia para a linguística, do mundo para a vida, a sociedade, a história, os contextos e as condições de produção, percebemos que existem questões genéricas que colocam a produção escrita como dilema em qualquer circunstância, sabendo que o sujeito social não representa mais a autonomia de quem diz, mas a "subjetividade [...] relativizada no par Eu-Tu, incorporando o Outro como constitutivo do sujeito" (Brandão, 2006, p. 50).

A escrita na universidade se particulariza, então, por ser este um universo ora propício à produção de conhecimento, ora distorcido pela representação do objeto. A regularidade dessas produções reflete o que há em cada um desse particular definidor das condições de produção que nelas se manifestam.

E o discurso é a expressão da particularidade - o grupo e suas especificidades - intermediador entre a individualidade subjetiva e a generalidade universal, marcado pela ideologia que “é 'uma representação' da relação imaginária dos indivíduos com suas condições reais de existência" (Althusser, 1996, p. 126). Essa carga ideológica "é eterna, exatamente como o inconsciente" (Althusser, 1996, p. 125), e obriga a fazer escolhas que o sujeito pensa ser dele. Nesse sentido, a transparência da linguagem é ideológica; a neutralidade científica é ideológica, assim como é ideologia toda lição que permite correr fervorosamente em busca de um objetivo desejado, no esquecimento de precisar atingi-lo.

"A ideologia interpela os indivíduos em sujeitos". Interpelar, no sentido mesmo de recrutar. E o faz de tal forma que ela 
acaba se negando a si pela voz do indivíduo que interpelou como sujeito. Ou seja, é ideológica "a negação do caráter ideológico da ideologia". Isso implica "a 'existência' de um Outro Sujeito, Único e Central", em cujo nome "todos os indivíduos" são interpelados "como sujeitos". Essa interpelação é "duplamente especular", porque também "garante seu funcionamento". Interpelado, o sujeito se reconhece na particularidade; tem garantia de fazer parte dela; trabalha como bom-sujeito pela ideologia, reconhecendo que as coisas são realmente assim e não de outro modo (Althusser, 1996, p. 133-138).

Relacionamos essa teoria sociológica ao contexto deste livro, considerando a universidade como um espaço particular que determina o que deve ser feito pelas condições postas no ambiente acadêmico, o qual, em consequência, cobra atitudes de bons-sujeitos. De um lado, estão alunos prontos para reproduzirem os conteúdos recebidos em milhares de conferências próprias do sistema de ensino, onde o que conta é a informação de conhecimentos para serem reproduzidos; de outro, pesquisadores plenamente identificados com os interesses do programa de pós-graduação ou do orientador ou do grupo de pesquisa.

Referimo-nos a uma interpelação imediatista, a qual gera uma escolha oportuna. Isso é ideológico, porque acontece de forma regular como marca da particularidade contextualizada. E isso está ocorrendo, mesmo que seja extremamente comprometedor para o desdobramento da pesquisa. Exemplificamos aqui com o interesse pela qualificação, o qual se torna ideológico - e, portanto, discursivo, próprio da universidade, cujo interesse pela pesquisa se constitui de discursos de outras ordens.

$\mathrm{E}$, nas produções universitárias, as necessidades materiais postas por particularidades discursivas ou particulares eliminam também o desejo e impedem que o texto flua como sublimação da falta para a produção de conhecimento. 
O que é próprio da voz de um pesquisador, de seu discurso, é aquilo que a ideologia o interpela a fazer não como desejo, mas como necessidade: ser graduado e, em seguida, ser especialista, mestre ou doutor. E a universidade é o lugar para encenar esse fazer. "Os lugares pré-interpretam" (Lacan, 1992, p. 9). E a grande angústia do pesquisador é este sujeito único e absoluto, por exemplo, uma teoria, em volta da qual a pesquisa tem que fluir ou este sujeito único e absoluto - o mercado, em torno do qual os sujeitos têm que ser qualificados como pesquisadores, mesmo sendo consequência de um processo de informação vivido na condição de aluno.

Nessas produções, o "[...] recalque inconsciente e o assujeitamento ideológico estão materialmente ligados” (Pêcheux, 1997, p. 134) e levados em consideração porque essas produções estão sendo delineadas como espaços discursivos, espelho de sua particularidade: a universidade. Nesse sentido, elas são lidas a partir dos elementos constitutivos do discurso em seus princípios fundamentais: a ideologia e o inconsciente. Sob essa lente, a subjetividade também é "o efeito da 'exterioridade’ do real-ideológico-discursivo” (Pêcheux, 1997, p. 172).

PRODUÇÕES UNIVERSITÁRIAS E TRABALHO: A IDEIA DE MÁQUINA ENUNCIATIVA

Tratamos das produções universitárias como trabalho, suspendendo-as como um exemplar de linguagem sob o enfoque linguístico-econômico, no contexto mercadológico, sabendo que estão na relação valor de uso e valor de troca, com base na teoria marxiana.

Nesse contexto, há "um capital linguístico total por meio do qual se dá a comunicação", que é "produção e circulação de mensagens no âmbito de uma comunidade linguística", as quais podem "esgotar-se no ato da recepção". As produções 
universitárias estão aqui colocadas numa perspectiva de "consumo ou fruição linguísticos" (Rossi-Landi, 1985, p. 83).

Levamos em consideração as "palavras, expressões e mensagens" como uma "espécie de mercadoria" que circula tanto quanto qualquer outro produto de consumo, "numa espécie de imenso mercado", uma comunidade linguística, onde também há "as regularidades que regem a circulação" e "os valores segundo os quais são consumidas e trocadas" (Rossi-Landi, 1985 , p. 85). Esse âmbito leva a uma grave "dessimbolização" (Dufour, 2005, p. 196) das produções universitárias que, escritas em série, são produtos de consumo. Grave, porque a singularidade é resultado das necessidades que movem a pesquisa.

Assim como as peças existem em função dos utensílios, as palavras existem em função dos enunciados. Fica estabelecida uma relação entre produção material e produção linguística e o enunciado, as produções universitárias, consideradas utensílio. Ora, a passagem de utensílio a máquina resulta em um desdobramento sob cujo olhar podemos considerar a possibilidade de existirem máquinas enunciadoras.

Quem produz na universidade é o pesquisador. Suas produções são resultado da condição do ser social que produz heterogeneidade. Se o contexto é mercadológico e se a produção é em série, por necessidades postas e não desejadas, está comprometido o caráter unitário do ser, a singularidade do pesquisador. A heterogeneidade inerente ao ser social se funda na categoria necessidade que vai surgindo com um contorno de acaso. E se essa necessidade passa a ser a mesma preponderante para todos, as produções universitárias estarão comprometidas pela reprodução do conhecimento.

Cada monografia, cada dissertação e cada tese é produzida a partir de condições de produção que determinam as finalidades ou necessidades do pesquisador. Se a universidade tem urgência de qualificar em série e se o pesquisador muitas vezes 
se vê no processo de qualificação determinado pelas contingências que o deixam sem escolha, o que poderá ser cobrado de suas finalidades?

PRODUÇÃO E SINGULARIDADE: A EXPRESSÃO DO UNO

Pensando sobre as produções universitárias, abstraímos delas quem as produz, o pesquisador, indo às questões ontológicas sobre o ser social, cuja condição de estar-no-mundo é o trabalho como possibilidade de pôr o novo, momento singular da reprodução social que sempre avança do continuum. Depreendemos também dessas produções a linguagem tratada sob a categoria de fala na ontologia e colocada também pela linguística como condição material do novo, do heterogêneo. Abstraímos do ser social, que se move através da linguagem, o sujeito social pelo discurso, cujo conceito foi possível chegar à exterioridade, lá onde se funda o ser pelo trabalho, conceito através do qual se dá a reprodução social por meio da produção do conhecimento no espaço da particularidade discursiva, a universidade.

Extraímos também dessas produções universitárias o que é materialidade linguística, o texto em si, diferente do seu discurso que é a historicidade que não está no produto, mas no processo. Eis que surgem da relação entre produto e processo conceitos importantes como os de subjetividade e singularidade.

Se, no item anterior, levamos em conta um sujeito iludido em sua autonomia, vemos a que ponto chega a dificuldade de ser uno na diversidade constitutiva do sujeito social, mas descobrimos que, apesar de todo o legado de interferências discursivas, a condição ontológica move o ser para expressar o uno e isso se dá através de pôr o novo, próprio da esfera social, assegurada por um objeto sempre à espera de um outro olhar para a transformação do mundo. 
Inferimos também que, se o novo é condição do ser e se esse ser tem que participar da reprodução social, o novo é condição do sujeito social e da singularidade e não está nas instâncias da subjetividade, que só diz respeito à individualidade, porque, para cumprir seu estar-no-mundo, o em-si avança ao para-si e daí até o em-si-para-si-do-gênero-humano.

A singularidade é então condição para a produção do conhecimento. Sem singularidade que avance do continuum para, através da teleologia e da ideação, participar da reprodução social, há a reposição do já conhecido e a ciência não vivencia o devir, porque se limita a representar conhecimentos.

O convívio do sujeito na dimensão da particularidade faz dele um sujeito social pelo discurso que aí o atravessa e o torna um sujeito social, produzido pelas relações socioideológicas, fato que nega a possibilidade de esse sujeito ser fonte ou origem de suas produções. Ainda nessa dimensão, o sujeito do discurso se encontra coagido a produzir o mesmo da particularidade das formações discursivas.

Se ele não consegue se debater para produzir o novo, ele cairá nas malhas do discurso próprio, no caso das produções universitárias, e poderá não realizar sua condição ontológica de estar no mundo. Se ele se debate através de teleologias que tomam como ponto de partida o pré-construído para alimentar um outro lugar ainda não explorado, ele poderá viver a singularidade como exemplar do universal humano, entregando sua parcela de contribuição à reprodução social para o movimento da generalidade do mundo dos homens.

Diante disso, a singularidade é um pôr-de-si a um tempo individual, subjetivo, particular com vistas a um patamar de emancipação para a universalidade do gênero humano, incorporado por um impulso superior de criar um outro caminho na produção de um outro conhecimento que entrega à generalidade. Para isso, não é suficiente um estilo. 
Para ser singular, não basta expor nas produções universitárias um modo de dizer especial. Este modo de dizer especial está aprisionado pelo linguístico, determinado por trejeitos materiais linguísticos. Não. A singularidade tem origem na teleologia e na prévia-ideação. Ela vem e está determinada pelas escolhas entre alternativas, pelas negações de outras alternativas, pela construção de finalidades, pela escolha de alguns conceitos em detrimento de outros. A singularidade é o processo de produção e, no produto, é quase impossível localizá-la. O resultado pode ser a negação da singularidade desde que, na origem do trabalho, esta tenha sido impossibilitada por escolhas apenas necessárias e não desejadas.

Só pelo desejo é possível também gerar o novo que nasce da falta que impulsiona o pesquisador a produzir para tamponá-la. Mas os atos do ser social não são apenas teleológicos, mas atos teleológicos postos, objetivados a partir de determinações não abstratas, mas abstraídas das relações concretas. Disso decorre que a finalidade é o pôr teleológico concretamente. Por isso, são as produções universitárias abstraídas como trabalho, o que nos permitiu pensá-las a partir dos nexos internos a essa categoria.

Os nexos internos ao trabalho vão articular aquilo que é constitutivo da singularidade: a subjetividade que se eleva ao patamar de individualidade autêntica até a universalidade elevada, por sua vez, à categoria de generalidade humana, pelas relações sociais de trabalho primário ou secundário. E os nexos internos à produção é o caminho que abstraímos para que o pesquisador possa pensar a possibilidade de pôr algo de novo, através da teleologia, ou seja, de todo o processo de produção, inclusive o que é anterior à objetivação do produto, o conhecimento novo, não necessariamente as produções.

O fundamento da singularidade está na escolha da pesquisa a ser realizada na universidade, na construção de um 
projeto sempre vinculado à necessidade que não pode ser nem estritamente subjetiva, nem discursiva, nem radicalmente generalizada pelo científico, mas tecida de tal forma que seja do interesse do gênero humano para a reprodução social.

Isso porque o processo de trabalho tem origem na teleologia e na prévia-ideação. É nesse processo que "o homem entra em relação dialética pelos nexos causais com o mundo real, com as determinadas relações objetivas" (Saboia, 2001, p. 82). $\mathrm{E}$ a realidade é alterada, gerando "consequências e resultados imprevistos que resultam em novas necessidades, assim como em novas possibilidades para atender a essas necessidades" (Saboia, 2001, p. 82).

Essas concepções se desdobram no dilema do discurso neutro e no fato de as produções universitárias exigirem do pesquisador uma natureza de ciência diferente da ciência normal, porque esta fere o que de ontológico torna-se condição da pesquisa com marcas do individual singular, próprias aos nexos internos a qualquer trabalho. E isso não se dá no nível da mera reprodutibilidade do objeto, nem do legado já apropriado, mas na dimensão do objeto que não se mostra em absoluto, a não ser no movimento dos diversos olhares que o produzem.

Tratamos a partir daí de desdobramentos do caráter dual na relação do pesquisador com a realidade. Precisamos esclarecer que esse caráter dual está na tensão interna entre o que é individual, subjetivo, particular e a universalidade genérica. As produções universitárias, como tendem à abstração generalizadora da ciência, acabam se desequilibrando entre o que precisa ser científico no discurso daquela particularidade e o que, ontologicamente, é subjetividade individual determinante da necessidade que se desdobra em finalidade como escolha entre alternativas para atingir a singularidade. Ou seja, nessas produções, esse sujeito atravessado por ideologias vive o esforço de ser único, mesmo que a pluralidade o constitua. Elas 
acontecem na interna tensão entre nexos individuais, subjetivos e genéricos.

As finalidades, a princípio particulares, vão sugerindo abstrações cada vez mais genéricas a ponto de suprassumir, na síntese, questões inerentes ao gênero humano, a tal ponto pertinentes, que acabam pondo o novo como consequência da ruptura com o legado recebido.

Entretanto, a imediaticidade das relações sociais, num contexto de dessimbolização, está tornando imediatistas as finalidades das produções universitárias e o resultado é o estranhamento: o pesquisador não se reconhece no que produz. Ele tem sido, em parte, reprodutor do mesmo, tal como se dá numa esfera anterior ao salto pelo qual se elevaria ao patamar hominizador de ser social. Para Lukács (1981, p. 39), “com o que a consciência [...] reflete, a realidade adquire algum nível de possibilidade", sem a submissão da subjetividade ao objeto.

Dessa forma, as produções universitárias incorporam e materializam, também em um caráter dual, o que foi posto pelas alternativas, sendo resultado de uma possibilidade entre tantas outras e de necessidades e finalidades postas, guardando as que ficaram como potencialidades para desdobramentos de outras objetivações. É a alternativa que movimenta o reflexo e pode gerar conhecimento. Isso não se reduz a "um único ato de decisão", mas a "um processo, de uma ininterrupta cadeia temporal de alternativas sempre novas" (Lukács, 1981, p. 43). Não se reduz, simplesmente, "à execução mecânica de uma finalidade" (Lukács, 1981, p. 44).

O fato é que, pelo critério ontológico, a objetivação, ou seja, a realização de um trabalho - uma monografia, uma dissertação, uma tese - promove o retorno do universal sobre o singular. A isso Lukács denomina alienação. Quando o pesquisador produz conhecimento para entregar à generalidade, ele terá suprassumido a generalidade humana que há nele. $\mathrm{O}$ 
contrário é o estranhamento: "uma ação de retorno da esfera objetivada sobre a individuação" (Lessa, 1997, p. 114). O primeiro é o que justifica o ser-precisamente-assim existente; o segundo, nega-o. O primeiro é entrega de si; o segundo é negação dessa entrega, atitude de egoísmo.

Enquanto a alienação resulta na individuação e na sociabilidade em patamares crescentes de generalidade, o estranhamento resulta num empecilho socialmente posto à plena explicitação da generalidade humana, na esfera social, por causa da reposição do mesmo. Já a alienação, para Lukács, se dá quando o trabalho atinge seu momento universal de emancipação. Nesse sentido, liberdade e trabalho estão condicionados um ao outro.

O devir humano dos homens é base da singularidade e a bipolaridade entre o que é particular e universal exige que o sujeito do discurso tome consciência de sua responsabilidade, ao passo que nele se fundam valores cada vez mais genéricos. Esse salto acontece entre o utilitário e a valoração. A utilidade está no âmbito da imediaticidade e só a valoração, que está para além da utilidade imediata, pode elevar as reflexões teleológicas a níveis superiores.

Em função disso, pensamos que há um momento onde é identificado o salto entre o que é subjetividade do pesquisador e o que é interesse das produções universitárias como particularidade de uma formação que se expande à generalidade pelo singular.

Numa certa medida, a produção do conhecimento, através da qual o pesquisador gera a reprodução social e se aliena na direção da generalidade humana, possibilita pensar também que "não é concebível nenhuma relação que gere a alienação a não ser a do significante" (Lacan, 1998a, p. 854). O que se aliena é o processo desse gozo e nunca o objeto, num processo que é significante por representar o sujeito para outro significante. Essa tensão entre o eu e o tu obriga a "definir 
as formas de conjunção-disjunção da relação do sujeito com o Outro" (Kaufmann, 1996, p. 20).

Essa tensão é constitutiva de um sujeito que se diz consciente, livre e, na maioria das vezes, acredita que tudo pode ser por ele deliberado, mas é constituído pela lei do Outro, "lugar em que se situa a cadeia do significante que comanda tudo que vai poder presentificar-se do sujeito, é o campo desse vivo onde o sujeito tem que aparecer" (Lacan, 1998b, p. 194).

É neste ponto que consideramos a pesquisa, esse processo de hiância do sujeito-pesquisador, que transforma o processo num incessante encontrar de uma sombra que ele insiste em traduzir. Porque percebemos que esse processo de hiância é circular entre o sujeito e o Outro. "Do sujeito chamado ao Outro, ao sujeito pelo que ele viu a si mesmo aparecer no campo do outro, do Outro que lá retorna" (Lacan, 1998b, p. 196). Penso que nenhuma garantia científica que os pesquisadores tenham recebido do legado cultural elimina o conflito de fazer aparecer o uno, singular, diante de tantos atravessamentos sociais. O autor-citado nessas produções é um deles, através do qual o pesquisador geralmente repõe o mesmo.

Entramos em camadas mais profundas de reflexão, porque sabemos que muitas vezes o finalizar de uma produção universitária converte-se no desejo de não mais tocá-la, tal é o estranhamento do pesquisador. Ele não se reconhece, não se vê no que reproduziu, porque, por ter apenas reproduzido, vê-se sufocado pela manada.

\section{PRODUÇÕES UNIVERSITÁRIAS COMO RESULTADO DE UMA PESQUISA PLENA DE SENTIDO}

Para que uma produção universitária objetive uma pesquisa plena de sentido, cumpre que ela veicule esse processo àquilo que é o fim, a priori, de todo trabalho: a alienação. A 
entrega de sua parte à humanidade. Através dessa produção, o pesquisador fará a síntese entre o que é particular, para, a partir de uma abstração cada vez mais larga, galgar espaços de generalidade, como justificativa primeira de todo o processo teleológico interno à processualidade da reprodução social, naquilo que também não depende só da consciência. “Todo ato de trabalho singular é portador de elevar sua singularidade imediata à componente da generalidade humana" (Lessa, 1997, p. 140).

Esse salto ao que não tem limite - a condição humana - nos permite pensar a liberdade através de uma pesquisa emancipadora, plena de sentido. E aí as palavras expressam ou um olhar imediatista que se desloca para outros espaços ou um olhar gerado por nexos causais de uma teleologia e de uma ideação favoráveis à produção de conhecimento. Isso implica o confronto do pesquisador com o objeto, sabendo que ali há um momento de criação, de produção.

Dessa produção de conhecimento "nasce uma nova forma de objetividade, mas não uma realidade - em sentido ontológico estrito" (Lukács, 1981, p. 38). O objeto recortado da realidade resulta de uma construção inventiva, em função de que a invenção se dá pelas determinações que não pertencem apenas ao objeto, mas da relação entre sujeito e objeto que não é de identidade e nem de fiel fotografia. Esse fato fica comprometido por um sistema constituído prioritariamente da relação "ensino-aprendizagem", criando um contexto que favorece a representação de algo aprendido, impossibilitando que esse processo de invenção científica possibilite a reprodução social.

E mais: se nasce uma nova objetividade, o objetivado é sempre uma outra coisa que não aquela, a princípio, refletida. É a reprodução social. Por maior que seja o rigor da pesquisa, jamais quem a realiza poderá chegar a resultados exatos, porque, mesmo o olhar extremamente rigoroso, só conseguirá 
capturar aquele lado que se redefiniu pela necessidade que possibilitou pôr as finalidades e trabalhar sobre as alternativas. $\mathrm{E}$ as produções universitárias vão incorporar não o legado, mas o que sobra dele no decorrer da teleologia que o recria no processo de sua construção.

A reflexão sobre o objeto vai produzindo-o e não reproduzindo-o, porque "as categorias pensadas compõem uma 'realidade’ própria da consciência”, é "uma 'nova forma de objetividade, mas não é uma 'realidade” (Lukács, 1981, p. 41). Pela ontologia, a reprodução não é "da mesma natureza daquilo que ela reproduz, tanto menos idêntica a ela" (Lukács, 1981, p. 41). Se as produções universitárias representam o objeto, a singularidade não lhe é constitutiva, porque, pelo que é possível inferir, é nessa outra objetividade produzida que está a singularidade e a produção do conhecimento. Qualquer tentativa de reproduzir pelo viés do idêntico está no âmbito da tradução e, inevitavelmente, da repetição. Na perspectiva do ensino parece ser esse o pacto.

Nas produções universitárias está o que o pesquisador recebeu do legado e o que, pela articulação dos saberes recebidos, possibilita-lhe dar o salto para outra coisa que não a mesma e cumprir o que lhe é exigido na reprodução social e na continuidade. Também a liberdade é condição da singularidade porque "todo setor singular do ser social tornado relativamente autônomo produz uma forma própria de liberdade" (Lukács, 1981, p. 156-157).

Uma pesquisa cheia de sentido exercita a alienação, a entrega de sua parcela de contribuição à reprodução social, como momento em que o homem não vê apenas o ponto de vista de suas necessidades materiais, pessoais, individuais, mas o ângulo da condição humana inevitavelmente incorporada. É nesse instante que o pesquisador faz ou não a síntese para uma pesquisa cheia de sentido, pela possibilidade de produzir conhecimento ou de apenas representá-lo. 


\section{Por que produzimos na Universidade?}


Como as finalidades do pesquisador são determinantes da escrita que ele empreende, seja nas monografias, dissertações ou teses, colocamo-nos à escuta de suas falas, de seus interesses, de seus projetos, de seus projetos de vida, para ver onde ele posiciona sua pesquisa, quais os para-quês de sua investigação, o que pode movê-lo no processo, o que se pode esperar de produção ou de reprodução, dependendo das circunstâncias que circundam sua qualificação.

EPISÓDIO DE PESQUISA (I): CONVERSA COM UM GRUPO DE GRADUANDOS

Conversamos, primeiramente, com um grupo de graduandos sobre o processo de escrita na universidade, sobre o que produzem no momento de conclusão de curso: a monografia. Isso aconteceu numa situação de sala de aula da disciplina Prática de Ensino em Língua Portuguesa, com a presença da professora responsável por ministrá-la. 
Transcrevemos, então, a seguir, a conversa que se tornou um evento de pesquisa extremamente informal. Daremos realce ao que nos pareceu mais regular no que disseram. Para o pesquisador, utilizaremos P; para os informantes, I(1), I(2), I(3), I(4), I(5), I(6) e I(7). Em função de ter sido uma conversa coletiva, realçamos a regularidade que há na fala deles para fazer algumas inferências.

Fazendo uma "dedução frequencial" (Pêcheux, 1990a, p. 63), agrupamos as regularidades e fizemos as inferências a partir do conceito de necessidade do pesquisador sinalizada pelas categorias temáticas - pesquisador, autor-citado, objeto - para situar essa relação ou na atitude de representação ou de produção de conhecimento.

Pelas regularidades, a problemática do autor-citado como categoria temática foi a mais marcada. O objeto só foi tratado uma vez pela denominação de tema e o pesquisador se manifestou à procura de seu lugar, do pôr-de-si, através de palavras como originalidade, opinião, concordância e conciliação. Eis a entrevista:

\section{A ENTREVISTA 1}

P - QUAIS AS DIFICULDADES QUE VOCÊS ENCONTRAM NA ESCRITA AQUI NA UNIVERSIDADE? I(1) - Para mim, principalmente no início do Curso, era o tipo de texto. O professor pedia para se escrever uma resenha e eu não sabia o que fazer na resenha. Saber o que o professor quer que se escreva... I(2) - Na monografia, a minha dificuldade está no autor... não ter opinião para colocar no texto porque tem que colocar muitos autores. 
P - O QUE É UM TRABALHO MONOGRÁFICO?

I(1) - Desespero. Escolher um tema e a dificuldade de falar de um autor que fale daquele tema.

I(2) - Ver como fazer alguma coisa original.

I(3) - Como conciliar a ideia própria e a ideia do autor.

I(4) - Onde encontrar autores que concordem com o que a gente pensa?

I(5) - Como lidar com o autor? Buscar confirmação? I(6) - Eu não sei se eu concordo com o autor ou se o autor concorda comigo.

P - COMO VOCÊS PENSAM EM FAZER CITAÇÕES?

I(1) - Em frases, passagens do texto dele. Em algum fragmento ligado ao tema.

I(2) - Não encontrei autores que usam o teatro na língua estrangeira.

I(3) - Ela precisa encontrar um autor que relacione teatro e ensino (reafirmando I2).

I(4) - Ela precisa procurar um professor que aplique o teatro ao ensino (reafirmando I2).

I(5) - Ela precisa procurar a vivência de outros.

I(6) - O ponto central é a questão da gente procurar o autor para o ponto de partida.

I(7) - A primeira coisa que a minha orientadora me perguntou: - Você já encontrou o autor que fala sobre o tema? Eu acredito nesse tema por isso vou lhe ajudar.

\section{DESCRIÇÃO DA ENTREVISTA}

Dos 7 graduandos entrevistados, quase todos estavam mais ansiosos por terem que encontrar autores para citar e poucos esboçaram alguma ansiedade com relação ao objeto. 
Inferimos que a necessidade do pesquisador não está na dimensão de um processo investigativo que possibilite construir um objeto, porque, na regularidade das falas, os olhares não estão dirigidos a essa possibilidade, o que sinaliza para um sistema onde o ensino é transmissivo.

Em decorrência, a ilusão é a de que tudo está pronto, o mundo está dado e, se tudo já foi produzido pelos autores, a necessidade é de um autor porque, como está na voz da particularidade universitária, a dificuldade está no autor.../ porque "tem que colocar muitos autores/ um autor que fale daquele tema”. E o pesquisador precisa "da ideia do autor, e sua pergunta é onde encontrar autores/ como lidar com o autor/ como usar passagens do texto dele,/ ou algum fragmento ligado ao tema”.

Em 15 manifestações dos informantes, 10 expressaram a preocupação com o autor. Poucos se referiram ao objeto, confundindo-o com a ideia de tema.

Gostaríamos de chamar atenção para o fato de não encontrarmos, neste nível de necessidade de autor, a repercussão do dilema da voz do outro na própria ou algo que nos permitisse levar em conta certa consciência do pesquisador sobre a heterogeneidade discursiva, ou as várias vozes que atravessam o sujeito do discurso, os vários enunciadores constitutivos da voz do locutor. Ou seja, a necessidade de autor não é uma decorrência da noção de "alteridade", da "dualidade do sujeito", do "sujeito descentrado", do autor como "espelho" para a função do eu do pesquisador (Lacan, 1992). O discurso que aí se constrói pelas regularidades é distorção de alteridade, de dualidade do sujeito e de sujeito descentrado. A voz, nesse sentido, está atravessada, sim, por um discurso constituído de uma necessidade de autor como ponto de partida, uma transposição de responsabilidade e uma certa frustração por causa 
da ausência quase obrigatória de si na produção. Talvez pela interferência de uma polifonia distorcida que se dirige ao conhecimento pronto para reapresentá-lo.

Percebemos mais uma vez vestígios dessa consequência de um "ensino transmissivo" que não constrói o processo investigativo, mas repassa conhecimentos já-produzidos por autores que não são levados em conta a partir da necessidade de um pensamento conceitual próprio das "teleologias secundárias" constitutivas do trabalho intelectual, que não é uma forma derivada do trabalho primário, mas uma complexificação deste.

O processo de produção exige do pesquisador articulações, cruzamentos teóricos, relação de conceitos, mas a particularidade universitária precisa "encontrar um autor que relacione $\mathrm{x}$ e $\mathrm{Y} /$ precisa procurar um professor que aplique $\mathrm{x} \mathrm{a} \mathrm{Y} /$ ”. Nela, o pesquisador precisa "procurar a vivência de outros/" mas o ponto central é a questão de "procurar o autor para o ponto de partida e, talvez, de chegada".

Nesse discurso, a pergunta - "você já encontrou o autor que fala sobre o tema?" - tira a possibilidade de construção do objeto para a "produção do conhecimento" e, na "representação", elimina o "reflexo", o "impulso", a "pulsão", instala a "neutralidade" pelo preenchimento da falta que ausenta a paixão e angustia, não pelo embate produtivo do pesquisador com o reflexo, mas por uma procura incessante do conhecimento pronto que está escondido em algum lugar e pela necessidade negada de pôr o novo como desejo de alienação e nunca de estranhamento.

Na produção de conhecimento, a angústia é produtiva, ela movimenta o desejo. Na representação, a angústia é frustrante porque afeta o movimento no sentido da reprodução e instala a imobilidade social. E o que frustra, na particularidade das produções universitárias, é o sentimento de "não ter opinião / não saber como fazer alguma coisa original/ é ter que conciliar 
a ideia própria e a ideia do autor/ é não saber como lidar com o autor". E essa angústia é desespero de encontrar autores que concordem com o que o pesquisador pensa/ porque "é difícil conciliar a ideia própria e a ideia do autor", porque o pesquisador "tem que buscar confirmação" e fica sem saber "se concorda com o autor ou se o autor concorda com ele".

O locutor não chega a se responsabilizar pela produção porque não se sente autorizado a isso e transfere a possibilidade de produzir conhecimento para a de representá-lo aos moldes de um sistema de ensino transmissivo, onde, ontologicamente, a ideia de conhecimento produzido bloqueia a emancipação, fundamental à reprodução social condicionada pela produção de conhecimento.

$\mathrm{O}$ que assume um lugar privilegiado no ensino transmissivo é o conhecimento já-produzido. Aí se dá a centralidade do autor-citado, o apagamento do objeto e a banalização do pesquisador passivo no processo de reapresentação do produto, resultante de uma escrita normal. A gravidade do apagamento está no fato de a relevância social da pesquisa se localizar no objeto, não no pesquisador em si, nem num autor. No momento em que o pesquisador dá prioridade ao autor, o objeto que é o centro perde seu lugar e isso provoca a repetição.

As abstrações feitas até aqui depreendem das produções universitárias o conceito de trabalho aqui especificado como trabalho de pesquisa que se objetiva numa escrita onde o novo é manifestação do ser social, o pesquisador. No contexto dessas produções, o novo conhecimento, através de uma nova impressão do objeto, é fruto da manifestação da singularidade para a reprodução social onde a subjetividade é o momento fundante do processo.

Apesar de, ao nos referirmos a pesquisador, estarmos tratando tanto do aluno quanto do professor, temos percebido que tanto um quanto outro são consequência de "escolas su- 
periores totalmente desequipadas das condições necessárias ao desenvolvimento de uma prática de pesquisa”, [...] as quais "se limitam a repassar informações fragmentadas" (Severino, 2007, p.29). E essa consequência constrange o movimento da produção de conhecimento e está somada à "política educacional desenvolvida no país" que leva a "lidar com o conhecimento sem construí-lo efetivamente” (Severino, 2007, p. 30).

Se o que funda o processo de produção do conhecimento pela construção de um objeto é a subjetividade, as necessidades determinantes de uma produção universitária deveriam estar na consequência da finalidade, a princípio subjetiva, até atingir pontos de genericidade de um conhecimento para além da "mera capacitação para repetir os gestos do taylorismo clássico” (Severino, 2007, p. 29).

EPISÓDIO DE PESQUISA (II): CONVERSA COM PÓSGRADUANDOS

Durante a pesquisa, perguntamos a graduandos e pós-graduandos sobre as maiores dificuldades que enfrentam no processo de escrita. Para este momento, selecionamos apenas algumas respostas que colhemos dos pós-graduandos em fase de mestrado e doutorado, durante a apresentação desta pesquisa em instituições públicas e privadas. Tendo em vista já termos analisado uma conversa com um grupo de graduandos sobre essas dificuldades, apresentamos a seguir a entrevista com pós-graduandos.

\section{A ENTREVISTA 2}

P. QUAL A MAIOR DIFICULDADE QUE VOCÊ ENFRENTA NAS SUAS PRODUÇÕES UNIVERSITÁRIAS?

$\mathrm{I}(1) \mathrm{O}$ direcionamento quanto aos autores que tratam do assunto. 
I(2) A normatização.

I(3) Formular meu texto sem interferência de autores.

I(4) Não ter leitura suficiente, ou seja, fundamentação teórica para tal.

I(5) O gênero: projeto/artigo científico.

I(6) Abstrair a partir do referencial teórico para justificar o meu texto.

I(7) Separar minhas palavras das palavras dos teóricos.

I(8) Desenvolver ideias e não só parafraseá-las.

I(9) Concatenação de ideias e frases.

I(10) O estilo de escrita, além do rigor científico do trabalho.

I(11) A insegurança quanto ao domínio da fundamentação teórica.

I(12) Falta de embasamento teórico.

I(13) Falta de referências.

\section{DESCRIÇÃO DA ENTREVISTA}

As dificuldades relacionadas são: a falta de direcionamento quanto aos autores que tratam do assunto; dificuldade de formular o texto sem interferência de autores, de não ter leitura suficiente, ou seja, não ter fundamentação teórica para tal, nem referencial teórico para justificar o texto. A dificuldade também de separar as palavras próprias das palavras dos teóricos, de desenvolver ideias e não só parafraseá-las. A insegurança quanto ao domínio da fundamentação teórica e a falta de embasamento teórico, de referências, todas essas decorrentes da responsabilização do autor-citado, convocado como coenunciador das produções universitárias ou vice-versa.

As outras dificuldades que sobram são de ordem formal: a normalização; a concatenação de ideias; o estilo. Mas, em 
apenas uma ocorrência, um só pesquisador fez referência à dificuldade de lidar com os dados. Pelas regularidades já percebidas na materialidade das produções universitárias e nos episódios de pesquisa, não podemos afirmar que os outros pesquisadores não manifestaram essa preocupação por terem a facilidade de lidar com a pesquisa, mas por não chegar a ser um fato a ser considerado em função de essa não ser uma regularidade do discurso das produções universitárias, marcado por essa ausência.

Dos 13 entrevistados, 9 manifestaram preocupação com o autor e 4, com a forma do texto, o gênero e a normalização.

\section{ANÁLISE DA ENTREVISTA}

Pelos dados acima, observamos que, na pós-graduação, a preocupação com o autor tem alterado a denominação do termo. Há referência também à fundamentação teórica, referencial teórico, palavras dos teóricos, embasamento teórico e referências. Tendo em vista que o pesquisador, ao se referir ao autor, confronta-se com a produção de um texto próprio, inferimos que a manifestação do pesquisador e do autor-citado é intensa. $\mathrm{O}$ objeto está confundido com o assunto; em outra, com o corpus; e, numa terceira, com texto, o que nos permite dizer que a manifestação do objeto entre os pesquisadores foi quase zero. No mais, os pós-graduandos expuseram como maior dificuldade questões formais como normalização, concatenação de ideias e estilo.

EPISÓDIO DE PESQUISA (III): PALAVRAS DE UM PÓSGRADUANDO

Temos pensado sobre as interferências que um sistema de ensino transmissivo ocasiona sobre a produção de conhe- 
cimento e sobre a formação do pesquisador como necessidade fundamental à reprodução social condicionada ao novo que, por sua vez, é condicionado à singularidade nas teleologias secundárias próprias ao trabalho intelectual.

Como analisamos nos Episódios I e II, conversas com graduandos e pós-graduandos respectivamente, temos podido inferir que, na pós-graduação, a necessidade de um autorcitado como ponto de partida para a pesquisa é um desdobramento dessas interferências, uma vez que no ensino superior "pretende-se lidar com o conhecimento sem construí-lo efetivamente" (Severino, 2007, p. 30), através de uma pesquisa sustentada na competência técnico-científica. Selecionamos uma situação de pesquisa que denominamos Episódio III. É o que segue:

Eu recebi um telefonema de um pesquisador marcando uma hora urgente, porque precisava enviar um projeto ao orientador dentro de um prazo muito curto. $\mathrm{Na}$ realidade, ele precisava pensar com alguém sobre o objeto que, naquele momento, não era estranho: era novo e quase desconhecido para ele, em função dos contornos teóricos que se apresentavam no tema.

Perguntei-lhe sobre o que estava fazendo e há quanto tempo: ele me respondeu que era um doutorado que fazia há dois anos. Eu não entendi. Marquei a conversa. De início, perguntei se ele poderia ser meu informante e ele aceitou. Do que me disse, vou fazer a seguinte síntese:

Eu acho que vou largar isso... Já vou pelo $5^{\circ}$ ou $6^{\circ}$ objeto de pesquisa. A área é a mesma, tudo bem... Mas primeiro o objeto era x. Aí comprei um monte de livro de autor que tratasse sobre esse assunto. Depois mudou para y, comprei outros livros de outros. Aí teria que participar de um fórum de pesquisador, como não tinha nada feito, 
escrevi um trabalho com um objeto que se encaixasse mais ao evento. Agora tô pensando neste projeto que quero conversar contigo e já sei... Lá vou ter que comprar mais livro!!! Imagina, já comprei um monte de livro que não vão me servir pra muita coisa...

Observo que aqui a banalização do objeto é decorrente do mesmo olhar que não foi orientado à investigação. Muitas vezes o objeto é inventado em função de uma necessidade imediata das relações burocráticas no ensino universitário. $\mathrm{E}$ isso se repete quando o pesquisador, por exemplo, tem que participar de um fórum de pesquisador: como não tem nada feito, escreve um trabalho com um objeto que se encaixe mais ao evento.

Este é um episódio que se repete nas conversas que nos pomos a investigar. Às vezes, quando perguntamos se "podemos colher de uma conversa um dado para a pesquisa", na maioria das vezes as pessoas não só concordam, mas também afirmam que, onde elas estão fazendo o mestrado e o doutorado, a lamentação é a mesma: "se não fosse uma necessidade de mercado de trabalho, não estariam passando por isso". E isso envolve toda uma atividade de pesquisador para quem aprendeu a ser aluno e professor, na relação transmissiva da aprendizagem nas escolas superiores.

Quanto mais investigamos o processo de produção na universidade, mais identificamos um pesquisador vazio de lugar, do lugar de sua atividade científica criadora, um sujeito sem o espaço de onde ele possa produzir um texto para chamar de seu. Ora: o que temos colhido como dado é consequência de um pesquisador que, muitas vezes, tem que aproveitar a oportunidade que aparece para se qualificar; não conta com a experiência nem com a formação para a escolha do objeto; pensa que o objeto é um produto 
para ser capturado e faz uma escolha acidental; submetese a condições frágeis de um curso de pós-graduação que exige do pesquisador atitudes que ele não tem; começa uma pesquisa muitas vezes também sem contar com o próprio interesse. Não tem tempo para trocar de lente, para refazer sua prática, para contribuir através do sentido de sua pesquisa, para finalmente produzir conhecimento.

EPISÓDIO DE PESQUISA (IV): MARCAS DA CENTRALIDADE DO AUTOR-CITADO NA MATERIALIDADE DO DISCURSO

Apresentamos nas produções universitárias alguns indícios da substituição do lugar do pesquisador, o locutor, aquele que escreve, por um autor-citado, tão indiciária da falta de espaço enfrentada pelo pesquisador quanto ao emprego do se para a indeterminação do sujeito ou para o emprego da passiva. Analisando algumas produções universitárias, selecionamos algumas dessas ocorrências, comentadas no quadro abaixo.

\begin{tabular}{|l|l|}
\hline \multicolumn{1}{|c|}{ MARCAS } & \multicolumn{1}{|c|}{ INFERÊNCIAS } \\
\hline “[... múltiplas situa- \\
ções de leitura e escrita \\
são percebidas e aceitas \\
[...]".
\end{tabular}




\begin{tabular}{|c|c|}
\hline MARCAS & INFERÊNCIAS \\
\hline $\begin{array}{l}\text { "a paráfrase criativa } \\
\text { costuma servir-se do } \\
\text { texto original como } \\
\text { um pretexto }[\ldots] \text { ". }\end{array}$ & $\begin{array}{l}\text { O conceito ocupa o lugar de quem faz. } \\
\text { "A paráfrase criativa costuma servir- } \\
\text {-se", em vez de "o pesquisador costuma } \\
\text { servir-se do texto original ao fazer a pa- } \\
\text { ráfrase criativa". }\end{array}$ \\
\hline $\begin{array}{l}\text { "[...] A leitura segundo } \\
\text { alguém "é uma posição } \\
\text { — imposição - cristã, } \\
\text { bíblica, servil, subser- } \\
\text { viente, pois'[...]" }\end{array}$ & $\begin{array}{l}\text { O autor é substituído por um pronome } \\
\text { indefinido. }\end{array}$ \\
\hline $\begin{array}{l}\text { "Sondagens revelam } \\
{[\ldots] \text { ". }}\end{array}$ & $\begin{array}{l}\text { Aqui o substantivo sondagem, no lugar } \\
\text { do verbo sondar, permite que a ação do } \\
\text { pesquisador fique camuflada. }\end{array}$ \\
\hline $\begin{array}{l}\text { "Nessas práticas, me } \\
\text { despertou curiosidade } \\
\text { tais e tais questões, nos } \\
\text { termos do autor } \mathrm{x} \text { ". }\end{array}$ & A curiosidade é do autor. \\
\hline $\begin{array}{l}\text { “...] Ao tratar da } \\
\text { redação, o autor afirma } \\
\text { que ela é criativa }[\ldots . .] \text {. } \\
\text { O autor lembra tam- } \\
\text { bém [...]". }\end{array}$ & $\begin{array}{l}\text { O autor ocupa o lugar de um Locutor } 2 \\
\text { para agir no lugar dele. }\end{array}$ \\
\hline "O autor x nos ajuda". & $\begin{array}{l}\text { O pesquisador assume a necessidade de } \\
\text { autor. }\end{array}$ \\
\hline
\end{tabular}




\begin{tabular}{|c|c|}
\hline MARCAS & INFERÊNCIAS \\
\hline $\begin{array}{l}\text { "Segundo o pensa- } \\
\text { mento do autor } \\
\text { x... Sua concepção } \\
\text { é [...]". }\end{array}$ & $\begin{array}{l}\text { O pesquisador assume a necessidade } \\
\text { de autor. }\end{array}$ \\
\hline $\begin{array}{l}\text { "Para a realização da } \\
\text { pesquisa os alunos le- } \\
\text { ram os autores }[\ldots . .] " .\end{array}$ & $\begin{array}{l}\text { O autor assume o lugar finalístico da } \\
\text { realização da pesquisa. }\end{array}$ \\
\hline $\begin{array}{l}\text { "Segundo o autor } \mathrm{x}, \\
\text { essa prática limita [...]". }\end{array}$ & $\begin{array}{l}\mathrm{O} \text { autor citado assume os pontos de } \\
\text { vista e as inferências do pesquisador. }\end{array}$ \\
\hline $\begin{array}{l}\text { "Compartilhamos da } \\
\text { ideia do autor x". }\end{array}$ & $\begin{array}{l}\text { A ideia ocupa o lugar do conceito e o } \\
\text { autor, do pesquisador. A ideação está } \\
\text { do lado do pesquisador e não do le- } \\
\text { gado de que faz parte o autor. }\end{array}$ \\
\hline $\begin{array}{l}\text { "[...] é necessário que } \\
\text { professor e aluno le- } \\
\text { vem em consideração } \\
\text { a dinamicidade do } \\
\text { texto,como foi conce- } \\
\text { bido pelo autor x [...]". }\end{array}$ & $\begin{array}{l}\text { Banalização do autor citado por cita- } \\
\text { ções que contêm ideias elementares. } \\
\text { O mesmo acontecendo nas ocorrên- } \\
\text { cias: [...] "o autor x diz que quando se } \\
\text { ensina a ler já se está lendo". / "Pelo } \\
\text { que tais autores disseram, acredita- } \\
\text { mos que se justifica uma observação } \\
\text { mais atenta aos textos [...]". }\end{array}$ \\
\hline $\begin{array}{l}\text { "A leitura dos } \\
\text { autores X, Y } \\
\text { e z é a base para o de- } \\
\text { senvolvimento do tra- } \\
\text { balho [...]". }\end{array}$ & O autor como ponto de partida. \\
\hline $\begin{array}{l}\text { “[...] amparado em } \\
\text { pensadores }[\ldots] " .\end{array}$ & $\begin{array}{l}\text { Confirmação do pesquisador pelo } \\
\text { autor. }\end{array}$ \\
\hline
\end{tabular}




\begin{tabular}{|l|l|}
\hline \multicolumn{1}{|c|}{ MARCAS } & \multicolumn{1}{|c|}{ INFERÊNCIAS } \\
\hline $\begin{array}{l}\text { "Ancorados na análise } \\
\text { do autor x". }\end{array}$ & $\begin{array}{l}\text { O autor como ponto de partida e de } \\
\text { chegada. }\end{array}$ \\
\hline
\end{tabular}

Pela análise das ocorrências materiais do discurso das produções universitárias, neste momento selecionadas, também podemos inferir que, ao mesmo tempo em que o pesquisador responsabiliza o autor-citado, a ausência de seu lugar se manifesta pela necessidade de ser amparado, ajudado e ancorado por ele. Essa distorção compromete a produção de conhecimento porque o pesquisador, como ser social, é quem põe finalidade, através de uma ideação que se expande da subjetividade comprometida a uma singularidade afetada pela dimensão do gênero humano.

No decorrer desta pesquisa, pudemos perceber como desdobramento, na voz dos pesquisadores, também um sentimento de coerção não restrito ao ato de escrever materialmente falando, mas a sua escrita como processo que repercute no ato de produzir um texto. Muitos foram sinalizados no decorrer das reflexões sobre escrita normal e escrita laborativa, no capítulo 3.

Chamaram atenção as determinações das necessidades do pesquisador, afetadas pela lógica de mercado. Mais uma vez percebemos que a singularidade está bloqueada nas produções universitárias, dessimbolizadas pela ausência da condição ontológica de trabalho onde as teleologias secundárias, próprias do trabalho intelectual, são distorcidas pela imediatidade das burocráticas relações universitárias, determinadas por uma função desempenhada "quase exclusivamente no nível burocrático-formal" e "decorrente da própria política educacional do país" (Severino, 2007, p. 29). 
Incluímos aqui as necessidades do pesquisador que põe finalidades através da teleologia e percebemos que elas não estão determinadas por valores ontológicos postos nas relações concretas de transformação da sociedade pela emancipação do pesquisador, mas por determinações políticas da necessidade do título, ou para acesso ao mercado de trabalho ou para ascensão na carreira do magistério.

Essa urgência do título promove o discurso da necessidade imediata de qualificação e afeta a escolha entre alternativas, condição da singularidade, porque o pesquisador é, em grande parte, movido pela oportunidade que muitas vezes lhe tira a possibilidade de escolher, o que é condição para a representação e não para a produção do conhecimento.

Nesse caso, as produções universitárias têm sido a negação do que é ontológico à categoria trabalho, fundante do ser social (Lukács, 1981). Essas produções são dessimbolizadas (Dufour, 2005), perdem o seu sentido fundamental. Como elas reúnem, entre seus elementos, o pesquisador cuja subjetividade é fundante e a construção do objeto como possibilidade de transformação social, acontece a dessimbolização de todos esses lugares e, em consequência, a "precarização" (Antunes, 2007, p. 209-210) da pesquisa pela negação da produção de conhecimento.

Questões burocráticas, como necessidade de título, lugar no mercado de trabalho, além do ensino transmissivo, afetam as produções universitárias na medida em que perdem a dimensão de teleologias secundárias como complexificação do trabalho primário, condição do ser social, que se funda pelo pôr o novo da reprodução social.

Esse novo não produzido na universidade, por causa da representação do conhecimento, elimina das produções universitárias o sentido da pesquisa como condição da singularidade do pesquisador e vice-versa. 
Para poder construir mais um ângulo da interferência na expressão da singularidade do pesquisador, tendo em vista que essas interferências se fundam nas necessidades que, por sua vez, sofrem determinações da exterioridade, estivemos reunidos com um grupo de pesquisadores num curso de especialização e perguntamos a eles o motivo de estarem ali, num final de semana, a despeito de toda a semana de trabalho. Cada um elencou por escrito suas necessidades que puderam ser lidas e analisadas como indícios ou marcas próprias de um discurso próprio às produções universitárias.

Essa pergunta é oportuna porque, pela depreensão do conceito de trabalho das produções universitárias, relacionamos o pôr teleológico, ou das finalidades, às necessidades, às escolhas entre alternativas como nexos internos determinantes de uma pesquisa cheia de sentido e associamos a tudo isso o sentido como consequência do impulso ou da pulsão, essenciais para o mover do pesquisador na direção de um objeto a ser construído para, pelo novo como condição do trabalho, acontecer a necessária reprodução social, condição da transformação e da emancipação.

Algumas contingências dos pesquisadores:

\begin{tabular}{|l|c|c|c|}
\hline $\begin{array}{c}\text { INFOR- } \\
\text { MANTE }\end{array}$ & $\begin{array}{c}\text { PROD. DE } \\
\text { CONHECI- } \\
\text { MENTO }\end{array}$ & $\begin{array}{c}\text { REPRESENTAÇÃO } \\
\text { DO }\end{array}$ & $\begin{array}{c}\text { INTERESSES } \\
\text { CONHECIMENTO }\end{array}$ \\
\hline & & & QuROCRÁTICOS \\
\hline I(1) & & & Qualificação \\
& & & profissional para o \\
& & & mercado de trabalho/ \\
& & & Fazer Mestrado/ \\
& & & Buscar formas de \\
& & & trabalhar a disciplina LP \\
\hline
\end{tabular}




\begin{tabular}{|c|c|c|c|}
\hline $\begin{array}{l}\text { INFOR- } \\
\text { MANTE }\end{array}$ & $\begin{array}{l}\text { PROD. DE } \\
\text { CONHECI- } \\
\text { MENTO }\end{array}$ & $\begin{array}{l}\text { REPRESENTAÇÃO } \\
\text { DO } \\
\text { CONHECIMENTO } \\
\end{array}$ & $\begin{array}{c}\text { INTERESSES } \\
\text { BUROCRÁTICOS }\end{array}$ \\
\hline $\mathrm{I}(2)$ & & $\begin{array}{l}\text { Adquirir novos } \\
\text { conhecimentos }\end{array}$ & $\begin{array}{c}\text { Meio de acréscimos de } \\
\text { salário }\end{array}$ \\
\hline I(3) & & $\begin{array}{l}\text { A busca do } \\
\text { conhecimento } \\
\text { relativo à disci- } \\
\text { plina escolhida }\end{array}$ & $\begin{array}{c}\text { Garantir melhores } \\
\text { oportunidades no mer- } \\
\text { cado de trabalho/seguir } \\
\text { carreira }\end{array}$ \\
\hline I(4) & & $\begin{array}{l}\text { Preciso con- } \\
\text { tinuar minha } \\
\text { vida estudantil }\end{array}$ & $\begin{array}{c}\text { Realizar meu trabalho } \\
\text { pela capacitação }\end{array}$ \\
\hline I(5) & & $\begin{array}{l}\text { Aprofunda- } \\
\text { mento nos } \\
\text { estudos }\end{array}$ & $\begin{array}{c}\text { Crescimento profissio- } \\
\text { nal e pessoal }\end{array}$ \\
\hline I(6) & & $\begin{array}{l}\text { Buscar novas } \\
\text { informações } \\
\text { sobre o estudo } \\
\text { da língua por- } \\
\text { tuguesa }\end{array}$ & $\begin{array}{l}\text { Melhorar minha práti- } \\
\text { ca, meu ensino }\end{array}$ \\
\hline $\mathrm{I}(7)$ & & & $\begin{array}{l}\text { Continuar os estudos } \\
\text { para não ficar à margem }\end{array}$ \\
\hline
\end{tabular}


ESCRITA NO ENSINO SUPERIOR

\begin{tabular}{|c|c|c|c|}
\hline $\begin{array}{l}\text { INFOR- } \\
\text { MANTE }\end{array}$ & $\begin{array}{l}\text { PROD. DE } \\
\text { CONHECI- } \\
\text { MENTO } \\
\end{array}$ & $\begin{array}{c}\text { REPRESENTAÇÃO } \\
\text { DO } \\
\text { CONHECIMENTO }\end{array}$ & $\begin{array}{c}\text { INTERESSES } \\
\text { BUROCRÁTICOS }\end{array}$ \\
\hline I(8) & $\begin{array}{c}\text { Alargar as } \\
\text { fronteiras de } \\
\text { um simples } \\
\text { saber fazer/ } \\
\text { Desconstru- } \\
\text { ção/cons- } \\
\text { trução que } \\
\text { auxiliem o } \\
\text { meu projeto } \\
\text { de Mestrado }\end{array}$ & & \\
\hline I(9) & & $\begin{array}{c}\text { Ampliar meus } \\
\text { conhecimentos } \\
\text { sobre a língua/ } \\
\text { Sou preguiçosa } \\
\text { para estudar so- } \\
\text { zinha e fazendo } \\
\text { curso preciso } \\
\text { ler e estudar } \\
\text { mais }\end{array}$ & \\
\hline $\mathrm{I}(10)$ & & $\begin{array}{l}\text { Buscar conheci- } \\
\text { mentos }\end{array}$ & $\begin{array}{l}\text { Profissional capacitado } \\
\text { para melhor valori- } \\
\text { zação no mercado de } \\
\text { trabalho }\end{array}$ \\
\hline
\end{tabular}




\begin{tabular}{|c|c|c|c|}
\hline $\begin{array}{l}\text { INFOR- } \\
\text { MANTE }\end{array}$ & $\begin{array}{c}\text { PROD. DE } \\
\text { CONHECI- } \\
\text { MENTO }\end{array}$ & $\begin{array}{l}\text { REPRESENTAÇÃO } \\
\text { DO } \\
\text { CONHECIMENTO } \\
\end{array}$ & $\begin{array}{c}\text { INTERESSES } \\
\text { BUROCRÁTICOS }\end{array}$ \\
\hline $\mathrm{I}(11)$ & & $\begin{array}{l}\text { Obtenção de } \\
\text { novos conhe- } \\
\text { cimentos/ um } \\
\text { estudo mais } \\
\text { aprofundado da } \\
\text { língua }\end{array}$ & Salário \\
\hline $\mathrm{I}(13)$ & $\begin{array}{l}\text { Retomar o } \\
\text { interesse } \\
\text { pela pesqui- } \\
\text { sa de assun- } \\
\text { tos já vistos } \\
\text { e novos }\end{array}$ & & $\begin{array}{l}\text { Visar à docência } \\
\text { superior }\end{array}$ \\
\hline I(14) & & $\begin{array}{l}\text { Obter mais } \\
\text { conhecimentos }\end{array}$ & $\begin{array}{l}\text { Garantir uma estabili- } \\
\text { dade melhor no campo } \\
\text { profissional/ } \\
\text { Procurar uma posição } \\
\text { melhor financeira e me } \\
\text { estruturar no futuro }\end{array}$ \\
\hline I(15) & & $\begin{array}{l}\text { Dar continuida- } \\
\text { de aos estudos/ } \\
\text { Ampliar conhe- } \\
\text { cimentos }\end{array}$ & $\begin{array}{l}\text { Exigência do mercado/ } \\
\text { Campo de trabalho }\end{array}$ \\
\hline
\end{tabular}


ESCRITA NO ENSINO SUPERIOR

\begin{tabular}{|l|c|c|c|}
\hline $\begin{array}{c}\text { INFOR- } \\
\text { MANTE }\end{array}$ & $\begin{array}{c}\text { PROD. DE } \\
\text { CONHECI- } \\
\text { MENTO }\end{array}$ & $\begin{array}{c}\text { REPRESENTAÇÃo } \\
\text { DO } \\
\text { CONHECIMENTO }\end{array}$ & $\begin{array}{c}\text { INTERESSES } \\
\text { BUROCRÁTICOS }\end{array}$ \\
\hline I(16) & $-\begin{array}{c}\text { Adquirir } \\
\text { conhecimentos } \\
\text { na minha área } \\
\text { de formação }\end{array}$ & $\begin{array}{c}\text { Melhorar minha prática } \\
\text { Pedagógica }\end{array}$ \\
\hline I(17) & $-\begin{array}{c}\text { Melhorar os } \\
\text { conhecimentos } \\
\text { linguísticos }\end{array}$ & Ampliar o currículo \\
\hline
\end{tabular}

O que queríamos mesmo investigar era o interesse do pesquisador: se pela produção de conhecimento ou pela representação do conhecimento ou ainda se o interesse era burocrático por envolver interesses trabalhistas e institucionais. Ou seja: por que se produzem monografias, dissertações e teses na universidade?

Consideramos interesse pela produção de conhecimento qualquer manifestação sobre pesquisa, dado, análise de dados, atividade de pesquisador e, como representação, tudo o que se refere a conhecimento na direção de citar autores, como se eles guardassem o trabalho do pesquisador já pronto para ser apenas encontrado e adquirido, através de outras ações como a de aprofundar, de estudar, ocorrências que indicam algo pronto a ser recebido e não construído.

A noção de estudar no lugar de ler é indício do ensino transmissivo, pelo qual o aluno estuda o que o professor repassou, muitas vezes só pela atitude de memorização. Isso muitas vezes faz com que haja a sensação de não se sentir capaz de "estudar sozinho", porque estudar está dissociado de ler. Destacamos alguns desses indícios na fala de pesquisadores, conforme é possível ver em "dar continuidade aos estudos"; 
"adquirir conhecimentos na área de formação"; "melhorar os conhecimentos linguísticos". O conhecimento, conforme o destacado acima, é algo que, pela ação de buscar, obter, adquirir, através do estudo, está como algo pronto a ser capturado.

E o curso como possibilidade de acesso à carreira do magistério, como meio de melhoria salarial, de permanência no mercado ou melhoria de uma prática escolar, é, sem dúvida, um interesse burocrático que não avança da subjetividade do pesquisador, na dimensão mais pessoal possível, e é externa a toda expectativa de reprodução social, porque o interesse pela pesquisa não acontece, a não ser mencionado em uma única vez, de forma equivocada.

Em síntese, das necessidades e finalidades dos informantes sobre qualificação, 50\% manifestaram interesse burocrático; $43 \%$ priorizaram a representação do conhecimento e apenas $7 \%$ fizeram alguma menção à pesquisa.

Como podemos inferir, a regularidade incide sobre o interesse burocrático e depois sobre a representação do conhecimento. Mesmo sabendo que ambos recebem influências diferentes da exterioridade, não podemos negar que o interesse burocrático é mais um agravante que alimenta a representação e não a produção que se manifesta minimamente.

EPISÓDIO DE PESQUISA (v): A DESSIMBOLIZAÇÃO DAS PRODUÇÕES UNIVERSITÁRIAS

No discurso dos pesquisadores quanto à finalidade de suas pesquisas, é bastante regular a necessidade de qualificação como exigência de mercado. Qualquer outro sentido geralmente é secundário. A seguinte afirmação de um pesquisador é um dado dessa interferência: 
No meu grupo (e nós já estamos fazendo o doutorado), eu garanto que $90 \%$ dos doutorandos estão fazendo a pesquisa por questões salariais e para garantir um lugar no mercado de trabalho.

Se são essas as prioridades, chega o momento de entender o sentido de não mais pensar que o pesquisador consome, mas que é consumido. Muito mais já é possível dizer: a lógica de mercado é consumidora, quando, necessitado do título para o incentivo salarial, o pesquisador revela não saber qual é mesmo o lugar de sua paixão no processo de pesquisa e, em consequência, o seu espaço no que produz na universidade.

As produções universitárias, dessimbolizadas, tornam-se mercadorias para a circulação no mercado numa produção em série. Assim, são produzidas para consumo imediato e não cumprem o destino da reprodução social, fato que devora a possibilidade de emancipação do ser social como responsável pela produção do novo e favorece a representação do conhecimento, ou seja, a reposição do mesmo da esfera biológica.

A voz dos pesquisadores que estão produzindo aumenta a angústia de escrever, que não é a de confrontar-se com o reflexo, mas a da desconfiguração do objeto de pesquisa, que, muitas vezes dessimbolizado, torna-se estranho ao pesquisador, face à finalidade priorizada.

Conversando com um pesquisador, perguntamos: "mas como é mesmo ter que fazer uma pesquisa distante do que se viu durante todo um tempo de trabalho?" E ele respondeu:

A gente acaba se acostumando e muitos até se envolvem, mas tem muita gente no meu grupo de doutoramento que está pesquisando sobre algo bem distante... Se não fosse a necessidade de aumento salarial, duvido que estariam ali. E isso lá todo mundo fala mesmo. 
Uma das consequências das finalidades imediatistas para a pesquisa é a dessimbolização da teoria, quando ela não é recebida como exemplar de um paradigma - alguma lente através da qual o mundo se reconfigura. Por exemplo: temos observado que o autor é citado de forma equivocada, fragmentado nas citações exigidas pelos manuais científicos para a produção universitária, numa leitura muitas vezes terceirizada. Importa que haja teoria para a análise dos dados, mas, em função das circunstâncias em que a pesquisa se estrutura, não há escolha para o pesquisador aceitar ou não uma teoria, restringindo a atitude de escrever ainda mais à responsabilização de um autor. Isso gera a fragmentação da lente, tão necessária ao sentido da pesquisa e aos efeitos desse sentido na construção do objeto.

Nesse caso, o contexto neoliberal, propício às finalidades burocráticas do pesquisador, manifesta-se através de um discurso sinalizado nas produções universitárias: um discurso não só vazio do lugar do sujeito, mas vazio de desejo, e, em consequência, vazio de impulso, de pulsão, de paixão e de produção de conhecimento, porque as produções universitárias em série não são condicionadas pela singularidade. Essa falta de alternativa faz com que seja possível encontrar como regularidade o dado seguinte: "Eu acho que vou largar isso [...]".

Este é um episódio que se repete nas conversas que nos pusemos a investigar. Às vezes perguntamos: "podemos colher dessa nossa conversa um dado para a nossa pesquisa?” E, na maioria, as pessoas não só concordam, mas também afirmam que lá por onde elas estão fazendo o mestrado e o doutorado a insatisfação é a mesma: "se não fosse uma necessidade de mercado de trabalho, não estariam passando por isso".

Percebemos também que, quando a necessidade é imediata, consumível, quando se confunde com satisfação imediata, a insatisfação do pesquisador é maior, mesmo que ele 
ESCRITA NO ENSINO SUPERIOR

encontre a saída da escrita normal que não lhe exige o dilema essencial próprio do trabalho de escrita. 
8. Monografias: há outro caminho? 
Depois de pensarmos o sentido da pesquisa, refletindo sobre as finalidades postas pelo pesquisador; depois de nos colocarmos à escuta dessas finalidades, ouvindo os porquês e as determinações das pesquisas e as circunstâncias determinantes dos processos pelos quais elas se realizam na universidade, apresentamos a seguir o que encontramos como traços comuns das monografias. Estamos chamando de monografia os trabalhos de conclusão de curso produzidos pelos graduandos.

Selecionamos mais monografias para apresentar nesta publicação do que dissertações ou teses, porque suas marcas vão se desdobrar de alguma forma nos níveis subsequentes, em função de toda uma prática que se refletirá posteriormente no mestrado e no doutorado.

A leitura das monografias para identificar as marcas de representação ou de produção do conhecimento possibilitou gerar um quadro demonstrativo dessas marcas. Tendo selecionado, aleatoriamente, as 20 monografias de 2001 a 2008, decidimos fazer uma quantificação de páginas que não dispensou a leitura de cada uma. Foi um modo que encontramos para tratar, com maior precisão, o que é impreciso nessas regulari- 
dades porque não estão especificamente na materialidade das produções universitárias, mas em atitudes nelas manifestas.

Estamos tomando como atitude, por exemplo, a decisão do pesquisador de contar uma longa história da música desde os primeiros habitantes da Terra, ou da história da língua portuguesa desde o Latim, para construir uma visão do ensino de Língua Portuguesa numa determinada realidade, quer seja pelas letras de música, quer seja pela necessidade da morfologia.

Consideramos decisão também o fato de um pesquisador, para tratar do ensino de língua, ter que passar por todas as concepções de gramática, repetindo um conhecimento produzido, por exemplo, sobre conceitos, tipos de gramática, sem que escolha um para construir o objeto. Algumas vezes, em pouquíssimas páginas, por exemplo, é dito algo sobre a escola $\mathrm{X}$, descrita, em grande parte, pelas suas instalações.

\begin{tabular}{|c|c|c|}
\hline MONOGRAFIA & PUBLICAÇÃo & OBJETO \\
\hline M1 & 2001 & Ensino de LP \\
\hline M2 & 2007 & Intertextualidade \\
\hline M3 & 2007 & Aquisição de linguagem \\
\hline M4 & 2007 & Leitura \\
\hline M5 & 2008 & Inteligência poética \\
\hline M6 & 2008 & Ensino de LP \\
\hline M7 & 2002 & Alfabetização \\
\hline M8 & 2006 & Alfabetização \\
\hline M9 & 2004 & Leitura \\
\hline M10 & 2006 & Leitura \\
\hline
\end{tabular}


ESCRITA NO ENSINO SUPERIOR

\begin{tabular}{|c|c|c|}
\hline MONOGRAFIA & PUBLICAÇ̃̃o & OBJETO \\
\hline M11 & 2004 & Ensino de LP \\
\hline M12 & 2004 & Ensino de LP \\
\hline M13 & 2001 & Escrita \\
\hline M14 & 2003 & Escrita \\
\hline M15 & 2006 & Ensino de LP \\
\hline M16 & 2005 & Leitura \\
\hline M17 & 2005 & Leitura e escrita \\
\hline M18 & 2005 & Formação de leitores \\
\hline M19 & 2005 & Imagem e texto \\
\hline M20 & 2006 & Gêneros textuais \\
\hline
\end{tabular}

Essas monografias, como pode ser visualizado no quadro acima, foram produzidas, aproximadamente, no intervalo de uma década, o que possibilita não apenas ver como se dá a prática do pesquisador-graduando no processo de finalização de seu curso, como confrontar essa prática com o que foi posto filosoficamente sobre o ser social cuja protoforma é o trabalho que, na universidade, é a produção do novo através das produções universitárias: monografias, dissertações e teses.

Tendo em vista esses traços comuns, construímos as categorias que se repetem com certa regularidade e organizamos a seguinte classificação: sobre a responsabilização do autorcitado - conjunção normal, conjunção estilizada, conjunção por hiperônimo, citação plural, articulação prescritiva. Sobre a construção do objeto: emprego de palavra evasiva, introdução 
evasiva, historicização do objeto, minimização da pesquisa, desvio das finalidades.

RESPONSABILIZAÇÃO DO AUTOR-CITADO

Durante a entrevista com graduandos, percebemos que a preocupação maior declarada por eles foi a de encontrar um autor, de preferência lido pelo orientador, para fazer parte da fundamentação. Um autor que deveria dar margem para a realização da continuidade, própria da reprodução social.

Mas consideramos por bem analisar se a referida participação do autor realmente concretiza esse ir para outro lugar através do conceito ou se, ao invés disso, limita a reprodução social pela citação de frases de efeito ou mesmo pela responsabilização de um autor para dizer o que o pesquisador, o graduando, não se sente autorizado a fazer.

Isso acontece na graduação pelas seguintes marcas que geraram a seguinte classificação: conjunção normal, conjunção estilizada, conjunção por hiperônimo, citação plural, articulação prescritiva.

- conjunção normal. Estamos chamando de conjunção normal a articulação que se dá entre a voz do pesquisador-graduando e a voz do autor-citado, através das conformativas. Exemplo:

Segundo o autor $\mathrm{x} .$.

- conjunção estilizada. No caso da conjunção estilizada, a articulação entre a voz do pesquisador e a do autor acontece por uma tentativa de se desviar das conformativas, usando palavras e expressões diferentes e mais elaboradas, talvez como possibilidade de legitimar o lugar próprio pelo estilo. 
Exemplos:

Na afirmação Yniana [...].

Estou citando y para dizer $\mathrm{x}$.

Ainda nas palavras do autor $\mathrm{x}$.

Como já falou acerca disso $\mathrm{x}[. .$.$] .$

$\mathrm{Na}$ perspectiva de $\mathrm{X}$ e $\mathrm{Y}$.

- conjunção por hiperônimo. O modo como o autor-citado é convocado nas produções universitárias é indício de como o pesquisador se posiciona frente a essa presença responsabilizada. Ou ele cita para dizer de novo o que o autor disse, ou ele diz para o autor confirmar. Quem acredita, quem pensa, quem afirma, quem defende é o autor, ficando a cargo do pesquisador citá-lo. No caso da articulação por hiperônimo, o pesquisador trabalha com a palavra hiperonímica, mas responsabiliza o autor para preenchê-lo. Exemplos:

Assim, o curso da discussão se volta para os condicionamentos sofridos pelo professor nos dias de hoje, que o afetam enquanto leitor e enquanto sujeito que lança mão da leitura ao longo de suas práticas pedagógicas. Segundo Y [...], “[...] há seis condicionamentos: salário, formação acadêmica, múltiplas funções da mulher professora, currículo, especialistas e ideologias" que, "quando não percebidos criticamente, podem gerar consequências nefastas [...]”.

Acima, a articulação entre a voz do pesquisador e a do autor-citado é a palavra condicionamentos, que é um hiperônimo, ou seja, aquele termo que guarda "o sentido do todo" (Dubois et al., 1993, p. 323). O pesquisador trata vagamente dos condicionamentos "sofridos pelo professor nos dias de hoje", mas quem preenche o vazio desse hiperônimo é o autor. $\mathrm{O}$ pesquisador anuncia para que o autor-citado diga. Percebemos 
esta ocorrência mais como uma opotunidade criada pelo pesquisador para a convocação do autor. Ele enumera evidências da realidade, fatos visíveis que o pesquisador mesmo estaria autorizado a ver e a dizer.

- citação plural. Esse tipo de articulação entre a voz do pesquisador e a voz do autor caracteriza-se pela atitude de citar dois ou mais autores para confirmar algo que o pesquisador poderia estar autorizado a dizer. Exemplos:

Não se pode falar em aprendizado sem a prática da vivência dos fatos. Dessa forma, a cultura torna-se parte da natureza humana.

Afirma-se ainda que, segundo o autor x [...], é a cultura que fornece ao indivíduo os sistemas simbólicos da realidade [...].

Segundo o autor $\mathrm{Y}$, o indivíduo internaliza formas culturalmente dadas.

Quando o pesquisador convocou dois autores-citados, na verdade ele pretendia que esses autores confirmassem o sentido de prática das vivências dos fatos, algo sobre cultura. Pelo que pudemos perceber, o pesquisador repete "a prática das vivências dos fatos" em "natureza humana num processo histórico"/ "sistemas simbólicos da realidade"/ "internalização de formas culturalmente dadas". Percebemos ainda, sem desmerecer o que os autores-citados dizem, que o pesquisador não necessitaria convocar outros locutores para dizer a partir de uma sinalização que já está feita sobre cultura e que chega perto do senso comum.

- articulação prescritiva. Quanto à responsabilização do autor-citado pelo pesquisador, acontece também de ela gerar 
uma espécie de prescrição para descrever algum dado a partir do qual o autor prescreve. Por exemplo: se o autor-citado pensa $\mathrm{X}$, o pesquisador vai avaliar se o dado se comporta de acordo com o pensamento dele. Exemplo:

O objetivo precípuo destas análises é avaliar se as aulas de Língua Portuguesa na referida escola estão sendo ministradas de acordo com o objetivo de linguistas como os já citados.

O pesquisador supõe algo pronto, prescrito pelo autor-citado, no caso os linguistas, e, "de acordo com o objetivo de linguistas como os já citados", vai em busca de encontrar o modelo.

Acreditamos ser isso uma consequência do ensino transmissivo que favorece a representação do conhecimento. Significa que, se os professores portam o saber dos autores, as informações sobre o mundo, o conhecimento produzido, pronto e dado, isso basta para que apenas os teóricos estejam autorizados a dizer. É também bastante regular entre as produções universitárias outra marca: a da possibilidade de concluir após toda a revisão bibliográfica e não após a análise dos dados a partir da teoria.

Em síntese, há autores responsabilizados pelas reflexões presentes nas produções universitárias, o que nos faz questionar a singularidade do trabalho que o pesquisador assina.

A CONSTRUÇÃo DO OBJETO

De acordo com o que temos percebido durante a análise das produções universitárias, no momento em que o autorcitado assume o lugar central dessas produções, o olhar do pesquisador desvia-se da direção do objeto. Há também a eliminação da possibilidade de produzir esse objeto e a consequente representação do conhecimento. 
Neste caso, o pesquisador, ao objetivar sua produção escrita, contorna o objeto através dos seguintes indícios que constituíram a classificação já mencionada: emprego de palavra evasiva, introdução evasiva, minimização da pesquisa e historicização do objeto.

- emprego de palavra evasiva. Consideramos palavras evasivas aquelas de sentido vago. Chamou nossa atenção a grande incidência do termo abordagem nas produções universitárias e esta curiosidade nos fez questioná-la na relação com outros indícios, aqui postos, e na relação também com a sempre associação de abordagem a uma outra atitude: a de estar sendo superficial por algum lugar da pesquisa.

O pesquisador, ao realizar uma escrita, declara que "fará uma abordagem", e, geralmente, "não pretende fazer uma abordagem aprofundada", ou naquela produção apresenta uma abordagem ou uma problemática, ou constatações diversas sobre um assunto que não é tratado como um objeto de investigação.

Selecionamos esse termo preferencialmente, primeiro pelo motivo já exposto, de que é uma palavra presente em grande número das monografias lidas. Segundo, porque traz em si o sentido de borda, de margem, como se a pesquisa se desse pelas bordas de um objeto muitas vezes apagado. Abordar é aproximar, encostar, chegar à margem. Encontramos, neste caso, outra marca de representação do objeto: algo parece estar pronto, só havendo possibilidade de aproximação e não de construção, mais uma vez criando o contexto de uma pesquisa que aborda, aproxima, chega perto e apenas contorna o objeto sem construí-lo pela produção de conhecimento, porque a borda é de algo que já existe. 
- introdução evasiva. Outra marca evasiva que facilita a atitude de abordar é uma introdução genérica que se adapta a qualquer objeto. Escrever sobre o mundo como introdução de monografias, indiferentemente do assunto, quer seja sobre ensino de português, música na aula de português, ou produção escrita no ensino médio, foi uma regularidade entre as monografias que lemos. Estamos nos referindo a uma contextualização sócio-política que se repete em monografias (entre 2001 a 2006) de temas completamente diferentes, como se muitas delas começassem do mesmo modo. Exemplos:

Atualmente, com o avanço tecnológico presenciado, parece inacreditável que na sociedade se tenha de buscar alternativas para um melhor confronto com os diversos desafios que cercam o ser humano, afastando-o das possibilidades de participação pelo trabalho. Quanto à educação que, historicamente, neste país, tem sido tema de discussões para a melhoria qualitativa do ensino, ainda se ressente de uma série de implementos para, realmente, poder garantir uma formação sustentável e necessária à convivência e interação humana, mesmo num mundo social capitalista. (Trecho de introdução de monografia sobre ensino de LP, produzida em 2001).

As urgências do mundo moderno exigem qualidade de ensino, buscando formar cidadãos capazes de interferir criticamente na sua realidade imediata para transformá-la. Para que isso aconteça, de fato, é necessário oferecer ao aluno mecanismos que lhe assegurem o desenvolvimento de capacidades para se apropriar da gama de conhecimentos e informações presentes nos currículos escolares, levando-os a compreenderem as complexas condições competitivas do mercado de tra- 
balho na sociedade capitalista em que vivemos. (Trecho de introdução de monografia sobre MPB na aula de LP, produzida em 2004).

O mundo contemporâneo, marcado fortemente pelo inesperado avanço tecnológico e por grandes mudanças nas relações sociais e do trabalho, exige uma educação voltada para o desenvolvimento de competências cognitivas e culturais que ofereça ao educando tanto o exercício de sua cidadania quanto o desempenho de atividades profissionais de forma eficiente, garantindo-lhe participação social, como sujeito consciente e crítico, capaz de estabelecer relações de interação e de transformação com a comunidade em que vive. (Trecho de introdução de monografia produzida em 2006 sobre a produção escrita no ensino médio).

$\mathrm{Na}$ próxima página, exemplificamos as temáticas recorrentes entre as monografias e as marcas abrangentes de suas introduções. Em síntese, vemos que uma monografia de 2001 , outra de 2004 e outra de 2006 começam com o mesmo conteúdo e têm temáticas diferentes. Uma emprega "atualmente"; a outra, "mundo moderno"; a outra, ainda, "mundo contemporâneo". Uma emprega "mundo capitalista"; a outra, "mercado de trabalho"; a outra, "mundo tecnológico". O início das monografias tem muita semelhança, independentemente do objeto. 


\begin{tabular}{|c|c|c|c|}
\hline & \multicolumn{3}{|c|}{ MONOGRAFIA } \\
\hline & 2001 & 2004 & 2006 \\
\hline ASSUNTO & Ensino de LP & $\begin{array}{l}\text { MPB na aula } \\
\text { de LP }\end{array}$ & $\begin{array}{l}\text { Produção escrita } \\
\text { no ensino médio }\end{array}$ \\
\hline 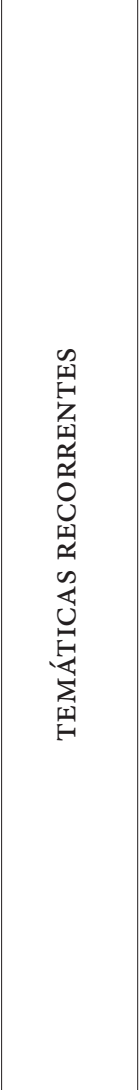 & $\begin{array}{l}\text { Atualmente, } \\
\text { avanço tec- } \\
\text { nológico/ } \\
\text { con f r o n to } \\
\text { com os diver- } \\
\text { sos desafios } \\
\text { que cercam o } \\
\text { ser humano/ } \\
\mathrm{m} \text { e l h o r i a } \\
\text { qualitativa do } \\
\text { ensino/ } \\
\text { garantia de } \\
\text { uma for- } \\
\text { mação sus- } \\
\text { tentável e } \\
\text { necessária à } \\
\text { convivência e } \\
\text { interação hu- } \\
\text { mana } \\
\text { num mundo } \\
\text { social capita- } \\
\text { lista. }\end{array}$ & $\begin{array}{l}\text { Mundo moder- } \\
\text { no/ formação de } \\
\text { cidadãos capa- } \\
\text { zes de interferir } \\
\text { criticamente na } \\
\text { sua realidade } \\
\text { imediata para } \\
\text { transformá-la/ } \\
\text { necessidade de } \\
\text { oferecer ao alu- } \\
\text { no mecanismos } \\
\text { que lhe assegu- } \\
\text { rem o desenvol- } \\
\text { vimento de ca- } \\
\text { pacidades } \\
\text { levando-os a } \\
\text { co mp re en de- } \\
\text { rem as comple- } \\
\text { xas condições } \\
\text { competitivas do } \\
\text { mercado de tra- } \\
\text { balho na socie- } \\
\text { dade capitalista }\end{array}$ & $\begin{array}{l}\text { O mundo contem- } \\
\text { porâneo/ marcado } \\
\text { fortemente pelo } \\
\text { inesperado avanço } \\
\text { tecnológico exi- } \\
\text { ge uma educação } \\
\text { voltada para o de- } \\
\text { senvolvimento de } \\
\text { competências cog- } \\
\text { nitivas e culturais } \\
\text { que ofereça ao edu- } \\
\text { cando o exercício de } \\
\text { sua cidadania/ neste } \\
\text { mundo, é através } \\
\text { da linguagem que } \\
\text { o sujeito interpreta } \\
\text { e constrói signifi- } \\
\text { cados que o permi- } \\
\text { tem interagir com } \\
\text { o mundo/ o mundo } \\
\text { hodierno requer, } \\
\text { por parte do indi- } \\
\text { víduo, um domínio } \\
\text { cada vez maior das } \\
\text { linguagens como } \\
\text { instrumento de co- } \\
\text { municação e nego- } \\
\text { ciação de sentidos. }\end{array}$ \\
\hline
\end{tabular}


- historicização do objeto. Percebemos que há uma certa regularidade na historicização do objeto. Se a pesquisa é sobre a MPB nas aulas de Língua Portuguesa, a história se prolonga só sobre a MPB. Além disso, se a pesquisa inclui a MPB na sala de aula, a história poderia ser contada, sim, para ver a partir de qual momento a escola se abre para a possibilidade de utilizar as letras para analisar o jogo da língua portuguesa. Só que, com certa regularidade, as monografias se baseiam em descrições históricas de uma parte daquilo que se propõem a pesquisar.

Percebemos inclusive que a historicização é meio frutífero de representação do objeto. Analisamos esta marca, a princípio, entre duas monografias que tratam do mesmo tema. Uma produzida em 2004 e a outra, em 2006.

A monografiag (M9), sobre contos de fada no livro didático, produzida em 2004, conta a história desses contos e descreve-os pela obra de um autor que marca a literatura infantil brasileira, buscando seus elementos caracterizadores, por exemplo, o maravilhoso. Retira, teoricamente desses contos, algumas outras características. É indício de desvio do objeto o fato de o autor escolhido estar relacionado à história da literatura infantil no Brasil e não ao conto de fada. É também indício o fato de essa historicização se dar da página 11 à página 42. O conto de fada é tratado em si e não em sua relação com o livro didático. É o que estamos chamando de fragmentação.

A monografia1o (M10), sobre contos de fada e ensino, produzida em 2006, inicia-se também pelas origens, mistura um pouco de suas funções e depois descreve o conto de fada, caracterizando-o por suas temáticas, seus tons, seus elementos. O conto de fada é tratado em si e não em sua relação com o ensino. É o que estamos chamando de fragmentação. Uma monografia, por exemplo, sobre os contos de fada, que procura relacioná-los à formação do leitor, através do ensino, conta 
a história do conto de fada da página 10 à página 33 e relaciona o conto de fada a ensino nas páginas 37 e 38 .

Tendo relacionado a monografiag ( $\mathrm{M9}$ )e a monografiaıo (M10) quanto à historicização do objeto fragmentado, por se tratarem do mesmo tema, pudemos perceber que as diferenças não constituem singularidade. São diferenças de estilo de escrever: a de 2004 trata das raízes do conto de fada; e a de 2006 , das origens. São modos diferentes de dizer o já-produzido na cultura. As diferenças entre escola e livro didático só estão no título, porque o pesquisador, ao se propor a tratar dos livros didáticos, refere-se ao âmbito escolar, ou seja, ambas contextualizam a leitura desses contos na escola.

Mas, mesmo quando os objetos a serem pesquisados na escola são diferentes dos contos de fada, a regularidade da historicização do objeto manifesta-se. Por exemplo: a monografia8 (M8) sobre alfabetização de jovens e adultos, produzida em 2006, conta a história da alfabetização, remontando a alguns séculos, passando pela Primeira República, Período Vargas, Período Militar, Nova República, até localizar Paulo Freire para lançar um olhar para hoje.

A pesquisa só existe referenciada nas páginas 30 e 31, mas a história começa na página 2 e vai até a página 29. Outra monografia, a monografia7 ( $\left.\mathrm{M}_{7}\right)$, produzida em 2002, que também trata da alfabetização pela teoria construtivista, além de relacionar os aspectos da realidade, faz um passeio histórico pelas várias teorias existentes e só faz referência à investigação na página 49, sem que haja alguma análise de dados.

Ainda sobre a historicização do objeto fragmentado, a monografia11 (M11), ao propor uma leitura do ensino do Português numa determinada escola, desvia-se dessa perspectiva tanto quanto as outras monografias analisadas, ao reservar boa parte de suas páginas à história interna e externa da língua portuguesa, voltando aos primeiros fatos do Latim 
levado à Península Ibérica, pela expansão do Império Romano, há milênios.

Selecionamos a monografia12 (M12), o caso da MPв na sala-de-aula, onde a historicização da MPB começa pelos primeiros viventes desta terra, inventores de instrumentos musicais chamados toscos, ainda localizados em festas folclóricas. O conhecimento já-produzido na cultura atravessa a catequese dos índios, os primeiros séculos de colonização; cita de toscos a tambores, atabaques, tantãs, palmas, apitos e ainda registra as fanfarras militares dos exércitos portugueses.

Depois, final do século XVIII, e por aí vai passando pelas aulas de violão de Chiquinha Gonzaga em 1870, no Rio de Janeiro, e continua por Orlando Silva, Pixinguinha, Carmem Miranda, Noel Rosa, Braguinha, Mário Lago, Dorival Cayme, Luis Gonzaga, Ângela Maria, Cauby, João Gilberto e, entre outros citados, Roberto Carlos Braga, Caetano Emanuel Viana Telles Veloso e muitos citados depois com seus nomes completos e contextos descritos até Marisa Monte, Arnaldo Antunes, Lobão, Renato Russo, etc.

Da página 31 à página 46, são 16 páginas reservadas à pesquisa, mas mesmo aí não encontramos equilíbrio entre a historicização e a construção do objeto, porque as inferências sobre a necessidade de facilitar a aprendizagem pela inclusão da música na sala de aula são feitas sob a responsabilização do autor-citado. Além disso, entre essas 16 páginas, algumas são de letras de músicas e de roteiros de aula, sem análise, apenas incluídas num roteiro de atividades.

- minimização da pesquisa. O próximo quadro demonstrativo está levando em consideração, nas monografias lidas, itens como assunto; número de páginas que contemplam história ou teoria; número de páginas que contemplam dados da realidade, no caso alguma instituição de ensino e itens como inves- 
tigação ou alguma prática de leitura ou do texto literário ou do texto publicitário, além da aplicabilidade da teoria.

Pretendemos com isso analisar o que há nas produções sobre construção do objeto ou produção do conhecimento e inferimos, pelo que encontramos, que as monografias de conclusão de curso analisadas são constituídas, em sua quase totalidade, de historicização do objeto ou de teorias, ou de conceitos, inferindo também sobre duas possibilidades.

A primeira é a de que, quando os pesquisadores que produziram essas monografias julgaram ter atingido o primeiro momento da teoria, não tendo o que fazer no segundo, o da pesquisa, finalizaram o trabalho depois de poucas páginas, às vezes uma de referência a alguma realidade. A segunda é a de que, como o ensino transmissivo exige a repetição do já-produzido pela cultura, os pesquisadores que produziram essas monografias pensam que um trabalho monográfico de conclusão de curso nada tem com investigação e uma produção na universidade é repetição do já-produzido.

O fato é que, quando se trata de aplicação prática ou de construção do objeto, investigação sobre a realidade, o que existe é extremamente insuficiente para que pensemos em produção do conhecimento, numa relação de 52 páginas para a teoria e 5 para fazer análise de dados; 42 páginas de teoria para 2 sobre algum dado da realidade; 27 de teoria para 1 de pesquisa; 54 de teoria para 1 página de aplicação prática de leitura, como está demonstrado no próximo quadro.

Pudemos ver, em algumas monografias, que essas poucas páginas onde a pesquisa se iniciaria descrevem a escola e ainda colocam fotos, ou prescrevem uma metodologia como sugestão, quer seja de leitura ou de ensino de língua, ou transcrevem textos, poemas, letras de músicas, além das citações que responsabilizam outro locutor para inferir sobre a realidade, inclusive para prescrever sobre o olhar do pesquisador 
que infere sob a prescrição do autor-citado. O que acabamos de dizer está exposto a seguir:

\begin{tabular}{|c|c|c|c|c|c|c|c|c|}
\hline 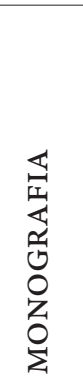 & ANO & PÁG. & ASSUNTO & 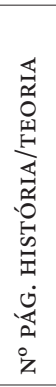 & 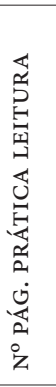 & 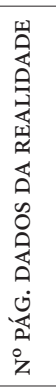 & 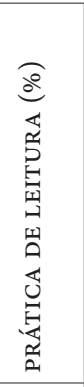 & 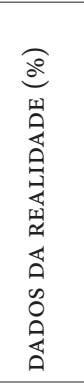 \\
\hline M1 & 2001 & 62 & Ensino de LP & 57 & - & 5 & - & $8 \%$ \\
\hline M2 & 2007 & 43 & Intertextualidade & 34 & 9 & - & $21 \%$ & - \\
\hline M3 & 2007 & 44 & $\begin{array}{c}\text { Aquisição de } \\
\text { linguagem }\end{array}$ & 42 & - & 2 & - & $5 \%$ \\
\hline M4 & 2007 & 44 & Leitura & 31 & 13 & - & $30 \%$ & - \\
\hline M5 & 2008 & 32 & $\begin{array}{c}\text { Inteligência } \\
\text { poética }\end{array}$ & 25 & 7 & - & $22 \%$ & - \\
\hline M6 & 2008 & 28 & Ensino de LP & 27 & - & 1 & - & $4 \%$ \\
\hline M7 & 2002 & 55 & Alfabetização & 54 & 1 & - & $2 \%$ & - \\
\hline M8 & 2006 & 40 & Alfabetização & 38 & - & 2 & - & $5 \%$ \\
\hline M9 & 2004 & 57 & Leitura & 52 & - & 5 & - & $9 \%$ \\
\hline M10 & 2006 & 44 & Leitura & 44 & - & - & - & - \\
\hline M11 & 2004 & 52 & Ensino de LP & 40 & - & 12 & - & $23 \%$ \\
\hline M12 & 2004 & 53 & Ensino de LP & 39 & - & 14 & - & $26 \%$ \\
\hline
\end{tabular}




\begin{tabular}{|c|c|c|c|c|c|c|c|c|}
\hline 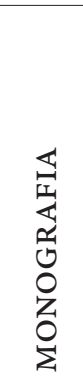 & ANO & PÁG. & ASSUNTO & 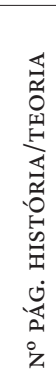 & 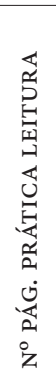 & 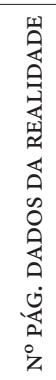 & 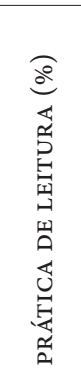 & 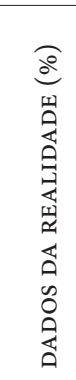 \\
\hline M13 & 2001 & 70 & Escrita & 42 & - & 28 & - & $40 \%$ \\
\hline M14 & 2003 & 46 & Escrita & 31 & - & 15 & - & $33 \%$ \\
\hline M15 & 2006 & 53 & Ensino de LP & 43 & - & 10 & - & $19 \%$ \\
\hline M16 & 2005 & 78 & Leitura & 53 & - & 25 & - & $32 \%$ \\
\hline M17 & 2005 & 48 & Leitura e escrita & 48 & - & - & - & - \\
\hline M18 & 2005 & 32 & $\begin{array}{c}\text { Formação de } \\
\text { leitores }\end{array}$ & 32 & - & - & - & - \\
\hline M19 & 2005 & 54 & Imagem e texto & 37 & 13 & 4 & $24 \%$ & $7 \%$ \\
\hline M2O & 2006 & 43 & $\begin{array}{l}\text { Gêneros } \\
\text { textuais }\end{array}$ & 43 & - & - & 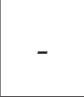 & - \\
\hline
\end{tabular}

- desvio das finalidades. Percebemos, como marca regular da exterioridade determinante das condições de produção na universidade, que o pesquisador se desvia de um pôr teleológico através de uma linguagem conceitual, elimina a construção do objeto como consequência da anulação de todos os nexos próprios à categoria trabalho.

Com isso, limita-se a contar a história do objeto fragmentado ou a relacionar teorias através da história ou a sugerir uma metodologia de leitura ou um modo de dar aula, os 
quais ocupam o lugar da investigação. Significa que, quando o pesquisador se propõe a relacionar MPB a ensino de Língua Portuguesa e se limita a contar a história da MPB; quando ele se propõe a escrever sobre ensino de língua e preenche a maioria das páginas com as teorias, ele ainda está na relação aluno/professor do ensino transmissivo. Os percentuais a seguir expõem a realidade: das 978 páginas lidas, $83 \%$ foram de história ou teoria; $13 \%$ de alguma prática de leitura e $4 \%$ de criação de dados.

Ou seja, as 812 páginas de história e teoria, do total das monografias lidas, contra 123 de prática de leitura e $43 \mathrm{com}$ mais descrição dos dados do que análise, são correspondentes à responsabilização do autor-citado como maior dificuldade enfrentada pelo pesquisador no processo de pesquisa.

Essas ocorrências são compatíveis com a maior incidência de interesse burocrático como eliminação do impulso necessário à pesquisa e com a menor incidência de manifestação da necessidade de produção de conhecimento. Eis um fato que oferece elementos para pensar as condições em que está acontecendo a formação do professor de Língua Portuguesa e a produção de conhecimento na universidade. Talvez seja o momento de começar a repensar a importância do conceito não para ser repetido, mas para servir de ponto de referência a partir do qual se poderá produzir uma impressão de algum objeto o mais distante possível dessa escrita normal orientada pelos manuais de redação. 


\section{Dissertação de mestrado: qual a saída?}


Quando analisamos as dissertações de mestrado, encontramos quase as mesmas categorias de análise já encontradas nas monografias de conclusão de curso. Entretanto, mesmo as que se repetem manifestam nuances particulares no mestrado. A classificação é a seguinte: sobre responsabilização do autorcitado: conjunção normal, conjunção estilizada, titularização do autor, conjunção por justaposição, conjunção por aglutinação, citação enumerada; sobre a construção do objeto: emprego de palavra evasiva, introdução evasiva, conclusão evasiva, historicização do objeto, desvio das finalidades, teoricismo, descrição, avaliação e prescrição. Só que essas características manifestaram nuances discursivas diferentes. Separamos, entre as dissertações lidas e analisadas, as seguintes: 


\begin{tabular}{|c|c|c|}
\hline DISSERTAÇÃO & PUBLICAÇÃo & OBJETO \\
\hline D1 & 2000 & $\begin{array}{c}\text { Formação de professor de } \\
\text { língua portuguesa }\end{array}$ \\
\hline D2 & 2003 & Ensino de produção textual \\
\hline D3 & 2006 & Ensino de produção textual \\
\hline D4 & 2008 & Ensino de leitura \\
\hline D5 & 2008 & Leitura \\
\hline
\end{tabular}

RESPONSABILIZAÇÃO DO AUTOR-CITADO

As marcas da responsabilização de um autor pelo pesquisador acontece, no mestrado, de várias maneiras: pela conjunção normal, marcada por conectivos conformativos; pela justaposição, sem uso do conectivo; pela estilização. Dependendo do modo como a articulação é feita, propomos um tipo de classificação: conjunção normal, conjunção estilizada, titularização do autor, conjunção por justaposição, conjunção por aglutinação, citação enumerada.

- conjunção normal. O que estamos chamando de conjunção normal é aquela articulação mais comum que se dá entre o pesquisador e o autor, através do emprego das conjunções conformativas. Exemplo:

Segundo o autor C, [...]. 
- conjunção estilizada. A conjunção estilizada entre pesquisador e autor-citado já sugere uma certa legitimidade do pesquisador para se sentir mais à vontade no trato com os autores, em função de já estar no plano de qualificação mais elevado. Exemplos:

Bom é lembrar que, para o autor $\mathrm{L}$, texto é sinônimo de prazer. Concateno o meu dizer ao do autor Y, para esclarecer que [...].

— titularização do autor. Nas dissertações, outra forma de citar o autor é colocá-lo no patamar de título de capítulo. Exemplos:

Cap. I - A visão do autor M.

Cap. II - As ideias do autor X.

Cap. III - A dimensão interpretativa de N.

Cap IV - O objeto para Q.

— conjunção por justaposição. Na conjunção por justaposição a articulação se dá por referência, ou por aspas, estando as vozes do autor e do pesquisador em posição paralela. Exemplo:

Essa realidade se dá por uma contradição. "Com todas as intituições, há uma certa diversidade de discursos e linguagens" (A, 1975, p. X X).

- conjunção por aglutinação. Outro tipo de conjunção é o que mistura a voz do autor com a do pesquisador. A esse tipo de conjunção estamos chamando de conjunção por aglutinação. Exemplo:

Essa realidade se dá por uma contradição porque, com todas as instituições, há uma certa diversidade de discursos e linguagens (A, 1975). 
- citação enumerada. A citação enumerada acontece quando, para uma ideia, vários autores são citados. Exemplo:

Esse dado confirma que é preciso que todos os professores sejam leitores (A, 2001; B, 2006; C, 2003; F, 2000).

Nas dissertações de mestrado, há uma alteração na relação do pesquisador com o autor que não elimina a relação de dependência, mas se desloca para um aprofundamento teórico que dificulta a passagem para os dados. Há citações mais longas e uma quase maximização da teoria. $\mathrm{O}$ espaço reservado aos dados se amplia, mas a descrição é predominante pela historicização.

De certa forma, o pesquisador se coloca numa posição mais próxima à do autor, chegando-se mais para perto de uma posição de autoridade, como se, através dessas estilizações, ele estivesse mais autorizado a legitimar outra voz.

\section{A CONSTRUÇÃO DO OBJETO}

- emprego de palavra evasiva. A palavra evasiva selecionada das monografias de conclusão de curso foi "abordagem". No mestrado, a palavra evasiva se distende em expressões evasivas e, ao invés de se posicionar declarando que fará apenas uma abordagem, o pesquisador acrescenta outras possibilidades. Exemplos:

Serão postos em relevo aqui, sem termos a intenção de aprofundamentos, algumas ideias de estudiosos [...].

[...] que a língua seja analisada em seus aspectos mais amplos $[\ldots]$.

Não faremos discussão exaustiva de todas as tipologias [...]. Leque de abordagens feitas nesta dissertação.

Múltiplas dimensões [...].

Conceito muito amplo e complexo com uma infinidade de possibilidade de respostas [...]. 
A palavra abordagem muito presente nas monografias de conclusão de curso cede lugar para outras expressões: concepções teóricas; pressupostos teórico-metodológicos; referencial teórico; metodologia; fundamentos teóricos; conhecimentos necessários.

- introdução evasiva. Assim como nas monografias de conclusão de curso, a introdução evasiva não toca diretamente o objeto. Exemplo:

[...] que os docentes sejam comprometidos com a transformação da sociedade, socializando os conhecimentos necessários [...].

Toda a introdução trata das transformações por que passa a sociedade e não toca no objeto, nem pelo fato de tentar persuadir a necessidade de produzi-lo para ajudar a lidar com essa transformação.

- conclusão evasiva. Pensamos que a conclusão evasiva é reflexo da introdução evasiva. Se, na introdução, a escrita revela uma atitude indefinida diante da pergunta, geralmente no final a resposta será também indefinida. Exemplos:

Toda esta pesquisa acrescenta à noção de língua no ambiente escolar. Não a noção restrita ao código, ao sujeito submisso, mas ao mundo dele que pensa construir, lugar onde é capaz de interagir, de desempenhar a sua função na sociedade enquanto cidadão que sabe enfrentar a vida e é na escola que tudo isso pode acontecer mais efetivamente. O trabalho com textos pode ser feito para revelar cidadãos críticos capazes de fazer sua história. Depois de toda essa pesquisa é necessário continuar pesquisando sobre a teoria $\mathrm{x}$ e sua relação com o conceito $\mathrm{Y}$. 
Depois teremos muitas descobertas que serão importantes para sustentar as nossas “aldeias” teóricas.

- historicização do objeto. Nas dissertações de mestrado, ao contrário das monografias, há mais teoria do que história. A história fica entremeada na teoria e geralmente assume o nome de contextualização ou percurso histórico.

Pudemos observar, neste nível de qualificação, que o teoricismo dificulta o trânsito do pesquisador para os dados. E, quando o pesquisador chega à análise dos dados, normalmente a teoria está pronta e, ao invés de ele criar as categorias coerentes com a teoria, ele procura provar com os dados a veracidade de um conceito. O resultado é a cristalização do objeto nos dados que se dão no máximo à descrição.

Por exemplo: uma dissertação sobre formação de professor sob a ótica de um documento oficial desvia-se da formação do professor com a interferência das orientações oficiais e limita-se a descrever o documento, a historiar outros documentos anteriores e não toca na questão formação do professor, que é o objeto.

- desvio das finalidades. Decidimos quantificar, na dissertação, o número de páginas reservadas à história do objeto ou à teoria selecionada para a fundamentação teórica; o número de páginas reservadas à pesquisa propriamente dita (os dados, o processo metodológico); o número de páginas reservadas à descrição dos dados e o número de páginas para a análise dos dados. Achamos por bem conferir o volume de páginas dos anexos, da bibliografia, das considerações finais. Pensamos que a exposição desses números no próximo quadro é bastante sintomática de como se dá a pesquisa na universidade e se ela chega a produzir conhecimento ou se apenas fica na reprodução. 
Percebemos dentro das finalidades do pesquisador que há uma certa preocupação com o número final de páginas como critério de conceituação. Ou seja, quanto mais páginas tiver uma dissertação, mais ela trará o indicativo de conter uma boa pesquisa.

O desvio das finalidades da pesquisa se dá pelo desvio do objeto que é a redução da possibilidade de produzir conhecimento através da criação de um novo perfil, pela mudança de direção. Por exemplo: uma dissertação sobre políticas de alfabetização restringe as descrições apenas aos métodos de alfabetizar.

De oito capítulos de uma dissertação, as questões reservadas à pesquisa, não exatamente ao objeto, vão aparecer no $5^{\circ}$ capítulo. Pensando que há toda a descrição da pesquisa e que o último capítulo geralmente é reservado para a conclusão, resta um capítulo para apresentar a análise dos dados.

Nas considerações finais, não é raro encontrar conclusões puramente teóricas. Exemplo:

[...] sustentamos a convergência entre a teoria $\mathrm{x}$ e a $\mathrm{y}[\ldots]$.

Até aqui, pudemos observar que, na dissertação, a preocupação com o autor, tal como foi considerada nas monografias, passa a ser denominada preocupação com o referencial teórico. Assim como nas monografias se instala a historicização do objeto, nas dissertações acontece a teoricização dos conceitos.

Se nas monografias a parte reservada à pesquisa marcou a minimização da investigação, nas dissertações esta parte é ampliada, mas em grande medida fica justaposta aos dados descritos, momento de transição bem difícil ao pesquisador nesse nível de qualificação. É o que se pode observar no próximo quadro. 


\begin{tabular}{|c|c|c|c|c|c|c|c|c|}
\hline 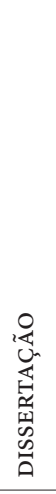 & ANO & PÁG. & ASSUNTO & 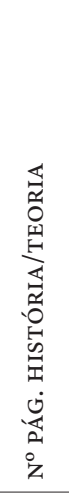 & 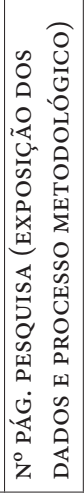 & 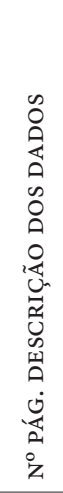 & 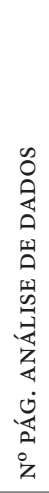 & 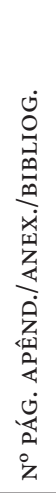 \\
\hline D1 & 2000 & 160 & $\begin{array}{c}\text { Formação de } \\
\text { professor de língua } \\
\text { portuguesa }\end{array}$ & 62 & - & 53 & - & 45 \\
\hline D2 & 2003 & 170 & $\begin{array}{c}\text { Ensino de produção } \\
\text { textual }\end{array}$ & 97 & - & 13 & - & 60 \\
\hline D3 & 2006 & 164 & $\begin{array}{c}\text { Ensino de produção } \\
\text { textual }\end{array}$ & 77 & - & 56 & - & 31 \\
\hline D4 & 2008 & 181 & Ensino de leitura & 77 & - & 85 & - & 19 \\
\hline D5 & 2008 & 120 & Leitura & 52 & - & 60 & - & 8 \\
\hline
\end{tabular}

Levando em consideração que, do total de 795 páginas lidas, 365 foram reservadas para história e teoria, 267 para a pesquisa, ainda restando 163 para a parte burocrática das dissertações, inferimos que neste nível a pesquisa perde a condição de ilustradora da produção, mas ainda reapresenta o legado. 
Abaixo tratamos da classificação de subcategorias que convergem ao desvio das finalidades da pesquisa, não pela minimização da parte reservada aos dados, mas pelo modo de encaminhar a investigação. São as seguintes: teoricismo; descrição, avaliação, prescrição.

- teoricismo. Termos teóricos, clichês, expressões repetidas à exaustão constituem marcas de um teoricismo que se aprofunda no mestrado, não necessariamente do modo como resultaria em novas lentes ao pesquisador para que ele pudesse criar diante dos dados um novo olhar sobre o objeto. Acontece com regularidade muitos casos em que o pesquisador julga a qualidade do dado pelo critério teórico, ou seja, por aquilo que o autor pensa. Exemplos:

Esta forma de escrever é um caso de recategorização anafórica. Segundo o autor x é muito importante essa manobra para a coerência.

Um exercício de argumentação muito importante que deve ser investigado. Isso nos lembra a proposta do autor $\mathrm{x}$ [...]. $\mathrm{O}$ corpus em questão apresenta o conceito do autor $\mathrm{x}$. E é possível reafirmar o que este autor disse: “Os textos são resultado de atividade $\mathrm{v}$ que está sempre em funcionamento no meio social".

- descrição/ avaliação e prescrição. Essas categorias são marcas dos desvios da finalidade da pesquisa. Sem o confronto com o objeto que normalmente se reduz ao corpus, o pesquisador descreve; ao descrever, critica; ao criticar, prescreve e julga. Exemplo:

Recomendamos medidas que não são obrigatórias imperativas para a transformação da realidade escolar. 
O estudo da linguagem não pode ser dissociado da sociedade, porque ela tem natureza social [...].

Desejamos que os professores de LP sejam mais compromissados com a sala de aula [...].

Se a aula de redação for planejada de forma $x,[\ldots]$.

Ficará limitada a [...].

Ficará restrita a $[. .$.$] .$

Ficará prejudicada por $[\ldots]$.

Ficará limitada a [...].

Ficará limitada a [...].

Mas se for planejada de forma $\mathrm{Y},[\ldots]$.

Será beneficiada por [...].

Estará aberta a [...].

Será construída positivamente porque [...].

E será acrescentada por [...].

Saberá $[. .$.$] .$

Saberá [...].

Seja qual for a orientação, o produtor do texto tem que [...].

Dessa maneira, será possível construir uma sala de aula sólida e verdadeira [...].

Nessa perspectiva, deve ser levada em conta a capacidade de ler do professor [...].

Uma sugestão seria uma atividade pedagógica determinada por um currículo que despertasse o aluno a pensar sua história de leitor.

Tudo isso pode orientar as práticas leitoras na escola. Há que se pensar sobre a competência dos promotores de leitura [...].

Os professores da escola pública devem entender a função social da biblioteca pública.

Deve ser incorporada a visão x [...]. No entanto, não se pode fazer isso sem uma metodologia, sem um rumo que possibilite, filosófica ou cientificamente, compreender a educação. 
[...] lamentavelmente, a leitura desse tipo de texto quase não é trabalhada em sala de aula.

É fundamental e necessário que os alunos e alunas leiam diferentes gêneros textuais para que [...].

Deixamos a descrição, a avaliação e a prescrição juntas, porque pensamos que, quando o pesquisador prescreve, ele passa por uma avaliação depois de uma descrição. No exemplo: "[...] lamentavelmente, a leitura desse tipo de texto quase não é trabalhada em sala de aula”, está claro o julgamento no advérbio lamentavelmente. No exemplo: "Dessa maneira, será possível construir uma sala de aula sólida e verdadeira [...], o futuro do presente é um indício de que a sala de aula sólida e verdadeira não existe, ou seja, o que há é uma sala de aula frágil, que não é verdadeira”.

Entretanto, o teoricismo, a estilização da articulação da voz do autor-citado e do pesquisador, a ampliação dos dados são indícios de um discurso qualificado que se autoriza a algumas manobras linguísticas estilizadas que ainda não se mostram suficientes para produzir conhecimento. A análise das teses ampliará esta discussão e estabelecerá uma comparação mais ampliada, de vez que incluirá mais um nível de qualificação. As alterações entre monografias e dissertações são as seguintes: há mais preocupação com a teoria do que com a história do objeto; há também mais ênfase à descrição de dados e à prescrição do que à análise para a criação das categorias e produção de conhecimento.

Estamos considerando desvio das finalidades da pesquisa, porque pensamos que não cabe ao pesquisador dizer como deve ser, mas como está sendo. Com certeza os efeitos serão transformadores, mas na direção não necessariamente traçada pelo pesquisador. 
10. Tese de doutorado: precisamos mesmo da estilização? 
Para analisar as teses selecionadas, mantivemos a mesma classificação utilizada para as monografias e para as dissertações, ou seja, as mesmas categorias de análise, acrescentando neste momento o que não foi encontrado, anteriormente, com significativa regularidade.

\begin{tabular}{|c|c|l|}
\hline TESES & $\begin{array}{c}\text { ANO DE } \\
\text { PUBLICAÇÃO }\end{array}$ & \multicolumn{1}{|c|}{ OBJETO } \\
\hline T1 & 2005 & Leitura \\
\hline T2 & 2008 & Ensino de Português e arte \\
\hline T3 & 2007 & $\begin{array}{l}\text { Ensino de LP sob } \\
\text { parâmetros oficiais }\end{array}$ \\
\hline T4 & 2008 & Metodologia do ensino de LP \\
\hline T5 & 2004 & Produção textual \\
\hline
\end{tabular}


Para a responsabilização do autor-citado, organizamos a seguinte classificação: conjunção normal, conjunção estilizada, titularização do autor, conjunção por justaposição, conjunção por aglutinação, citação enumerada. Sobre a construção do objeto: emprego de palavra evasiva, introdução evasiva, conclusão evasiva, historicização do objeto, desvio das finalidades, teoricismo, estilização, descritivismo, prescritivismo, julgamento. A estilização, por exemplo, que caracteriza as teses não-convencionais, manifesta-se pela narrativização e pela atitude memorialística. Mesmo as categorias que possam parecer repetidas tiveram manifestações diversas.

Por isso, sentimos que seria inevitável avançar aos níveis de análise das produções universitárias da graduação à pósgraduação, comparando-as, se tivéssemos feito uma denominação diferente para cada etapa de qualificação. Nesse caso, perderíamos a possibilidade de estabelecer comparativos. Mas, como o doutorado se autoriza como nível de qualificação mais elevado, tivemos ora que acrescentar, ora que detalhar algumas categorias, ou porque não se manifestaram nas monografias nem nas dissertações, ou porque só apareceram muito sutilmente. Por exemplo: a articulação entre o pesquisador e o autor-citado muda de perspectiva da monografia para a dissertação e desta para a tese, mesmo que revele uma relação de dependência entre ambos.

Temos descoberto que, pelas categorias de análise, tornase possível produzir um novo objeto, ao contrário do conceito que, se confundido com categoria de análise, só levará o pesquisador ao lugar da reprodução teórica e da reapresentação do objeto. $\mathrm{O}$ conceito é a lente que favorece ao pesquisador identificar as características próprias ao objeto e criar-lhe as categorias para analisá-lo. 
As marcas da responsabilização de um autor pelo pesquisador se dão também com nuances diferentes nos três níveis, conforme pudemos observar nas monografias e nas dissertações. No doutorado, a convocação do autor-citado acontece por 6 subcategorias: conjunção normal; conjunção estilizada; titularização do autor; conjunção por justaposição; conjunção por aglutinação; citação enumerada.

- conjunção normal. O que estamos chamando de conjunção normal é aquela articulação mais comum que se dá entre o pesquisador e o autor, através do emprego das conjunções conformativas. Esse tipo de citação ocorre com menor regularidade no doutorado. Exemplo:

Segundo o autor x (1900), texto é [...].

- conjunção estilizada. A conjunção estilizada entre pesquisador e autor-citado marca também uma certa legitimidade do pesquisador para se sentir mais à vontade no trato com os autores, em função de já estar no plano de qualificação mais elevado ainda. Exemplos:

"O ensino de Português", afirma x (2000), "tem sido alvo de políticas governamentais".

Depois, y (1998) reconhece que "não há [...].

Digo que [...]. Dito isso, estou citando y (2008).

Mas intercalar o verbo ou enaltecer um autor ou mesmo citar pode trazer um efeito estilístico que não é suficiente para conferir singularidade à produção. 
- titularização do autor. Tanto nas teses, como nas dissertações, outra forma de citar o autor é colocá-lo no patamar de título de capítulo. Exemplos:

Autor x: a linguagem essencial.

Autor Y: ensino e paixão.

Autor y: o que é o texto?

— conjunção por justaposição. Há conjunção por justaposição quando não é feita nenhuma articulação linguística entre a voz do pesquisador e a do autor, através das conjunções conformativas. A marca são as aspas ou a referência. $O$ fato é que a voz do pesquisador e a do autor ficam paralelas. Exemplo:

Alguns defendem a ideia de que não existe uma escola transformada. É uma "visão ingênua", entretanto. Isso porque esta ideia está sempre relacionada ao âmbito desta pesquisa que trata desse objeto ( $\mathrm{x}, 2009, \mathrm{p} .23)$. É inevitável esquecer que "o texto é [...]" (y, 1999, p. 2), porque a ideia de conjunto fica descartada.

- conjunção por aglutinação. Outro tipo de conjunção é o que mistura a voz do autor com a do pesquisador. A esse tipo de conjunção estamos chamando de conjunção por aglutinação:

As ideias do autor x $(1998,2000)$ sobre Ensino de LP no Brasil têm contribuído para redefinir o lugar $\mathrm{x}$ no processo ensino-aprendizagem, porque ele sugere que a este aspecto seja dada relevância, de vez que [...].

- citação enumerada. A citação enumerada acontece quando, para uma ideia, vários autores são citados. Exemplo: 
Essa ideia está contida em uma das vertentes teóricas da Análise do Discurso que considera z (s, 2001; T, 2003; $\mathrm{x}$, 1999 e $Y, 2008$ ).

Conforme pudemos observar, nas dissertações de mestrado, há uma alteração na relação do pesquisador com o autor que não elimina a relação de dependência. Mas o aprofundamento teórico dificulta a passagem para os dados. $\mathrm{O}$ espaço reservado aos dados se amplia, mas é predominante a descrição de teorias e a historicização. O modo como o autor-citado é convocado nas produções universitárias é indício de como o pesquisador se posiciona frente a essa presença.

No caso das teses, elas manifestaram que o pesquisador, em vez de responsabilizar o autor-citado, em vez de convocar um autor para responsabilizá-lo, tenta transparecer que está implicado juntamente com ele, num processo de apropriação, que vai apenas ao extremo de uma aglutinação, porque existe uma citação marcada.

Entretanto, ainda assim, parece-nos que o pesquisador não suprassume o paradigma, a lente. $\mathrm{O}$ máximo aonde ele comumente chega é à articulação linguística entre a sua voz e a do autor-citado. E esse máximo é a aglutinação. Talvez por isso o modelo de um texto científico dificulte ao pesquisador a possibilidade de persuadir sobre o pôr-de-si naquilo que escreve. $O$ pesquisador se autoriza a concordar com o autor-citado, a lhe dar razão. O mais curioso é que não é comum o pesquisador chegar a tirar a razão do autor.

Encontramos, na verdade, um caso que deixamos aqui registrado como exceção. Percebemos, também nas teses, que os autores são elevados mais comumente à dimensão de título de capítulos. Vários capítulos são batizados com o nome do autor. Isso é um dos indícios de que um discurso qualificado não sustenta a produção do conhecimento. 
Apesar das manobras estilísticas inovadoras empregadas nos diferentes níveis de qualificação, o pesquisador não se desloca o suficiente das ideias do autor-citado para outro lugar, apenas chegando a ele, cujo conceito é geralmente exercitado nos dados. Isso manifesta o fato de que o estilístico não resolve o problema da criança (Barzotto, 2006). Por outro lado, há metáforas, expressões que nos dão indício dessa criança que não escreve se soltar a mão do pai.

São exemplos de metáforas que observamos acompanharem o teórico: trilha, esteira, percurso, caminho. O pesquisador diz mesmo estar indo por uma esteira teórica, pela trilha do autor $\mathrm{x}$, o que confirma a metáfora da manada, diante da qual o vaqueiro ginga bovinamente.

Esclarecemos que a esteira teórica é necessária até o momento em que se dá a suprassunção da lente: o momento em que o pesquisador não olha com os olhos do outro, mas com novas lentes recebidas de uma vertente teórica protagonizada por um autor, e produz conhecimento com os próprios olhos. Talvez seja esse o caso que reflete o momento em que o discípulo precise romper com o mestre. Romper, neste caso, não no sentido de ir contra, mas à conquista da independência do próprio olhar.

\section{A CONSTRUÇÃO DO OBJETO}

Para analisar o lugar do objeto no processo de investigação das produções universitárias, algumas categorias de análise foram acrescentadas e outras tomaram outra dimensão. Com isso, recapitulamos a seguinte classificação, face às características que identificamos com acentuada regularidade: emprego de palavra evasiva, introdução evasiva, conclusão evasiva, historicização do objeto, desvio das finalidades, teoricismo, estilização, descritivismo, prescritivismo, julgamento. Mesmo as que parecem repetidas tiveram manifestações diversas. Mas 
a estilização, bem própria do doutorado, caracteriza as teses não-convencionais.

De cada uma destas características regulares nas teses trataremos a seguir:

- emprego de palavra evasiva. A palavra evasiva vai sendo elevada, desde as dissertações de mestrado, a um grau de termos teóricos que são regulares de uma dissertação para outra, de uma tese para outra, não sendo, entretanto, muitas vezes preenchida por um sentido substancial. Quanto a essas palavras evasivas presentes nas teses, pudemos notar que a palavra abordagem não é tão encontrada no discurso qualificado - nível doutorado - e cede lugar, por exemplo, para reflexão crítica.

A expressão interação verbal é capturada nos dados incessantemente, apesar de em vão, por ser um conceito e não uma categoria de análise.

O termo diálogo, ora trançado com o adjetivo sistemático, ora com o universal, ora com a teoria $\mathrm{X}$ ou $\mathrm{Y}$, vai se repetindo até transformar uma teoria em senso comum.

Da mesma forma, são regulares os seguintes termos: pressupostos teórico-metodológicos, levantamento, perguntas abertas, entrevistas semiestruturadas, referencial teórico, orientação filosófica, pressupostos, aspectos teóricos, fundamentos teóricos, orientação teórica, concepções teóricas, universo pactuante, lugar de sujeitos ativos, universo enunciativo-interacional, questão pontual, perlustrar, eixos explicativos, plurissignificação, complexidade do processo, acepções diversas, complexidade do processo, processo leitor, corpo teórico.

— introdução evasiva. A introdução evasiva é indício do desvio do objeto porque o pesquisador, no início, generaliza a tal ponto que não se dirige ao objeto. Exemplos: 
[...] Pesquisar é uma atitude teórica de constante (1) busca. Algo inacabado e permanente quase aproxima da complexidade que é a vida dos cidadãos. (Frase extraída de uma tese sobre formação de professor).

No meio daquele campo, entre as minhas flores preferidas, (2) uma casa no alto me lembra a escola, lá onde todos os dias a professora Marina me esperava para me ensinar sobre a vida. (Frase extraída de uma tese sobre metodologia do ensino de português).

No mundo de hoje este assunto passou a ser fator de sobrevivência. A língua portuguesa, sendo símbolo nacional de identificação, virou o elemento básico do cidadão pleno e a escola um instrumento importante do processo de aprendizagem da escrita e da leitura na construção da cidadania. Neste contexto, a instituição escolar e o professor precisam seguir parâmetros para a qualidade do ensino. (Frase extraída de uma tese sobre formação de professor).

- conclusão evasiva. O desvio se dá na conclusão evasiva como consequência inevitável da introdução que não pergunta sobre o objeto central da pesquisa. Exemplos:

Necessitamos perceber a presença de gêneros textuais nas escolas do Brasil e no mundo, um dos recursos mais necessários para a leitura e escrita de crianças e adolescente. São atitudes pedagógicas que possibilitam dialogar com o mundo interior e exterior de modo autônomo, crítico e criativo. Dar aula não é fácil e requer todo um preparo teórico e prático, onde poderemos seguir perguntando, questionando sem estarmos perdidos. O importante é queremos nos encontrar levantando a bandeira de educadores comprometidos em fazer um Brasil melhor. 
(Conclusão de uma tese sobre metodologia do ensino de língua portuguesa).

Necessitamos incluir na escola a arte. Precisamos descobrir, precisamos perceber. Devemos, pois,... Poderemos, pois, perguntar o que foi feito da Professora Marina que me esperava todos os dias... (Este tipo de pergunta está no último parágrafo de uma tese sobre aula de português e revela um desvio do objeto - a arte na aula de português - e da linguagem científica que não precisa deixar de ser científica para ser singular).

- historicização do objeto. Encontramos, com regularidade, entre as teses, a historicização do objeto. No decorrer da produção, o pesquisador comete desvios ao teorizar e historicizar fora da medida e da direção. Exemplo:

Faremos a apresentação das fases do ensino da língua portuguesa no Brasil desde o período colonial até os dias atuais.

Neste momento da análise, a historicização do objeto acontece pela história do corpus. Ela é necessária como ponto de referência, mas o pesquisador diante da história expressou desvio das finalidades da pesquisa.

Outro exemplo: se uma tese apresenta uma pesquisa sobre a formação de professor de Língua Portuguesa a partir de um documento oficial, comumente chamado de parâmetro, o pesquisador se atém, em grande parte da pesquisa, a contar a história de outros documentos, para chegar ao documento que toma como dado para historicizá-lo e, nesse historicismo que mescla com a teoria, acaba se desviando do objeto que seria a interferência das políticas na formação do professor que pode ser lida no discurso do documento. 
O documento deixa de ser meio para ser fim. Dá-se a reprodução. O pesquisador se perde ao contar quando o documento foi produzido, por quem e como foi publicado. E não volta para comentar a formação do professor através do discurso próprio do período em que ele foi publicado. Alguns pesquisadores chegam a declarar o seguinte: "Não se pode falar de x sem voltar ao passado recente. O passado ecoa".

Encontramos outro tipo de história própria das narrativas orais também entre os dados. Estou levando em conta este tipo de narrativa como historicização, porque elas se sustentam na realidade dos fatos pesquisados. Por exemplo: uma tese sobre formação de professor-leitor tomou como natureza do processo a literatura infantil e historiou a pesquisa ao sabor das narrativas. Imprimiu um tom literário, mas não chegou à literatura; narrou a vida dos professores e suas relações com os livros; não argumentou sobre a literatura infantil na aula de português e, portanto, não procedeu à análise, ficando na descrição. Contou o processo: as aulas que observou, a reação dos professores, a beleza das histórias e concluiu, perguntando-se onde andaria a primeira professora. Esse contar e descrever foram se misturando com alguns teóricos e conceitos, e reproduziu conhecimento sob o estilo literário.

- desvio das finalidades. É comum observar que o pesquisador se desvia das finalidades que fundam um trabalho de pesquisa objetivado nas produções: monografias, dissertações e teses. Por exemplo: uma tese que investiga a relação entre arte e ensino de português e que se pergunta, no início e no final, sobre a professora cuja casa fica num cenário poético desvia-se inclusive do contexto: o ambiente escolar.

- teoricismo. O teoricismo, que seria a exigência do conceito, mascara a autonomia do pesquisador. O que poderia benefi- 
ciar a produção do conhecimento para a aquisição de novas lentes através do conceito favorável à criação das categorias de análise acaba por favorecer sua cristalização. Esse teoricismo desvia o pesquisador do objeto e coloca a pesquisa a serviço do teórico e não os conceitos a serviço da produção do conhecimento. A preocupação permanece muito mais com o autor do que com o objeto.

Exemplos de termos que marcam o discurso teórico, no nível do doutorado: reflexão crítica, diálogo, pressupostos teórico-metodológicos, levantamento, perguntas abertas, entrevistas semiestruturadas, referencial teórico, orientação filosófica, pressupostos, aspectos teóricos, fundamentos teóricos, orientação teórica, concepções teóricas, universo pactuante, lugar de sujeitos ativos, universo enunciativo-interacional, questão pontual, perlustrar, eixos explicativos, plurissignificação, complexidade do processo, acepções diversas, processo leitor, corpo teórico.

A análise dos dados tem mostrado que esta categoria vai assumindo outras nuances. Se nas monografias há uma redução da pesquisa com prioridade para a história, na dissertação há mais teoria. A pesquisa está mais a serviço da teoria. Na tese, tudo isso se amplia e se acrescenta de estilizações em todos os âmbitos, o que faz com que haja desvio das finalidades.

Neste momento de avaliar o desvio das finalidades, o quadro se divide em dois, em função dos dados. O primeiro leva em conta as produções universitárias convencionais, aquelas que se estruturam argumentativamente. $\mathrm{Ne}$ las, teoria, história e pesquisa são facilmente localizáveis. Entre as convencionais, há algumas que misturam teoria e história, vão aos dados, se deslocam para outro aspecto teórico. Mesmo assim é possível localizar esses elementos que incluímos como partes das produções convencionais. É preciso dizer que, no doutorado, há mais pesquisa que 
nos níveis anteriores, mesmo que também esse aprofundamento metodológico não pareça suficiente para produzir conhecimento.

O total de páginas lidas foi de 1377 , sendo que, para as convencionais, o total foi de 737 e para as não-convencionais, de 640. Tendo em vista que os dados selecionados foram aleatórios, pudemos perceber que as teses não-convencionais são reflexo da estilização em busca da singularidade. Estas representam um percentual expressivo. O próximo quadro foi elaborado a partir de teses convencionais.

\begin{tabular}{|c|c|c|c|c|c|c|c|c|}
\hline TESE & ANO & PÁG & ASSUNTO & 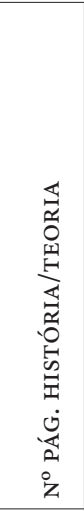 & 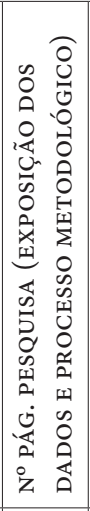 & 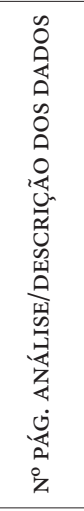 & 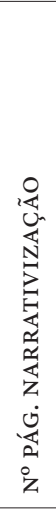 & 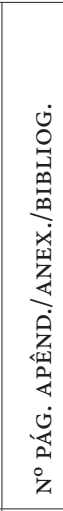 \\
\hline T3 & 2007 & 244 & $\begin{array}{l}\text { Ensino de } \\
\text { LP sob parâme- } \\
\text { tros oficiais }\end{array}$ & 161 & - & 52 & - & 31 \\
\hline $\mathrm{T} 4$ & 2008 & 300 & $\begin{array}{l}\text { Metodologia do } \\
\text { Ensino de LP }\end{array}$ & 140 & - & 115 & - & 5 \\
\hline T5 & 2004 & 193 & $\begin{array}{l}\text { Produção Tex- } \\
\text { tual }\end{array}$ & 140 & - & 17 & - & \\
\hline
\end{tabular}


As teses convencionais - 737 páginas - apresentaram um total de 441 páginas de história e teoria, a teoria muito mais aprofundada que a história; 184 de metodologia da pesquisa, com mais descrição de dados que de análise propriamente dita; e 112 de apêndices, anexos, bibliografia, que estamos considerando a parte burocrática da produção. Por sua vez, é um dado significativo a noção de volume que o legado espera de uma tese e que também não parece interferir na produção de conhecimento. Significa que temos observado, no decorrer das análises, que uma tese de 500 páginas pode não conter nenhuma de produção de conhecimento, apenas de representação de algum objeto já conhecido. O próximo quadro foi elaborado a partir de teses não convencionais.

\begin{tabular}{|c|c|c|c|c|c|c|c|c|}
\hline TESE & ANO & PÁG & ASSUNTO & 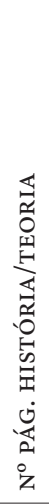 & 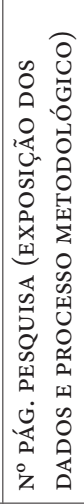 & 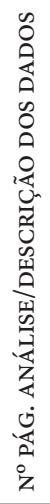 & 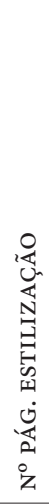 & 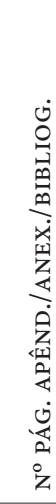 \\
\hline $\mathrm{T} 1$ & 2005 & 303 & Leitura & - & - & - & $\mathrm{x}$ & 8 \\
\hline $\mathrm{T} 2$ & 2008 & 337 & $\begin{array}{l}\text { Ensino de Por- } \\
\text { tuguês e Arte }\end{array}$ & - & - & - & $\mathrm{X}$ & 13 \\
\hline
\end{tabular}

O quadro das teses não convencionais - 640 páginas contém um número reduzido de páginas próprias da burocra- 
cia da pesquisa (5\%), mas o conceito fica diluído por causa da estilização de uma escrita que se nega científica, sem se dar conta de que a linguagem científica em nada impedirá que o conhecimento seja produzido. A linguagem pode permanecer científica. O que vai fazer com que um conhecimento seja produzido e uma produção seja singular é a atitude do pesquisador diante do que o autor diz.

Se o pesquisador não se limitar ao que o autor diz e avançar para o que fazer com o que o autor disse, não estando necessariamente a serviço de uma teoria, haverá uma lógica que fluirá de uma atitude de leitura e resultará numa escrita laborativa. Lembramos que a repetição desmedida do autor-citado impede que o objeto ganhe seus contornos, além de haver referências e conceitos que se diluem.

Sobre as teses não convencionais, outras subcategorias foram acrescentadas para verificar se há ou não produção ou representação do conhecimento. São as seguintes:

- estilização. Estamos chamando de estilização os modos de dizer que insistem num afastamento da linguagem científica e numa aproximação da literária, para buscar um estilo próprio e, com isso, um texto próprio, como se essa atitude possibilitasse produzir conhecimento. A narrativização da pesquisa é um dos recursos da estilização, assim como a atitude memorialística. As teses não convencionais que optaram por esse tipo de escrita dizem textualmente: "Mesmo que o que narro inicialmente nesta tese não esteja na esteira de um diálogo sistemático com o objeto [...]”.

- narrativização. Essa mesma tese de onde extraímos a frase acima, tomada como exemplo de regularidade, restringe as lições da literatura infantil para a história do professor/ informante, narrativizado na tese. Isso acontece quando história, 
teoria e descrição se misturam. Numa tese sobre literatura infantil, os informantes viram personagens, o percurso da pesquisa vira uma história para ser narrada com todas as marcas da oralidade, próprias dos contos de fada e das histórias da literatura infantil. Neste exemplo específico, o pesquisador desabafa assim:

Sempre na direção dos objetivos da minha investigação, o encontro com os alunos vislumbrava uma sala de aula cheia de conflitos. Aula se confundia com reflexão e o mundo ia sendo descoberto e a realidade dos graduandos revelando que têm muita dificuldade para ler e escrever.

Percebemos, no exemplo acima, que vislumbrar é indício de um pesquisador deslocado da pesquisa e o mundo na sala de aula é uma generalização que o pesquisador não recorta. No processo de narrativização, os títulos dos capítulos ficam ao estilo das narrativas. Exemplos:

Capítulo I: O começo [...].

Capítulo II: Os graduando e a escola [...].

Capítulo III: Os informantes, meus personagens.

Capítulo Iv: O Campo teórico no cotidiano escolar.

Capítulo v: Alunos leitores: suas histórias, sua lendas.

Capítulo vi: E a história não termina [...].

Em alguns casos, há um desvio da natureza do objeto e da investigação científica pela natureza da linguagem empregada na tese. A exemplo, extraímos e adaptamos parte da introdução de uma tese sobre a arte na aula de português:

No meio daquele campo florido e bem no alto de um monte avistava uma casa que lembrava a escola em que 
estudei. As manhãs eram de agosto, contornadas por um sol que parecia trazer felicidade. Ah! Minha infância! Tranquilo sol que ia aparecendo para dizer aos poucos que a vida é um desafio. Senti agora vontade de ouvir os pingos da chuva que traziam alguma vontade de sonhar. Era um cenário inesquecível. A metonímia na sala de aula é o objeto desta pesquisa.

A preocupação em estilizar foi tão excessiva que provocou a diluição da natureza do objeto na linguagem da tese.

Percebemos que a tese, por exemplo, sobre a música na sala de aula acaba contaminando o pesquisador do estilo de um compositor. Mesmo que essa linguagem fique ornamentada, ainda assim não é suficiente para que a produção possa ser considerada singular.

Da mesma forma, os títulos dos capítulos, ao estilo das sensações que a melodia desperta, ficaram mais ou menos os seguintes:

Capítulo I: Estudar, cantar e encantar.

Capítulo II: Palavras e sons da natureza na sala de aula.

Capítulo III: Melodias dos textos.

- atitude memorialística. Associados a esse tom, encontramos termos como prazer, musicalidade, imaginantes, cantante, volta ao passado, lembranças dos primeiros anos de escola. A pesquisa vai ficando impregnada de tons subjetivistas. Tudo isso provoca o desvio das finalidades da pesquisa em si e o texto passa a centralizar o processo. Exemplo:

Senti agora vontade de ouvir os pingos da chuva que traziam alguma vontade de sonhar. Era um cenário inesquecível. O assunto y na sala de aula é o objeto desta pesquisa. 
Há uma espécie de enfeite que não acrescenta à produção de conhecimento e resulta na diluição do conceito e comprometimento das categorias para uma pesquisa sem pergunta que começa lembrando a professora Marina e conclui se perguntando onde ela andará. Confrontar introdução e conclusão faz perceber que uma leva à outra. Uma introdução evasiva vai levar, inevitavelmente, a uma conclusão evasiva. Exemplo:

No meio daquele campo, entre as minhas flores preferidas, uma casa no alto me lembra a escola, lá onde todos os dias a professora Marina me esperava para me ensinar sobre a vida. Poderemos, pois perguntar o que foi feito da Professora Marina que me esperava todos os dias...

O desvio das finalidades requer um retorno aos dados para repensar a finalidade não da pesquisa, mas do pesquisador. Se isso se confunde com as necessidades do pesquisador, há um tamponamento da falta necessária que o impulsiona a criar um novo rosto do objeto a partir da possibilidade de contorná-lo através das categorias e não dos conceitos. Essas categorias nascem do objeto refletido e possibilitam ao pesquisador a pesquisa criadora que favorecerá a produção do conhecimento.

Recapitulamos a análise para identificar atitudes que parecem provocar a representação do conhecimento: o teoricismo, pelo aprofundamento teórico que eleva o autor à condição de título de capítulo; o fato de o percentual de páginas reservadas à teoria/história ser superior ao percentual reservado à pesquisa; a regularidade com que as introduções e conclusões são construídas de forma evasiva; o modelo próprio das teses convencionais que favorecem a reapresentação de um objeto já conhecido; a troca de categoria de análise por conceito, ficando a pesquisa a serviço da teoria; a estilização da tese; a 
narrativização da tese; a subjetivação dos dados; a diluição da natureza da linguagem científica pela estilização; a troca de objeto por corpus; o desvio do objeto; a repetição teórica; a reapresentação do objeto.

Trataremos aqui com mais detalhes de três categorias marcantes no discurso qualificado, que já tinham dado seus sinais com menor força nas dissertações:

- o descritivismo. Descrever os dados possibilita ao pesquisador traçar seu perfil. Este ainda se confunde com a historicização, quando se limita ao corpus, sem chegar ao objeto. Exemplos:

Descrição dos dados com fotos [...].

Na escola $\mathrm{x}$, o trabalho com leitura se dá através das seguintes atividades: atividade $\mathrm{x}$ (descrição) bem consequente da atitude de observação presente nos cursos de formação de professor.

A organização $\mathrm{x}$ possui um conselho leitor, constituído de poetas e professores, escolhido pelo público para fazer $\mathrm{X}, \mathrm{Y}$ e $\mathrm{Z}$.

Nessa atividade de leitura, os professores seguem os seguintes passos: primeiro $\mathrm{x}$, depois [...].

- o prescritivismo. Prescrever favorece ao pesquisador ensinar como deve ser. Exemplo:

Não devemos realizar tal tarefa na escola: precisamos ser professores estimuladores, capazes de povoar com atitudes que favoreçam a expressão autônoma.

É fundamental a interação entre sujeito e texto [...].

Os espaços escolares deveriam ser organizados assim: [...].

Às vezes a prescrição está no objetivo da tese: 
Esta tese pretende fornecer elementos para melhorar a formação de professor de português.

- o julgamento. Julgando, o pesquisador avalia o que está certo ou errado. Exemplo:

Os professores deveriam incluir o gênero $\mathrm{x}$ na sala de aula (significa que fazem mal em não incluir).

E às vezes também assume que está julgando. Exemplo:

Foi preciso rever o olhar, fazer um esforço muito grande para não julgar [...]. Mas não posso deixar de fazer uma leitura crítica [...].

Estamos defasados na relação teoria e prática.

O fato de termos criado essas categorias de análise quase conclusivas deve-se à procura incessante da singularidade nas produções universitárias. As marcas que fomos encontrando no decorrer dos episódios e da análise de teses e que, por regularidade, foram sendo criadas na dimensão de produzir a impressão de um discurso, refutaram a cada momento a singularidade, porque, sobretudo as teses, no processo de escrita, pelo fato de irem encontrando saídas estilísticas que desviavam o pesquisador de seu objeto, tamponaram a falta do acesso absoluto ao seu próprio objeto e produziram, por uma escrita normal, a tradução de uma realidade favorável à discussão de um conceito. Estamos considerando essa uma atitude de representação do conhecimento.

Dessa forma, talvez esteja sendo a universidade o espaço não de produção de conhecimento, mas de teoricismos sobre conhecimentos cristalizados e de reapresentações do legado. A impressão dessa escrita favorece este contorno: o do desvio das finalidades do pesquisador nas produções universitárias. 
11. Tudo se cria, nada se copia? 
Depois de termos lido e analisado as monografias de conclusão de curso, as dissertações de mestrado e as teses de doutorado, passamos a tratar as produções universitárias sob dois discursos: o não-qualificado, da graduação, e o discurso qualificado, da pós-graduação. Gostaríamos de deixar claro que qualificado aqui não tem nenhuma relação com qualidade, mas com qualificação no sentido burocrático do termo. Partimos do princípio de que qualificado diz respeito àquele que resulta de alguma qualificação e não estamos entrando no espaço do julgamento, mas nos níveis que se sucedem à graduação.

Esclarecido esse ponto, passamos primeiro a fazer a impressão desse discurso não-qualificado, aquele próprio dos graduandos que ainda não tiveram acesso a nenhum curso de pós-graduação, seja de especialização, mestrado, doutorado ou pós-doutorado. Entre essas marcas, estabelecemos a seguinte classificação:

MONOGRAFIAS - responsabilização do autor-citado [conjunção normal, conjunção estilizada, conjunção por hiperônimo, citação plural, articulação prescritiva]; construção do objeto [emprego de palavra evasiva, introdução evasiva, his- 
toricização do objeto, minimização da pesquisa, desvio das finalidades].

DISSERTAÇÕES - responsabilização do autor-citado [conjunção normal, conjunção estilizada, titularização do autor, conjunção por justaposição, conjunção por aglutinação, citação enumerada]; construção do objeto [emprego de palavra evasiva, introdução evasiva, conclusão evasiva, historicização do objeto, desvio das finalidades, teoricismo, descrição, avaliação e prescrição].

TESES - responsabilização do autor-citado [conjunção normal, conjunção estilizada, titularização do autor, conjunção por justaposição, conjunção por aglutinação, citação enumerada]; construção do objeto [emprego de palavra evasiva, introdução evasiva, conclusão evasiva, historicização do objeto, desvio das finalidades, teoricismo, estilização (narrativização e atitude memorialística), descritivismo, prescritivismo, julgamento].

Classificamos ainda as teses convencionais [escrita normal] e as teses não-convencionais [estilização (narrativização e atitude memorialística)].

Tudo isso levou a ver que a maior importância na escrita do graduando é concedida ao autor como reflexo do ensino transmissivo que, geralmente, não inclui efetivamente a pesquisa, mas a transmissão de um conhecimento cristalizado.

No momento em que o graduando minimiza a investigação, delegando ao objeto a categoria de ilustração, ele tem que supervalorizar a teoria, tal como acontece no processo que ele finaliza: a graduação. Sendo o objeto uma ilustração, haverá um desvio, pois ele não é tratado como alvo. Pensando assim sobre texto, o desvio é do tema. Pensando sobre a produção do conhecimento, o desvio é das finalidades da pesquisa.

A marca mais forte do discurso não-qualificado é a necessidade do autor responsabilizado. E isso acontece de tal maneira que uma das categorias que mais compromete a pro- 
dução do conhecimento é a intitulada responsabilização do autor-citado. Só que essa atitude não foi outra na pós-graduação, mestrado e doutorado. A preocupação com o autor não findou no discurso qualificado. Outras marcas mascaram essa dependência nesses níveis de qualificação.

Para levantar as marcas de um discurso qualificado, também usamos o critério de regularidade e reconhecemos que a exterioridade fornece sua interferência. A necessidade burocrática de qualificação e os modelos facilitadores restringem as produções universitárias à noção de texto. Percebemos, inclusive, que esse parâmetro pode parecer uma certa desvalorização do linguístico. Não é. Talvez passemos por uma supervalorização do linguístico que retorna contra a própria materialidade textual.

Em função disso, percebemos, pelas leituras que fizemos de monografias, dissertações e teses, que as produções universitárias, limitadas à materialidade linguística, sendo uma questão de produção não apenas de texto, mas de conhecimento, trazem os fundamentos textuais comprometidos. Uma introdução evasiva, uma conclusão evasiva, perguntas que não se reportam ao objeto, mas à vida pessoal do pesquisador; a historicização do objeto, o teoricismo, a estilização, a narrativização dos dados, a compatibilização da natureza da linguagem da tese com a do objeto e as demais marcas encontradas desvirtuam não a linguagem científica que parece não impedir que o conhecimento seja produzido, mas os critérios de produção textual.

É nesse nível que esta pesquisa se reencontra com a linha de pesquisa Linguagem e Educação. Os critérios de produção das monografias, dissertações e teses não se restringem à materialidade, porque ela está ferida pela interferência da exterioridade pela qual é convocada e pode ferir a realidade se não se redimensionar. 
Pela regularidade do que encontramos entre as monografias, dissertações de mestrado e teses de doutorado, identificamos como marcas de um discurso qualificado as já presentes no discurso não-qualificado com os acréscimos construídos na análise de dissertações e teses. Diante disso, elaboramos algumas inferências sobre as quais é preciso pensar.

A responsabilização do autor-citado se acentua por uma intimização que acontece na conjunção normal, na estilizada, na conjunção justaposta até o nível da aglutinação entre as vozes do pesquisador e do autor-citado. Mas a dependência do pesquisador não diminui face ao teoricismo aprofundado nesses níveis. Nesse sentido, o pesquisador chega a autorizar-se, inclusive, a intitular capítulos com o nome do autor.

O teoricismo é uma das consequências da intimização e entrelaçamento da voz do autor-citado e do pesquisador, refletindo o deslocamento do pesquisador do seu lugar na pesquisa e um posicionamento equivocado do autor que é fundamental para a continuidade própria da reprodução social. O emprego de palavra evasiva incorpora os termos teóricos que passam a fazer parte de um senso comum universitário.

A introdução e a conclusão evasivas avançam do discurso político da responsabilidade pedagógica pela cidadania, para a estilização poética que cria uma ambiência sugestiva para a tese. De outro modo, a historicização fica entremeada na produção, permanecendo nesse nível sem um lugar específico, podendo se espalhar até o final.

Como consequência, a minimização da investigação é consequência da descrição dos dados, ou seja, dá-se pela representação do conhecimento. $\mathrm{O}$ que há no discurso qualificado é minimização das finalidades, o que bloqueia a produção de conhecimento e impede a singularidade de se manifestar.

Em busca da singularidade impedida, percebemos que o pesquisador, pela necessidade de produzir o texto próprio, 
busca outra saída: a estilização. Para estilizar, ele narrativiza a pesquisa e, pelos desvios que tenta fazer da linguagem científica, perde-se mais ainda do objeto. Compatibiliza a linguagem da produção com a do objeto e cai no vazio, troca objeto por corpus, reapresenta o objeto, desvia-se das finalidades.

No desvio da finalidade principal, que é produzir conhecimento através da construção do objeto, outras saídas são encontradas para tamponar as finalidades com as necessidades: o descritivismo, o prescritivismo e o julgamento.

O descritivismo é regular na análise dos dados que não evolui o suficiente porque o pesquisador pareceu estar sempre descrevendo o corpus na tentativa de confrontar os dados com o conceito, para comprovar as razões do autor.

O prescritivismo é marcado por expressões como é necessário, é fundamental e verbos como devemos, precisamos, não devemos; e pela noção imperativa que, dizendo o que não está acontecendo na escola, diz, ao mesmo tempo e veladamente, o que deveria acontecer.

O julgamento é consequência inevitável de quem descreve e prescreve. Essas duas etapas são atravessadas por um critério de julgamento velado que, dizendo o que o professor deveria saber, está dizendo que ele não sabe.

Voltamos à produção de conhecimento e inferimos que descrever, prescrever e julgar são atitudes que só se dirigem para o que já existe. São atitudes que estão fora do eixo da criação e se dão por um olhar até certo ponto exterior. Essas marcas nos fazem perguntar: na universidade brasileira, tudo se cria, nada se copia?

\section{ESCRITA NORMAL E ESCRITA LABORATIVA}

Conseguimos chegar a uma impressão das produções universitárias criando para isso dois conceitos: o de Escrita Normal e o de Escrita Laborativa. 
Pensamos que a escrita do pesquisador é uma escrita sem-fim quando está processada sob o conceito de trabalho. Aquela produção que circunda o vazio. Sedenta. Curiosa. Questionadora. Uma escrita que vai pondo finalidades. Não necessidades. As finalidades estão nos projetos que envolvem a vida e o sentido de entregar algo que faça o mundo pensar e se transformar. Para isso, ela se contorna do laborativo, das possibilidades de ser livre através da criação, da elaboração. Não é necessariamente o que tem que ser por um julgamento, mas o que é imanente às condições de existência do ser.

As necessidades que contornam a escrita normal são determinadas pelo imediatismo, pelo burocrático, que não se lança à experiência do poço para não perder tempo. Esta escrita apara apenas o suficiente da água que cai ao abrir da torneira.

Este contorno não se encerra porque a impressão, tal como acontece quando se imprime uma figura num tecido da forma mais artesanal possível, leva em consideração não principalmente o texto, mas as atitudes de escrita. Estas atitudes são determinadas ou pelo enfrentamento da falta que gera impulso ao pesquisador, desatando a possibilidade de criar, ou pelo tamponamento favorecido pelo suprimento de necessidades.

Acreditamos ter deixado claro, pelos episódios de pesquisa, que, se a finalidade for de produzir conhecimento, o necessário inferno da escrita, alimentado pela inacessibilidade do real, possibilitará a ciência criadora e, em consequência, a escrita laborativa, condição do novo. Mas, se a necessidade for burocrática, ou seja, de qualificação, por exemplo, com a dimensão pulsional comprometida, o pesquisador se sustentará na escrita normal e, em compensação, dirá, muitas vezes em outro estilo, o que já foi dito. Representará o conhecimento já-produzido aos moldes do ensino transmissivo, visão rotineira de uma universidade repleta de conferências copiadas e repetidas. 
Ora, se a escrita laborativa ainda é rara, não a tendo encontrado nesta garimpagem científica, o mesmo se repete, aos moldes de uma reprodução biológica, e o novo não é encontrado, sendo a singularidade questionável.

Refazendo esta lógica: se o trabalho vivo é a condição do novo da reprodução social; se as produções universitárias, sendo abstraídas, realizam o mesmo; se a condição do novo que não foi garimpado é a singularidade, esta também não poderia ter sido encontrada. E mais: se produzir na universidade não é só uma questão textual, mas uma atitude de escrita laborativa que implica um confronto desafiador como trabalho de produção de conhecimento, escrever não está pronto.

O eterno e incessante retorno para o em-vão do objeto escondido atrás das palavras é a única possibilidade de criar no âmbito das ciências humanas. $\mathrm{O}$ pesquisador que, posto diante de seu objeto de pesquisa, descreve-o sem imprimir dele uma imagem a partir de suas marcas, repete, reproduz ou reapresenta-o. Mas, diante da possibilidade de produzir conhecimento, não vai encontrar outra saída a não ser a de fazer uma impressão, sabendo que as categorias que vê, outros não veriam, e que outros veriam o que ele não vê. É neste ponto que percebemos que as produções universitárias serão tantas quantas forem as impressões delas produzidas se a escrita for laborativa. Pensamos que seja assim o saber humano. Tão incompleto quanto o homem, mas de tão necessária incompletude que é ela que o move para outro lugar.

Tudo aqui resulta de uma luta com o reflexo do objeto construído pelo que se mostrou como ausência. O que apareceu, na maioria das ocorrências, sinalizou para o que não era a singularidade esperada de uma produção pensada sob o conceito de trabalho, mas uma estilização e, muitas vezes, por isso, um desvio. Traçamos, então, a impressão das produções universitárias na busca de produzir algo tal como vestígio 
resultante de pressão sobre um objeto, alguma marca, sinal, efeito produzido, sensação diante do que foi possível separar como atitude do pesquisador movido por suas finalidades e suas necessidades também inconscientes.

A primeira marca com que nos deparamos nas produções universitárias foi a da estilização da conjunção entre o pesquisador e o autor-citado, pelo que percebemos que ligar a voz de ambos por um conforme ou pela elaboração de um dizer similar, através de expressões tais como cito o autor $X$ ou deixo que o autor $Y$ dê sua explicação sobre isso, não é suficiente para que o pesquisador deixe sua quota para a transformação social pela produção do conhecimento.

Sobre o autor-citado, percebemos que ele é, em grande parte, responsabilizado, porque comparece nas produções realizando atos de explicar, de confirmar, de julgar e de inferir, inclusive sobre os dados coletados pelo pesquisador. Em função disso, observamos que o autor tem a responsabilidade de dizer e é também sufocado pelo enunciador coletivo que traz o ponto de vista ideológico, por exemplo, o da necessidade de autor.

Essa voz que precisa de autor é que possibilita ler a exterioridade que determina as condições de produção, lugar onde se fundam as finalidades e necessidades, por exemplo, a de autor-citado.

Essa responsabilização muitas vezes como ponto de partida sinaliza para o distanciamento do pesquisador do processo de objetivação, de realização de uma escrita laborativa que produza efetivamente conhecimento. Esse distanciamento remete para as determinações da exterioridade onde se localizam as condições de produção e para as consequências na produção. Desta produzimos uma impressão com base no conceito de trabalho cujos nexos possibilitam identificar atitudes singulares ou estranhas ao pesquisador. 
E a impressão que esboçamos das produções universitárias que são constituídas, em sua grande parte, de história do objeto fragmentado e de teoria, restando outra parte para a descrição dos dados, confundidos com frequência com o objeto, é a de um documento burocrático exigido por duas instâncias: ora pelo ensino transmissivo, ora pelas políticas educacionais.

Pelo primeiro, o autor-citado é necessário para a responsabilização do dizer; pelo segundo, que contém as consequências do primeiro, o pesquisador, sem os elementos da pesquisa, precisa se qualificar para acesso à carreira, permanência ou ascensão no mercado de trabalho, conferindo aos resultados um alto percentual da manifestação de interesses burocráticos, compatíveis aos interesses relativos à representação do conhecimento e ínfimo com relação ao interesse relativo à pesquisa.

Tanto a primeira quanto a segunda definem condições que produzem necessidades que distanciam o pesquisador da realização de uma produção singular, porque instauram relações próprias de um espaço onde os desafios são movidos por necessidades materiais, imediatas ou burocráticas. Nada mais do que um cenário onde o discurso não é propício à luta do pesquisador com o reflexo do objeto e as atitudes resultantes das escolhas entre alternativas não favorecem a manifestação da singularidade, porque os interesses subjetivos fundantes da pesquisa, na maior parte burocráticos, não são favoráveis à emancipação do pesquisador para que ele chegue a patamares elevados do gênero humano, através do trabalho.

Pelos conceitos a partir dos quais produzimos a impressão das produções na universidade, expomos dois níveis de trabalho com a escrita aos quais já nos referimos. Esses conceitos estão no próximo quadro. 


\begin{tabular}{|c|c|c|c|}
\hline NÍVEL 1: & $\begin{array}{c}\text { ESCRITA } \\
\text { NORMAL }\end{array}$ & $\begin{array}{c}\text { TRADUÇÃO } \\
\text { (o mesmo) }\end{array}$ & $\begin{array}{c}\text { REPRESENTAÇÃO } \\
\text { DONHECIMENTO }\end{array}$ \\
\hline NÍVEL 2: & LABORATIVA & $\begin{array}{c}\text { TRANSLITERAÇÃO } \\
\text { (o nOVO) }\end{array}$ & $\begin{array}{c}\text { PRODUÇÃO DO } \\
\text { CONHECIMENTO }\end{array}$ \\
\hline
\end{tabular}

Para apresentar a impressão a que nos propomos neste momento, voltamos ao que passamos a chamar de escrita normal: a produção universitária consequente de uma visão imobilista.

Criamos este conceito a partir do conceito de ciência normal de Thomas Kuhn (2007). Fizemos uma abstração sobre isso no primeiro capítulo, através de um dado da literatura, onde um pesquisador, em vez de tomar como objeto de estudo o discurso, tenta aprisionar uma fala de seu informante, localizando o dado numa situação imediata e não sócio-histórica, fecha a visão sobre o dado e perde a experiência do movimento como conceito para ampliar sua lente.

O pesquisador aprisionou uma fala, deixou-a como dado, foi teorizar e, quando voltou ao dado, ele não era mais o mesmo. A despeito disso, tentou tornar possível a sua pesquisa pela imobilidade do primeiro momento, ou seja, não se movimentou na construção do processo e provavelmente produziu assim mesmo a sua tese.

A escrita normal, essa que apareceu na análise das produções universitárias, é aquela própria do pesquisador que pensa que o objeto está pronto e, por isso, tenta cristalizá-lo no primeiro olhar dirigido a ele. Localizamos, no âmbito da escrita normal, a consequência inevitável de uma atitude de tradução que "regula a escrita pelo sentido" (Allouch, 1995, p. 16) e representa conhecimento em vez de produzi-lo. 
Já a escrita laborativa, conceito aqui criado a partir da dimensão ontológica do trabalho - a escrita que não apareceu na impressão - pode ser realizada no âmbito da pesquisa, na medida em que o pesquisador se debate no significante pelos efeitos do reflexo cujo conceito permite aceitar que, em qualquer tipo de produção na universidade, haverá sempre algo de ficção, criado pelo olhar do pesquisador que encontra a possibilidade de estar além da materialidade pela transliteração, ou seja, na produção do novo.

Essa escrita laborativa, que exige a produção no campo do conhecimento como atividade de trabalho, depende de uma desestabilização nesse plano, onde as certezas têm que cair e provocar as revoluções de uma dúvida que deve nascer da desconfiança dessas necessidades regulares aqui expostas. Com certeza, a desconfiança de que algo se manifesta na regularidade das finalidades postas pelo pesquisador pode justificar as marcas da exterioridade presentes nessas produções. Marcas de um cenário não propício à manifestação da singularidade.

Pensamos que seja a hora de arriscarmos dizer que pela escrita laborativa, localizamos o lugar fundamental do autor. Sim, ele faz parte da manada e ela não existe sem ele. Mas esse lugar não é exatamente de suas falas, de seus dizeres - para enfeitarem nossos textos. O que eles podem oferecer é muito mais: os conceitos que nos possibilitam a lente para abstrair sobre um objeto que não existe, mas passará a existir através de nossas abstrações. Precisamos não necessariamente de citações, mas de conceitos - eles são utensílios fundamentais para o pesquisador-trabalhador da produção de conhecimento na escrita laborativa. Precisamos, por exemplo, de filosofia para articular linguagem e educação, neste caso particular de pesquisa.

Mas as produções universitárias sinalizam para a exterioridade com as seguintes marcas: o autor-citado silencia a voz 
do pesquisador; o conhecimento produzido na cultura desvia o olhar investigativo; o ensino transmissivo não oferece elementos para a produção do conhecimento, resultando de tudo isso um discurso onde há a minimização do conhecimento produzido.

Diante dos episódios de pesquisa, da análise dos resumos apresentada, da análise das monografias, das dissertações e das teses, das idas e vindas entre a materialidade linguística e a exterioridade, onde se determinam as condições de produção, o pôr das finalidades, a impressão que produzimos das produções universitárias é a de uma escrita normal com marcas de uma exterioridade que interfere negativamente num discurso propício à representação do conhecimento.

Estamos aqui procurando a investigação-sem-fim, porque implica o confronto com a escrita que, não sendo normal, vai desafiar um objeto que insiste em alimentar a falta por nunca se revelar. Será essa a escrita que comumente encontramos quando nos pomos à escuta das vozes dos pesquisadores? Tratar de um objeto já desvelado por um autor tampona o que alimenta a sede de procurar e de se mover para outro lugar, a partir dos lugares já prontos.

A sede que faz dividir a água que escorre de um balde à beira do poço não é de escrever, mas de produzir conhecimento; de construir o objeto. Se o leitor está finalizando sua pesquisa e se sente feliz porque conseguiu o autor que procurava, esteja certo de que não pesquisou; se, ao contrário, encontrou o objeto de investigação em algum lugar e rapidamente o traduziu, também não pesquisou. Se escrever não passou de um ato, não atravessou o deserto, a sede, o sentido da produção, também não atravessou a escrita, espaço de repercussões interiores.

Talvez tudo o que você tenha aí nos seus arquivos seja ainda a matéria prima para sua escrita. Abra todos eles e sem 
olhar para nenhum, comece como quem dança. Em algum momento o objeto vai aparecer.

Nesta investigação, jogamos o balde. Jogamos de novo o balde no fundo do poço, ele só ficou na superfície. Com mais força, ele trouxe um pouco de água, mais um pouco que veio derramando. Aí apareceu alguma atitude, um conceito de ciência normal, outros conceitos, necessidades imediatas do pesquisador, a escrita normal. As finalidades, o trabalho, os contextos da escrita laborativa.

Mas antes, na falta da escrita laborativa que procuramos, apareceu a escrita normal. E isso nos anima a saber que as nossas investigações abrem espaço para o desejo. Desejo de laborar na página, de entrar num processo de escrita: lugar de produção de conhecimento. 


\section{REFERÊNCIAS}

ALLOUCH, Jean. Letra a letra: Transcrever, traduzir, transliterar. Tradução de Dulce Duque Estrada. Rio de Janeiro: Campo Matêmico, 1995.

ALTHUSSER, Louis. Ideologia e aparelhos ideológicos do estado. In: ZIZEK, Slavoj (Org.) Um mapa da ideologia. Tradução de Vera Ribeiro. Rio de Janeiro: Contraponto, 1996. p. 105-142.

ANAIS eletrônicos... Disponível em: <http://www.proceedings. scielo.br/scielo.php?script=sci_arttext\&pid=msc000000003 2006000100012\&lng=pt\&nrm=abn>. Acesso em: 16 mai. 2009.

ANTUNES, Ricardo. Os sentidos do trabalho: ensaio sobre a afirmação e a negação do trabalho. São Paulo: Boitempo Editorial, 2007. (Coleção Mundo do Trabalho).

BARBOSA, Marinalva Vieira. Impasses entre teoria e prática na formação do professor de língua materna. In: BARZOTTO, Valdir Heitor (Org.). Leitura e produção no ensino superior. Inédito.

BARZOTTO, Valdir Heitor. A criança falada e a cena de quem a fala. In: COLÓQUIO DO LEPSI IP/FE-USP, 5, 2006, São Paulo. ; RIOLFI, Claudia Rosa (Orgs.). O inferno da escrita. Campinas: Mercado de Letras, 2011.

BENVENISTE, Émile. Problemas de linguística geral I. Tradução de Eduardo Guimarães et al. Campinas: Pontes, 1988.

CINTRA, Anna Maria Marques. Discutindo apropriação de informações e autonomia de linguagem de pós-graduandos. In: BARZOTTO, Valdir Heitor (Org.). Leitura e produção no ensino superior. Inédito. 
COUTINHO, Carlos Nelson. Lukács, a ontologia e a política. In: ANTUNES, Ricardo; RÊGO, Walquiria Leão (Orgs.). Luckás, um Galileu no séc. XX. São Paulo: Boitempo, 1996. p. 16-26.

DUCROT, Oswald. Esboço de uma teoria polifônica da enunciação. In: - O dizer e o dito. Tradução de Eduardo Guimarães. Campinas: Pontes, 1987. p. 161-222.

DUFOUR, Dany-Robert. A arte de reduzir cabeças: a nova servidão na sociedade ultraliberal. Tradução de Sandra Regina Felqueiras. Rio de Janeiro: Companhia de Freud Editora, 2005. DUBOIS, Jean et al. Dicionário de linguística. Direção e coordenação geral da tradução de Izidoro Blikstein. São Paulo: Cultrix, 1993.

GHIRALDELO, Claudete Moreno. O ensino/aprendizagem de língua portuguesa em cursos de ciências exatas: um espaço de criação. In: BARZOTTO, Heitor Valdir (Org.). Leitura e produção no ensino superior. Inédito.

GRIGOLETTO, Marisa. Do temor do texto ao texto próprio: desafios ao estudo da linguagem. In: BARZOTTO, Valdir Heitor (Org.). Leitura e produção no ensino superior. Inédito.

GUESPIN, L. Types de discours ou functionnements discursifs? Langages, Paris, n. 41, p. 3-11, mar. 1976.

GUIMARÃES ROSA, João. Sagarana. 31. ed. Rio de Janeiro: Nova Fronteira, 1984.

INDURSKY, Freda. O texto nos estudos da linguagem: especificidades e limites. In: ORLANDI, Eni P.; LAGAZZI-RODRIGUES, Suzy (Orgs.). Discurso e textualidade. Campinas: Pontes, 2006. p. 33-80. 
JAPIASSÚ, Hilton; MARCONDES, Danilo. Dicionário básico de filosofia. 3. ed. São Paulo: Jorge Zahar, 1996.

KAUFMANN, Pierre. Dicionário de psicanálise: o legado de Freud e Lacan. Tradução de Vera Ribeiro et al. Rio de Janeiro: Jorge Zahar, 1996.

KUHN, Thomas S. A estrutura das revoluções científicas. Tradução de Beatriz Vianna Boeira e Nelson Boeira. São Paulo: Perspectiva, 2007.

LACAN, Jacques. O Seminário sobre "A carta roubada". In: . Escritos. Tradução de Vera Ribeiro. Rio de Janeiro: Jorge Zahar, 1998a. [1956]. p. 13-66.

. O Seminário. Livro 11. Os quatro conceitos fundamentais da psicanálise. Tradução de M. D. Magno. Rio de Janeiro: Jorge Zahar, 1998b. [1964].

- O Seminário. Livro 17. O avesso da psicanálise. Tradução de Ary Roitman. Rio de Janeiro: Jorge Zahar, 1992. [1969-1970].

LEITE, José A. A. Metodologia de elaboração de teses. São Paulo: Mcgraw-Hill do Brasil, 1978.

LESSA, Sérgio. A ontologia de Lukács. Maceió: EDUFAL, 1996. . Sociabilidade e individuação. Maceió: EDUFAL, 1995.

LISPECTOR, Clarice. Um sopro de vida. 9. ed. São Paulo: Francisco Alves, 1991.

LOPES, Adna de Almeida. Singularidade e escrita no ensino Superior. In: BARZOTTO, Valdir Heitor (Org.). Leitura e produção no ensino superior. Inédito.

LUKÁCS, György. Per l'Ontologia dell'Essere Sociale. Roma: Riunit, 1981. 
- Prolegômenos para uma ontologia do ser social: questões de princípios para uma ontologia hoje tornada possível. Traduzido por Lya Luft e Rodnei Nascimento. São Paulo: Boitempo, 2010.

MORAES, Jomar. Poesia prosa escolhidas de Gonçalves Dias e Machado de Assis. São Luís: EDUFMA, 1997.

ORLANDI, Eni P. Discurso, imaginário, social e conhecimento. Em Aberto, Brasília, ano 14, n. 61, p. 53-59, jan./mar., 1994.

PESQUISADORES e Projetos. Grupos de Estudos e Pesquisa Produção Escrita e Psicanálise - GEPPEP. Movimentos do Escrito. Disponível em: <http://paje.fe.usp.br/ geppep/site. htm>. Acesso em: 20 mar. de 2009.

PÊCHEUX, Michel. Análise automática do discurso (AAD-69). In: GADET, Francisco; HAK, Tony (Orgs.). Por uma análise automática do discurso: uma introdução à obra de Michel Pêcheux. Campinas, SP: Editora da UNICAMP, 1990a. [1969]. p. 61-162.

O discurso: estrutura ou acontecimento. Tradução de Eni Pulcinelli Orlandi. Campinas: Pontes, 1990b. [1983].

. Semântica e discurso: uma crítica à afirmação do óbvio. Tradução de Eni Pulcinelli Orlandi et al. 3. ed. Campinas: UNICAMP, 1997.

REY, Luís. Planejar e redigir trabalhos científicos. 2. ed. São Paulo: Editora Edgard Blucher, 1993.

RIOLFI, Claudia Rosa. Leitura: ação da pesquisa na formação. Revista Linguas e Letras (UNIOESTE), Cascavel - PR, v. 2, n. 1 , p. $13-18,1^{\circ}$ semestre 2001.

- Pesquisa-dor... Grupos de Estudos e Pesquisa Produção Escrita e Psicanálise - GEPPEP. Disponível em: 
$<$ http://paje.fe.usp.br/ geppep/mainframe02.htm>. Acesso em: 20 mar. 2009.

ROSSI-LANDI, Ferruccio. A linguagem como trabalho e como mercado. Tradução de Aurora Fornoni Bernardini. São Paulo: DIFEL, 1985.

SABOIA, Beatriz. A construção da lógica dialética em Hegel. São Luís: EDUFMA, 2001.

SANTOS, Clóvis Roberto dos; NORONHA, Rogéria Toler da Silva de. Monografias Científicas: TCC, Dissertação, Tese. São Paulo: Avercamp, 2005.

SAUSSURE, Ferdinand. Curso de linguística geral. São Paulo: Cultrix, 1998.

SEVERINO, Antônio Joaquim. Metodologia do trabalho científico. 23. ed. rev. e atual. São Paulo: Cortez, 2007.

. Ensino superior: lugar da escrita e da produção do conhecimento. In: BARZOTTO, Valdir Heitor (Org.). Leitura e produção no ensino superior. Inédito.

SOARES, Maria das Graças. A formação inicial do professor de língua portuguesa frente a exigências da sala de aula. In: BARZOTTO, Valdir Heitor (Org.). Leitura e produção no ensino superior. Inédito.

VELOSO, Caetano. Vaca Profana. In: . Totalmente Demais ao vivo. São Paulo: Polygram, 1986. 1 disco sonoro. Lado b, faixa 1. WARDE, Mirian Jorge. A favor da educação, contra a positivização da Filosofia. Em aberto, Brasília, ano 9, n. 45, p. 27-33, jan./ mar. 1990.

WEINRICH, H. Le temps. Paris: Seuil, 1973.

ZIZEK, Slavoj. O mais sublime dos histéricos: Hegel com Lacan. Tradução de Vera Ribeiro. Rio de Janeiro: Jorge Zahar, 1991. 


\section{BIBLIOGRAFIA COMPLEMENTAR}

ABBAGNAMO, Nicola. Dicionário de Filosofia. Coordenação por Alfredo Bosi. São Paulo: Martins Fontes, 2000.

ANTUNES, Ricardo; RÊGO, Walquiria Leão (Orgs.). Lukács: um Galileu no século XX. São Paulo: Boitempo, 1996.

BARZOTTO, Valdir Heitor (Org.). Estado de Leitura. Campinas: Mercado das Letras: Associação de Leitura do Brasil, 1999. (Coleção Leituras no Brasil).

. Leitura e produção de texto: limites e relações intersubjetivas. In: CALIL, Eduardo (Org.). Trilhas da escrita: autoria, leitura e ensino. São Paulo: Cortez, 2007, p. 159-170. V. 1

BENVENISTE, Émile. Problemas de linguística geral II. Tradução de Eduardo Guimarães et al. Campinas: Pontes, 1989.

CARDOSO, Silvia Helena Barbi. Discurso e ensino. Belo Horizonte: Autêntica, 1999.

CERTEAU, Michel de. A invenção do cotidiano: 1. Artes de fazer. Tradução de Ephraim Ferreira Alves. Petrópolis: Vozes, 1994.

DIONÍSIO, Angela Paiva; MACHADO, Ana Rachel; BEZERRA, Maria Auxiliadora (Orgs.). Gêneros textuais e ensino. 3. ed. Rio de Janeiro: Lucerna, 2005.

DUCROT, Oswald. Princípios de semântica lingüística. Dizer e não dizer. Tradução de Carlos Vogt, Rodolfo Ilari e Rosa Attié Figueira. São Paulo: Cultrix, 1972.

FIORIN, José Luiz. As astúcias da enunciação: as categorias de pessoa, espaço e tempo. 2. ed. São Paulo: Ática, 1999.

FLORES, Valdir; TEXEIRA, Marlene. Introdução à linguística da enunciação. São Paulo: Contexto, 2008. 
FOUCAULT, Michel. A ordem do discurso. Tradução de Laura Fraga de Almeida Sampaio. São Paulo: Edições Loyola, 2003. . A arqueologia do saber. Tradução de Luiz Felipe Baeta Neves. 5. ed. Rio de Janeiro: Forense Universitária, 2000.

FREUD, Sigmund. Os instintos e suas vicissitudes. In: Edição Standart Brasileira das Obras Psicológicas Completas de Sigmund Freud. Rio de Janeiro: Imago, 1976 [1915]. V. 14.

GÉRARD, Pommier. Nacimiento y renacimiento de la escritura. Buenos Aires: Nueva Visión, 1993.

GINZBURG, Carlo. O queijo e os vermes: o cotidiano e as idéias de um moleiro perseguido pela Inquisição. Tradução de Maria Betânia Amoroso. São Paulo: Companhia das Letras, 1987.

- Mitos, emblemas e sinais: morfologia e história. Tradução de Frederico Carotti. São Paulo: Companhia das Letras, 1989.

GREGOLIN, Maria do Rosário; BARONAS, Roberto (Orgs.). Análise do discurso: as materialidades do sentido. 2. ed. São Carlos: Claraluz, 2003.

HEGEL, Georg Wilhelm Friedrich. Ciencia de la lógica. 2. ed. Buenos Aires: Solar, 1968.

. Fenomenologia do espírito. Tradução de Paulo Meneses. 4. ed. Florianópolis: Vozes; Bragança Paulista: Editora Universitária São Francisco, 2002.

INDURSKY, Freda. Relatório Pinotti: o jogo polifônico das representações no ato de argumentar. In: GUIMARÃES, Eduardo (Org.). História e sentido na linguagem. Campinas: RG, 2008. p. 93-128. 
INWOOD, Michael. Dicionário Hegel. Tradução de Álvaro Cabral. São Paulo: Jorge Zahar, 1997.

JAKOBSON, Roman. Linguística e comunicação. Tradução de Izidoro Blikstein e J.P.Paes. São Paulo: Cultrix, 1969.

LACAN, Jacques. O Seminário. Livro 10. A angústia. Tradução de Vera Ribeiro. Rio de Janeiro: Jorge Zahar, 2005.

. O Seminário. Livro 23. O Sinthoma. Tradução de Sérgio Laia. Rio de Janeiro: Jorge Zahar, 2007.

LESSA, Sérgio. Trabalho e ser social. Maceió: EDUFC/ EDUFAL, 1997.

LUKÁCS, György. Ontologia do ser social: os princípios ontológicos fundamentais de Marx. Tradução de Carlos Nelson Coutinho. São Paulo: Livraria Editora Ciências Humanas, 1979.

. Ontologia do ser social: a falsa e a verdadeira ontologia de Hegel. Tradução de Carlos Nelson Coutinho. São Paulo: Livraria Editora Ciências Humanas, 1979.

MARIANI, Bethania (Org.). A escrita e os escritos: reflexões em análise do discurso e psicanálise. São Carlos: Claraluz, 2006.

MOLES, Abraham A. As ciências do impreciso. Colaboração de Elisabeth Rohmer. Tradução de Glória de C. Lins. Rio de Janeiro: Civilização brasileira, 1995.

ORLANDI, Eni P. Discurso e leitura. São Paulo: Cortez; Campinas: UNICAMP, 1988.

(Org.). Gestos de leitura: da história no discurso. Campinas: UNICAMP, 1994.

; LAGAZZI-RODRIGUES, Suzy (Orgs.). Discurso e textualidade. Campinas-SP: Pontes, 2006. 
PAVEAU, Marie-Anne; SARFATI, Georges-Élia. As grandes teorias da linguística: da gramática comparada à pragmática. Tradução de Rosário Gregolin (Coord.) et al. São Carlos: Claraluz, 2006.

PÊCHEUX, Michel. O discurso: estrutura ou acontecimento. Tradução de Eni Pulcinelli Orlandi. Campinas: Pontes, 1990.

PINASSI, Maria Orlanda; LESSA, Sérgio. Lukács e a atualidade. São Paulo: Boitempo, 2002.

POMMIER, Gerard. Naissance et renessance de lécriture. Tradução de Cristine Marie Tedeschi Conforti. Paris: Presses Universitaires de France, 1993.

PORTO, Célia. Método: Lukács e Althusser. In: LESSA, Sérgio (Org.). Habermas e Lukács: método, trabalho e objetividade. Maceió: EDUFAL, 1996, p. 29-44.

POSSENTI, Sírio. Discurso, estilo e subjetividade. São Paulo: Martins Fontes, 1988.

REGO, Claudia de Moraes. Traço, letra, escrita: Freud, Derrida, Lacan. Rio de Janeiro: Letras, 2006.

REZENDE, Letícia Marcondes; ONOFRE, Marília Blundi (Orgs.). Linguagem e línguas naturais: diversidades experiencial e linguística. São Carlos: Pedro \& João Editores, 2006.

RIOLFI, C. R. Quebras na escrita, surpresas para quem escreve: o percurso subjetivo na formação do professor de Língua Portuguesa. In: CALIL, Eduardo (Org.). Trilhas da escrita: autoria, leitura e ensino. São Paulo: Cortez, 2007, p. 33-64.

. O discurso que sustenta a prática pedagógica: formação de professor de língua materna. 1999. Tese (Doutorado em Linguística). Instituto de Estudos da Linguagem, Universidade Estadual de Campinas, Campinas, 1999. 
SABOIA, Beatriz. Lukács e a centralidade ontológica da categoria trabalho. Serviço Social e Movimento Social, São Luís, EDUFMA, v. 1, n. 1, p. 77-85, jul./dez. 1999.

SAFATLE, Valdimir Pinheiro. A paixão do negativo: Lacan e a dialética. São Paulo: UNESP, 2006.

SANTOS, Boaventura. Um discurso sobre as ciências. 12. ed. Porto: Edições Apontamentos, 2001. 
Livro composto na tipologia Minion Pro, corpo $12 / 14,4$; miolo em papel offset $90 \mathrm{~g} / \mathrm{m}^{2}$ e capa em cartão supremo $250 \mathrm{~g} / \mathrm{m}^{2}$ 